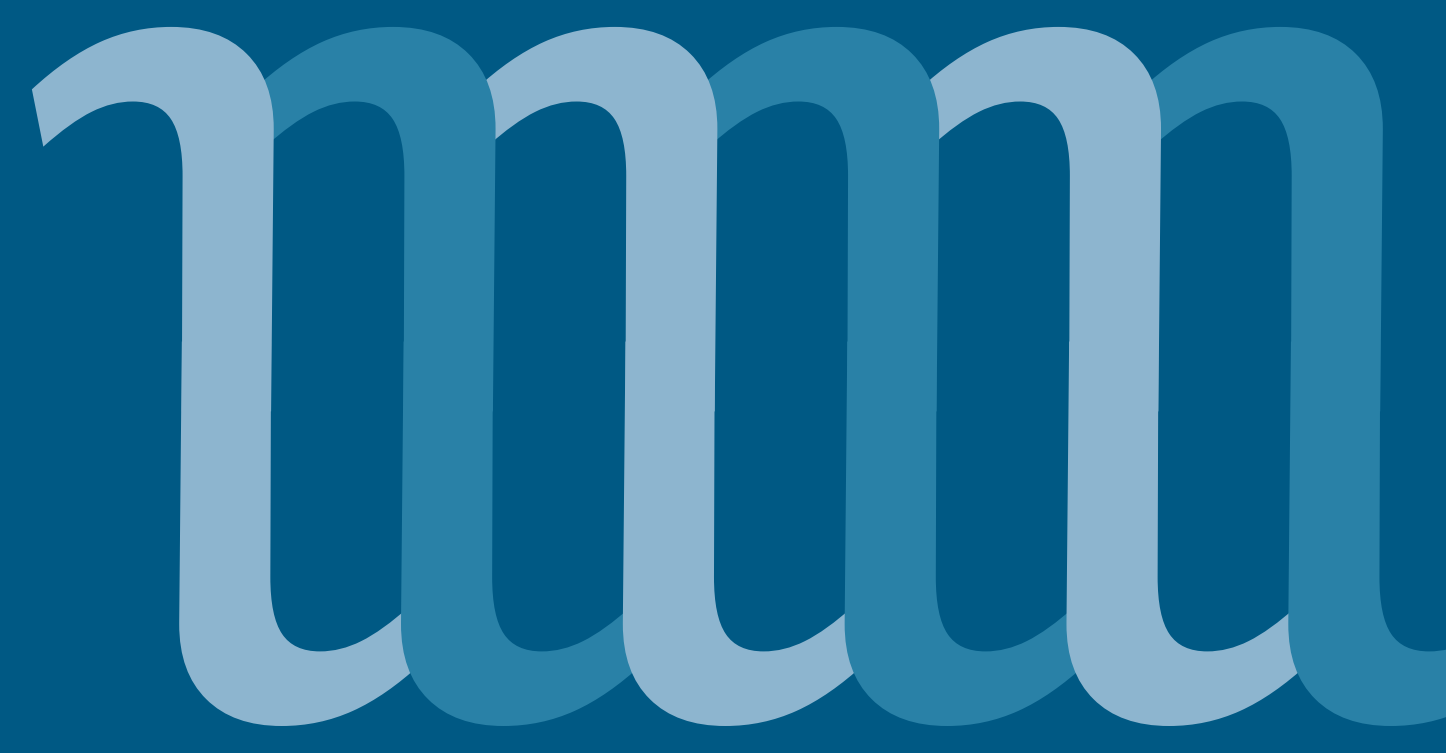

\title{
Digitalna pismenost srednješolcev
}

Sašo Stanojev

Viktorija Florjančič

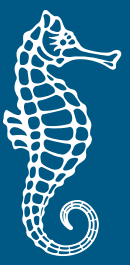


Znanstvene monografije

Fakultete za management

Glavni urednik

Matjaž Novak

Uredniški odbor

Ana Arzenšek

Štefan Bojnec

Dubravka Celinšek

Armand Faganel

Viktorija Florjančič

Borut Kodrič

Suzana Laporšek

Mirko Markič

Franko Milost

Matjaž Nahtigal

Mitja Ruzzier

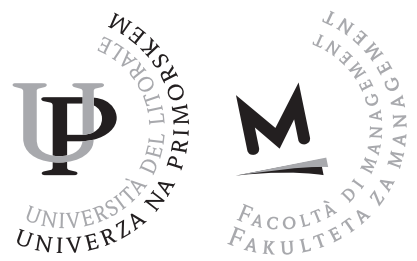




\section{Digitalna pismenost srednješolcev}

Sašo Stanojev

Viktorija Florjančič

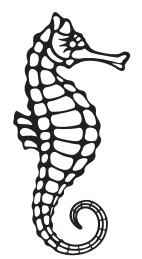


Digitalna pismenost srednješolcev

Sašo Stanojev

Viktorija Florjančič

Recenzenta · Dušan Lesjak in Nada Trunk Širca

Lektoriranje · Davorin Dukić

Oblikovanje in tehnična ureditev · Alen Ježovnik

Izdala in založila $\cdot$ Založba Univerze na Primorskem

Titov trg 4, 6ooo Koper

www.hippocampus.si

Glavni urednik · Jonatan Vinkler

Vodja založbe · Alen Ježovnik

Koper, januar 2018

(C) 2018 Sašo Stanojev in Viktorija Florjančič

http://www.hippocampus.si/ISBN/978-961-7023-78-7.pdf

http://www.hippocampus.si/ISBN/978-961-7023-79-4/index.html

https://doi.org/10.26493/978-961-7023-78-7

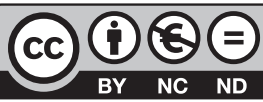

Kataložni zapis o publikaciji (CIP) pripravili

$\mathrm{v}$ Narodni in univerzitetni knjižnici v Ljubljani

COBISS.SI-ID $=293934592$

IS B N 978-961-7023-78-7 (pdf)

IS B N 978-961-7023-79-4 (html) 


\section{Kazalo}

Seznam preglednic $\cdot 6$

Seznam slik $\cdot 7$

$1 \mathrm{Uvod} \cdot 9$

2 Informacijsko-komunikacijska tehnologija in digitalna pismenost · 15

2.1 Opredelitev osnovnih pojmov $\cdot 15$

2.2 Pobude in projekti za spodbujanje razvoja digitalne pismenosti 20

3 Modeli merjenja digitalne pismenosti $\cdot 37$

3.1 Model merjenja digitalne pismenosti DCA $\cdot 37$

3.2 Razvoj modela DCA 37

3.3 Model merjenja digitalne pismenosti DIGCOMP $\cdot 43$

3.4 Model merjenja računalniške in informacijske pismenosti ICILS · 46

4 Šolski sistem in gimnazija v sistemu vzgoje in izobraževanja 53

4.1 Srednješolsko izobraževanje v Sloveniji 53

4.2 Posodobitev gimnazijskih programov $\cdot 55$

4.3 Digitalna pismenost v prenovljenih programih $\cdot 59$

4.4 Vključevanje tehnologije v učenje in poučevanje $\cdot 63$

4.5 IKT in učenje - rezultati raziskave PISA $2012 \cdot 64$

4.6 Informatizacija slovenskih šol in projekt Računalniško opismenjevanje $\cdot 67$

4.7 E-kompetentna šola - projekt E-šolstvo 69

5 Raziskava digitalne pismenosti $\cdot 73$

5.1 Metodologija zbiranja in obdelave podatkov $\cdot 73$

5.2 Predstavitev vzorca $\cdot 74$

5.3 Analiza podatkov o digitalni pismenosti $\cdot 78$

5.4 Preverjanje hipotez $\cdot 82$

5.5 Primerjava skupnih rezultatov z raziskavo digitalne pismenosti $\mathrm{v}$ Italiji $\cdot 89$

6 Sklepna razmišljanja $\cdot 93$

Literatura $\cdot 97$

Priloge $\cdot 103$ 


\section{Seznam preglednic}

2.1 Primerjava preučevanih okvirov digitalne pismenosti $\cdot 21$

2.2 Okvir digitalne pismenosti NCCA 33

2.3 UNESCO matrika IKT pismenosti učiteljev $\cdot 35$

3.1 Naloge tehnološke dimenzije okvira D CA $\cdot 41$

3.2 Naloge kognitivne dimenzije okvira DCA $\cdot 42$

3.3 Naloge etične dimenzije okvira D CA $\cdot 42$

4.1 Moduli izobraževanja e-kompetentnega ravnatelja $\cdot 71$

4.2 Rezultati projekta E-šolstvo (v številkah) 71

5.1 Struktura anketirancev po geografskih regijah $\cdot 74$

5.2 Aktivnosti dijakov na internetu $\cdot 77$

5.3 Načini pridobivanja ali raven znanja s področja I K T 77

5.4 Uporaba I K T pri delu v šoli $\cdot 78$

$5 \cdot 5$ Število predmetov, kjer uporabljajo I K T $\cdot 78$

5.6 Porazdelitev skupnih rezultatov merjenja digitalne pismenosti 79

5.7 Digitalna pismenost glede na demografske značilnosti $\cdot 80$

5.8 Digitalna pismenost glede na način pridobivanja znanja in pogostost rabe IK T $\cdot 81$

5.9 Doseženi rezultati znanj in veščin po modelu DCA $\cdot 82$

5.10 Preverjanje normalnosti porazdelitve spremenljivke $\cdot 84$

5.11 Povprečni rang za spremenljivke dimenzije digitalne pismenosti $\cdot 84$

5.12 Testne statistike za spremenljivko Vrste gimnazijskega programa 85

5.13 Preverjanje normalnosti porazdelitve za spremenljivko Spol $\cdot 86$

5.14 Povprečni rang za spremenljivko Spol $\cdot 86$

5.15 Testne statistike za spremenljivko Spol $\cdot 86$

5.16 Preverjanje normalnosti porazdelitve spremenljivke Regija $\cdot 87$

5.17 Povprečni rang za spremenljivko Regija $\cdot 87$

5.18 Testne statistike za spremenljivko Regija $\cdot 88$

5.19 Medsebojna povezanost spremenljivk digitalne pismenosti $\cdot 88$

5.20 Primerjava porazdelitev skupnih rezultatov raziskav $\cdot 90$

5.21 Povprečni rezultati po dimenzijah digitalne pismenosti · 90 


\section{Seznam slik}

2.1 Ravni znanja po modelu digitalne pismenosti ACT IC $\cdot 22$

2.2 Veščine digitalne pismenosti po modelu BECTA $\cdot 23$

2.3 Ravni digitalne pismenosti po modelu DigEuLit · 25

2.4 Konceptualni okvir digitalne pismenosti Eshet-Alkalai · 30

3.1 Okvir digitalne pismenosti DCA 39

5.1 Vrste naprav za povezovanje $\mathrm{z}$ internetom $\cdot 75$

5.2 Naprave za najpogostejši dostop do interneta $\cdot 76$

5.3 Povprečna uspešnost dijakov po posameznih dimenzijah $\cdot 79$ 



\section{Uvod}

Generacija mladih, ki prihaja v izobraževalni sistem ali pa je vanj že vključena, je rojena v času sodobne informacijsko-komunikacijske tehnologije (I K T). Gre za generacijo, ki jo strokovnjaki opisujejo kot digitalne domorodce (Prensky 2001), »milenijce« (Howe in Strauss 2009), "net generacijo (Oblinger in Oblinger 2005) ali »homo zappiense« (Veen in Vrakking 2006). Ta generacija je izpostavljena velikim količinam različnih podatkov, zaradi česar je razmejevanje med informacijami in dezinformacijami težko (Flogie idr. 2014). Tako je danes učinkovito sprejemanje, vrednotenje in predelovanje informacij v uporabno znanje ključna veščina. Mladi morajo ta znanja, vrednote in veščine pridobiti že v izobraževalnem procesu. Le tako se bodo lahko aktivno vključili na trg dela, se vseživljenjsko izobraževali in bili vključeni v sodobno družbo. Znanja, spretnosti in veščine za uporabo I KT imenujemo digitalna pismenost.

Gilster (1997) slednjo opredeli kot zmožnost razumevanja in uporabe informacij, dosegljivih $\mathrm{v}$ različnih formatih iz različnih digitalnih virov. Digitalna pismenost tako vključuje zmožnost rabe digitalne tehnologije, komunikacijskih orodij in omrežij s ciljem identifikacije, vrednotenja, uporabe in ustvarjanja novih informacij. Digitalno pismen uporabnik izkazuje interes in zmožnost iskanja in uporabe informacij, izgradnje novega znanja in komuniciranja $z$ drugimi uporabniki. Digitalno pismen posameznik je lahko aktiven član družbe (Junge in Hadjivassiliou 2015). Med raziskovalci obstaja strinjanje, da različne pismenosti, povezane z IKT, stremijo k skupnemu konceptu digitalne pismenosti (Tornero 2004). V desetletju po prvi omembi tega pojma je bilo predstavljenih več različnih opredelitev. Večina avtorjev je digitalno pismenost predstavila kot rezultat kompleksnih povezav posameznikovih sposobnosti, veščin in znanja. Tornero (2004) jo opredeli kot skupek naslednjih zmožnosti: tehničnih veščin, intelektualnih kompetence in kompetenc odgovornega državljana. Te zmožnosti omogočajo razvoj posameznika v informacijski družbi. Pietrass (2007) poudarja kritično razumevanje 
medijev in njihov socialni, ekonomski in družbeno-kulturni vpliv. V novem tisočletju tako poudarek koncepta digitalne pismenosti ni več na tehničnem vidiku, temveč bolj na refleksivnem. Okvir E T S (2002), na podlagi katerega je bilo razvito tudi ocenjevanje I K T-pismenosti P IS A, ${ }^{1}$ digitalno pismenost označuje kot zmožnost uporabe komunikacijskih tehnologij in orodij za dostopanje, upravljanje, povezovanje, vrednotenje in ustvarjanje informacij.

Z digitalno pismenostjo se je ukvarjal projekt PRIN, ki ga je pripravila skupina raziskovalcev italijanskih univerz. ${ }^{2} \mathrm{~V}$ njegovem okviru so razvili model za ocenjevanje digitalne pismenosti »Digital Competence Assessment « oziroma model D C A. Pri razvoju modela so izhajali iz kompleksnih konceptov različnih avtorjev, katerih ključno vodilo je bila ugotovitev, da je digitalna pismenost skupek različnih z I K T povezanih pismenosti in ostalih življenjskih veščin (Calvani idr. 2009).

V javnosti se za označevanje digitalne pismenosti uporabljajo številni izrazi, ki pa se med seboj razlikujejo. Tako tehnološko pismen posameznik (I K T-pismenost) pozna tehnologijo in osnovne veščine uporabe računalnika. Informacijska pismenost vključuje predvsem zmožnost iskanja, dostopanja, vrednotenja in uporabe na spletu dostopnih informacij. Vizualna pismenost je ključnega pomena za učenje in komuniciranje v sodobni družbi, odraža pa sposobnost razumevanja vizualnih sporočil in simbolov. $Z$ razvojem in popularizacijo spleta zajemajo spletne strani poleg besedil tudi slike, avdio, video in ostale digitalne oziroma medijske vsebine, s katerimi povezujemo medijsko pismenost. Ta tako odraža zmožnost dostopanja, analize, vrednotenja in ustvarjanja sporočil v različnih formatih, hkrati pa gradi razumevanje vloge medijev v družbi in samoizražanja, ki so osnova za državljansko demokracijo. ${ }^{3}$

Na podlagi teh izhodišč so avtorji raziskave digitalno pismenost opredelili kot sposobnost prilagodljivega raziskovanja novih tehnoloških potencialov, izbire, analize in kritičnega vrednotenja podatkov ter informacij z namenom reševanja problemov, sodelovanja, izgradnje novih znanj in hkrati spodbujanja zavesti o osebni odgovornosti ter spoštovanju pravic (Calvani idr. 2012).

Okvir ocenjevanja digitalne pismenosti (D CA) tako poudarja vključevanje in sobivanje naslednjih dimenzij:

\footnotetext{
${ }^{1}$ Programe for International Student Assessment, glej https://www.oecd.org/pisa/.

${ }^{2}$ Univerze iz Firenc, Torina, Casina in Salerna.

${ }^{3}$ Glej http://www.medialit.org.
} 
- tehnološke dimenzije, ki vključuje sposobnost razumevanja, raziskovanja in vključevanja sodobnih tehnologij pri reševanju problemov,

- kognitivne oziroma miselne dimenzije, ki vključuje sposobnost zbiranja, razlaganja in vrednotenja zbranih podatkov ob upoštevanju njihove ustreznosti in zanesljivosti,

- etične dimenzije, v katero je vključena sposobnost konstruktivnega sodelovanja in občutka odgovornosti do sebe in drugih posameznikov,

- povezovalne dimenzije, v katero je vključena sposobnost razumevanja potenciala, ki ga nudijo nove tehnologije pri sodelovanju in izgradnji novih znanj.

Marca 2010 je Evropska komisija z namenom soočanja z izzivi naslednjih desetletij pripravila strategijo Evropa 2020, katere pomemben del je tudi Digitalna agenda. ${ }^{4}$ Njeni ukrepi temeljijo na sedmih stebrih, med katerimi je tudi izboljšanje digitalne pismenosti, znanj in vključenosti. Poleg tega sta Evropski parlament in Svet Evrope ${ }^{5}$ leta 2006 objavila priporočilo o ključnih kompetencah za vseživljenjsko učenje (Uradni list Evropske unije 2006/L394). V njem vsem državam članicam $\mathrm{E}^{6}$ priporoča pripravo smernic za vključevanje veščin digitalne pismenosti v vse oblike formalnega izobraževanja. Digitalno pismenost (kot eno od osmih ključnih kompetenc vseživljenjskega učenja) opredelijo kot sposobnost razumevanja in poznavanja narave, vloge in priložnosti, ki jo nudi uporaba I K T v zasebnem in socialnem življenju ter pri delu. To vključuje poznavanje glavnih računalniških aplikacij, kot so urejevalniki besedil, preglednic, zbirk podatkov, shranjevanja in upravljanja podatkov, razumevanje možnosti in potencialnih nevarnosti interneta ter sporazumevanje s pomočjo elektronskih medijev. Posameznik mora tudi razumeti, kako IK T podpira ustvarjalnost in inovativnost, hkrati pa se zavedati vprašanj glede varnosti, veljavnosti, zanesljivosti ter pravnih in etičnih načel pri uporabi pridobljenih informacij. ${ }^{7}$

\footnotetext{
${ }^{4}$ Strategija razvoja informacijske družbe do leta 2020, glej http://www.mizs.gov.si/ fileadmin/mizs.gov.si/pageuploads/Informacijska_druzba/pdf/DSi_Strategija_ID _2020_20150306.pdf.

${ }^{5}$ Svet Evrope je mednarodna organizacija, ki jo sestavlja 47 držav iz evropske regije, ustanovljena je bila 5. maja 1949 z Londonskim sporazumom.

${ }^{6}$ Glej http://europa.eu/about-eu/countries/member-countries/.

${ }^{7}$ Glej http://ec.europa.eu/education/policy/school/competences_sl.htm.
} 
Tehnološki razvoj, predvsem pa povečanje dostopnosti do interneta, je spremenil način življenja in delovanja otrok tako $\mathrm{v}$ šoli kot doma. Če je bil še leta 2005 spletni promet zasebnih uporabnikov primerljiv s spletnim prometom poslovnih uporabnikov, se je leta 2011 to razmerje spremenilo v 4:1 v korist zasebnih uporabnikov. Posebno velik skok je na področju mobilnega dostopa do spleta, ki je od leta 2006 do leta 2011 narasel kar za 150-krat (O E C D 2013). Raziskava Statističnega urada Republike Slovenije (2015b) je pokazala, da ima dostop do interneta $78 \%$ vseh gospodinjstev, uporablja pa ga $73 \%$ oseb, starih od 16 do 74 let. V primerjavi z letom 2013 se je povečal delež uporabnikov s prenosnimi napravami (prenosniki - $60 \%$ leta $2015 \mathrm{v}$ primerjavi s $56 \%$ leta 2013; tablični računalniki - $24 \% \mathrm{v}$ primerjavi s $16 \%$ leta 2013). Močno se je povečal delež uporabnikov mobilnega dostopa do interneta (vsaj 3G), in sicer na $52 \%$ v primerjavi s $34 \%$ leta 2013. Evropski statistični urad (v nadaljevanju Eurostat) v raziskavi o rabi interneta in I K $\mathrm{T}$ zbira podatke o spretnostih in veščinah posameznikov. $V$ okviru indikatorjev digitalne agende Evrope $^{8}$ za leto 2015 je le 12,3\% posameznikov v Sloveniji kadar koli napisalo računalniški program ${ }^{9}$ in le $10,3 \%$ jih je ustvarilo svojo spletno stran. Raziskava na strani trga dela pokaže, da $47,6 \%$ vseh zaposlenih pri svojem delu uporablja računalnik, hkrati pa jih 17,8\% meni, da njihovo znanje s področja I K T ne zadošča zahtevam delodajalca.

V srednješolske programe gimnazije (splošne in strokovne) se v povprečju vpiše med 35 in $40 \%$ populacije, ki zaključi devetletno obvezno šolanje (Statistični urad Republike Slovenije 2015a). Gimnazijski programi se delijo na splošni program in programe strokovnih tehniških, ekonomskih in umetniških smeri. Med cilji prenove programov, ki je potekala v letih 2008-2014, je bilo med razvojnimi prioritetami tudi spodbujanje razvoja digitalne pismenosti skozi uporabo I K T pri vseh predmetih. Strategija prenove je vključevala uvedbo prilagodljivega predmetnika v povezavi $\mathrm{z}$ raznolikimi učnimi metodami, ki spodbujajo sodelovanje dijakov, ustvarjalnost in zadovoljstvo, kritično razmišljanje in reševanje problemov. Smiselna raba IKT je vključena v vseh ciljih prenove oziroma v celoten kurikul, kar omogoča preoblikovanje učenja in ustvarjanje bogatega interaktivnega okolja (U N E S CO 2005).

$\mathrm{Na}$ osnovi spremenjenih učnih programov, izobraževanja učiteljev

\footnotetext{
${ }^{8}$ Digital Agenda for Europe Scoreboard.

${ }^{9}$ Posamezniki, ki so za pisanje računalniškega programa uporabljali specializirani programski jezik.
} 
za rabo I K T prek projektov Računalniškega opismenjevanja (RO 19942003) in E-šolstva (2008-2013) ter opravljenih raziskav (Brečko, Vehovar in Dolničar 2008) ugotavljamo, da so v slovenskih šolah izpolnjeni zadostni pogoji za sodobno, z I K T podprto poučevanje in s tem za razvoj veščin digitalne pismenosti. Raziskava Eurostata ${ }^{10}$ je pokazala, da v Sloveniji kar 83\% (povprečje E U-28 je 74\%) mladostnikov med 16. in 19. letom kot glavni vir pridobivanja digitalnih spretnosti navaja formalno izobraževanje v šoli.

Opravljena raziskava računalniške in internetne pismenosti slovenske mladine (Sulčič 2011) kaže, da bi le 53,7\% dijakov in 63,6 \% študentov pridobilo računalniško spričevalo ECDL ${ }^{11}$ Primerljiva raziskava med italijanskimi mladostniki (Calvani idr. 2012) pa je pokazala, da je pričakovano raven 75 odstotne uspešnosti dosegla le četrtina srednješolcev. Sklepamo, da je tudi pri slovenski srednješolski populaciji napredek premajhen in za razvoj informacijske družbe neustrezen. Glede na vsa prizadevanja za dvig digitalne pismenosti $v$ nacionalnem in evropskem prostoru, smo z raziskavo želeli preveriti, kaj se dogaja $\mathrm{z}$ digitalno pismenostjo $35-40 \%$ srednješolske populacije, ${ }^{12}$ ki se vpiše v gimnazijske izobraževalne programe.

V okviru teoretičnega ozadja naše empirične raziskave najprej predstavljamo osnovno terminologijo ter metodološke okvire za merjenje digitalne pismenosti. Sledi predstavitev srednješolskega izobraževanja v Sloveniji, s poudarkom na gimnazijskem izobraževanju, ki je predmet empirične raziskave, predstavljene $\mathrm{v}$ drugem delu monografije. Izbor področja raziskovanja temelji na dejstvu, da so bili gimnazijski programi leta 2008 prenovljeni, prenova pa je vključevala spodbujanje digitalne pismenosti dijakov. Zanimalo nas je, kako prenovljeni kurikul vpliva na razvoj digitalnih kompetenc dijakov gimnazijskih programov. Zato smo v raziskavo vključili le dijake 1 . in 4. letnikov splošnih in strokovnih gimnazijskih programov. Seveda smo predpostavljali, da se izobraževalni proces gimnazijskih programov izvaja skladno s prenovljenim kurikulom in da imajo šole za to izpolnjene potrebne materialne pogoje. Raziskavo smo izvedli s predpostavko, da se bodo povabljene šole odzvale na vabilo in bodo njihova vodstva pripravljena sodelovati pri anketira-

\footnotetext{
${ }^{10}$ Glej http://ec.europa.eu/eurostat.

${ }^{11}$ Glej http://www.ecdl.si.

${ }^{12}$ Po podatkih Statističnega urada Republike Slovenije (2015a) se v gimnazijske programe vključuje 25 do $40 \%$ generacije, ki zaključuje osnovnošolsko izobraževanje.
} 
nju. Predpostavljali smo tudi, da bomo $\mathrm{z}$ anketo zbrali zadostno število odgovorov in da bodo dijaki anketo izpolnili vestno in natančno.

Raziskavo na gimnazijskih programih smo opravili s pomočjo okvira D CA, ki vključuje tehnološko, kognitivno, etično in povezovalno dimenzijo. Z raziskavo smo želeli preveriti naslednje hipoteze:

H1 Obstaja statistično značilna povezanost med intenzivnostjo uporabe IKT pri pouku in stopnjo digitalne pismenosti dijakov gimnazijskih programov.

H 2 Dijaki strokovnih gimnazij dosegajo pri posameznih dimenzijah digitalne pismenosti v povprečju boljši rezultat kot dijaki splošnih gimnazij.

H3 Obstajajo statistično značilne razlike v posameznih dimenzijah digitalne pismenosti glede na spol.

$\mathrm{H} 4$ Obstajajo statistično značilne razlike v posameznih dimenzijah digitalne pismenosti glede na regijo, $v$ kateri se izvaja gimnazijski program.

Rezultate raziskave in postopek preverjanja hipotez prikazujemo $\mathrm{v}$ poglavju 6. 


\section{Informacijsko-komunikacijska tehnologija in digitalna pismenost}

\subsection{Opredelitev osnovnih pojmov}

Razvoj I K T je v naše vsakdanje življenje prinesel mnoge spremembe in izzive, velik vpliv pa ima tudi na izobraževalnem področju, kjer učitelji v svoje delo lahko vključujejo raznolika izobraževalna digitalna gradiva, odprta učna okolja in platforme. Znanja s področja IKT in zmožnost vseživljenjskega učenja je potrebno usvajati že v procesu izobraževanja. Za zmožnost uporabe I K T so se razvili različni izrazi, ki se med seboj bolj ali manj razlikujejo. Poglejmo nekatere od njih.

Pojem digitalna pismenost je večplasten in pokriva različna področja pismenosti ter se razvija skladno s tehnologijo. Predstavlja univerzalno in bazično potrebo vseh državljanov pri delu, življenju in učenju v družbi znanja. Digitalno pismen posameznik lahko prispeva h koristi države na različnih področjih, kot so socialno, zdravstveno, ekonomsko, civilno, kulturno in družbeno (Ala-Mutka 2011), hkrati pa je osebno sposoben razumeti pomen medijev, iskanja informaciji, kritičnega vrednotenja in komuniciranja prek uporabe različnih orodij, storitev ali aplikacij.

Evropska unija prek razvojnih pobud in ukrepov, spodbuja uporabo I K T pri učenju in poučevanju. Le-ta je postala tudi prednostna naloga izobraževalnih politik razvitih držav in znanstvenih raziskav. Kot rezultat teh ukrepov velja omeniti pobude Digitalna agenda Evrope, ${ }^{1}$ Rethinking Education, ${ }^{2}$ OpeningUp ${ }^{3}$ in Grand Coalition for Digital Jobs. ${ }^{4}$

Danes ni več dvoma, da živimo v digitalni družbi, ki zahteva nova znanja in sposobnosti. Digitalna pismenost je ena izmed temeljnih življenjskih veščin (Bowden 2001), nekateri avtorji (Eshet-Alkalai 2004)

${ }^{1}$ Glej https://ec.europa.eu/digital-agenda/en.

${ }^{2}$ Glej http://ec.europa.eu/languages/policy/strategic-framework/rethinking-education _sl.htm.

${ }^{3}$ Glej http://www.openeducationeuropa.eu/sl/initiative.

${ }^{4}$ Glej https://ec.europa.eu/digital-agenda/en/grand-coalition-digital-jobs. 
jo imenujejo celo veščina »preživetja«. Hkrati je tudi transverzalna veščina, ker omogoča usvajanje ostalih ključnih kompetenc, kot so znanje jezikov, matematična kompetenca ali učenje učenja. Povezana je z mnogimi t.i. veščinami 21. stoletja, ki naj bi jih imeli posamezniki za zagotavljanje lastnega sodelovanja v sodobni družbi in ekonomiji.

Koncept digitalne pismenosti je kot izraz, ki je danes sprejet in uporabljan, prvič predstavil Gilster v svoji knjigi z enakim naslovom (Gilster 1997). Digitalno pismenost opredeli kot zmožnost pridobivanja in uporabe informacij, pridobljenih iz različnih digitalnih virov, oziroma kot pismenost $\mathrm{v}$ digitalni dobi (prav tam). Značilnost te opredelitve je, da avtor ni podal jasnega in natančnega seznama veščin, ki naj bi jih potreboval digitalno pismen posameznik, temveč je bila njegova glavna ideja povezati pojmovanje pismenosti kot zmožnosti branja, pisanja in obdelave informacij z uporabo tehnologije, dostopne v trenutnem časovnem okviru. Raziskovalci, ki so se kasneje sklicevali na Gilsterja, so kljub vsemu iz besedila izluščili osnovni nabor veščin, povezanih z generalno idejo digitalne pismenosti (Bowden 2001):

- izgradnjo novih sklopov znanja prek povezovanja informacij, pridobljenih iz različnih virov,

- kritično presojo pridobljenih informacij s poudarkom na veljavnosti in popolnosti internetnih virov,

- zavedanje o pomembnosti tradicionalnih orodij v povezavi z novimi mediji,

- zavedanje o »omrežju ljudi« kot viru za nasvete in pomoč,

- uporabo filtrov za organiziranje pridobivanja informacij in

- zmožnost objavljanja in dostopanja do informacij ter komuniciranja.

Zavedanje o pomenu novih znanj se je sicer pojavilo že konec 6o. let prejšnjega stoletja, ko je postalo jasno, da bodo računalniki kmalu dostopni širši populaciji. Po Bowdnu (2001) lahko koncept računalniške pismenosti razdelimo $\mathrm{v}$ tri faze:

1. Za mojstrsko fazo (do sredine 8o. let) je bilo značilno dojemanje računalnikov kot skrivnostnih in zmogljivih naprav, zato je bilo najprej potrebno usvojiti zelo specializirana znanja o samem delovanju računalnikov in programiranju $\mathrm{v}$ takrat dostopnih programskih jezikih. 
2. Aplikativna faza (od sredine 8o. let do sredine 9o. let) sovpada $s$ pojavom in razvojem grafičnih vmesnikov in programov, ki so omogočili uporabo računalnikov širšim množicam. V tej fazi je bila uporaba računalnika prvič videna kot orodje za izobraževalne namene, najpomembnejša veščina pa je postala poznavanje uporabe programske opreme, kar je pomenilo, da se je zahtevano znanje premaknilo iz računalniške strojne na računalniško programsko opremo. V tem času je največkrat omenjena t.i. računalniška ali IKT-pismenost, ki temelji na veščini uporabe programov in ne več na specializiranih znanjih o delovanju računalnikov.

3. Refleksivna faza (pozna 9o. leta do danes) predstavlja dokončno spoznanje o neomejenih možnostih novih tehnologij. Glavni povod za tako razmišljanje je bil množičen prehod na svetovni splet oziroma njegova množična uporaba. Osrednje pojmovanje digitalnih veščin $\mathrm{v}$ tem času je bilo največkrat označeno $\mathrm{z}$ informacijsko pismenostjo, kajti ravno lažja in enostavna dostopnost do informacij je predstavljala zahtevo po dodatnih znanjih s področja kognicije, kritične presoje ter etične in varne rabe spleta. Informacijsko pismenost so opredelili kot nabor veščin in znanj, ki so omogočala (E T S 2002):

- dostopanje - kako in kje zbiramo in dostopamo do informacij,

- upravljanje - uporaba organizacijskih oziroma klasifikacijskih shem,

- integracijo - tolmačenje, primerjava, povzemanje in predstavitev informacij,

- vrednotenje - ocena o kakovosti, relevantnosti, uporabnosti ali učinkovitosti informacij ter

- ustvarjanje - prilagajanje, uporaba, zbiranje in kreiranje novih znanj iz obstoječih naborov informacij.

Pomembno spoznanje pri preučevanju digitalne pismenosti je tisto o njeni raznolikosti, saj zajema tako tehnološka znanja kot socialne, etične in refleksivne vidike, ki so del učenja, dela in vsakdanjega življenja posameznika. Pogosto se je uporabljal tudi izraz "multipismenost«, ki je opisoval različne spretnosti, potrebne za uporabo, razumevanje in ustvarjanje digitalnih vsebin. Digitalna pismenost tako ne predstavlja konkretnega nabora veščin, temveč jo lahko razumemo kot okvir med seboj povezanih pismenosti, med katere spadajo medijska, tehnološka, informacijska, vizualna, komunikacijska in socialna pismenost. 
Medijska pismenost odraža sposobnost dostopanja, analize, vrednotenja in ustvarjanja različnih oblik digitalnih vsebin. Izhaja iz potrebe po upravljanju sodobnih vsebin, ki poleg besedila vsebujejo še raznolike oblike avdio-, video- in drugih medijskih vsebin. Posameznik mora razumeti pomen in sporočilo $\mathrm{v}$ različnih oblikah, oceniti vpliv medijev, razumeti sestavo besedil in možnost vpliva medijev pri komuniciranju. Pri izobraževanju je medijska pismenost vključena tako v proces učenja kot v razumevanje koncepta obogatenih besedil (Hobbs 2011).

Tehnološka pismenost pokriva veščine, ki jih posameznik potrebuje za zahtevnejša računalniška opravila, kot so urejanje video- ali avdiovsebin in pisanje programske kode. Te veščine so seveda pomembne, a vedeti je treba, da še tako visoka stopnja tehnološke pismenosti ne zagotavlja kritične in varne rabe na spletu pridobljenih informacij. Učenec lahko $\mathrm{v}$ šoli še vedno kopira besedila neposredno s spleta, ne spoštuje avtorskih pravic ali zasebnosti v svojih spletnih aktivnostih.

Informacijska pismenost se je omenjala in razvijala predvsem $\mathrm{v}$ knjižničarstvu, in to že pred pojavom digitalnih vsebin. $Z$ množičnim dostopom do spleta in s tem do skoraj neomejenih količin informacij pa je pridobila na pomembnosti tudi izven bibliotekarskega področja. Ameriško združenje fakultetnih in raziskovalnih knjižnic (ACLR 2000) je v zvezi z informacijsko pismenostjo predstavilo nabor potrebnih veščin, ki jih mora imeti informacijsko pismen posameznik. Informacijsko pismen posameznik tako:

- zna določiti obseg in naravo potrebnih informacij,

- učinkovito dostopa do želenih informacij,

- pridobljene informacije kritično vrednoti po virih dosegljivosti in vključuje izbrane informacije v nabore svojega znanja,

- učinkovito uporablja informacije za dosego določenega namena,

- razume ekonomske, pravne in socialne vidike uporabe pridobivanja informacij, pridobljene informacije uporablja v skladu $\mathrm{z}$ etičnimi standardi.

Z razvojem zmožnosti prenosa in prikaza digitalnih vsebin se je povečevala tudi uporaba slik oziroma simbolov, ki nadomeščajo besedilo. Veščino razumevanja in kreiranja vizualnih sporočil skozi uporabo simbolov povezujemo z vizualno pismenostjo. Pojem je prvič predstavil Debes leta 1968 in ga označil kot veščino, potrebno za učenje in komuniciranje v moderni družbi (Braden 2001). 
Komunikacijska pismenost predstavlja veščine, ki so osnova za preudarno in organizirano povezovanje $\mathrm{z}$ drugimi uporabniki $\mathrm{v}$ skupnih omrežjih. Predvsem hiter razvoj mobilne tehnologije v zadnjih letih je prinesel nove, hitrejše in zmogljivejše komunikacijske kanale, obenem pa potrebo ne samo po razumevanju povezovanja znanja iz različnih virov, temveč tudi po uporabi teh virov za širjenje in povezovanje znanj (Jenkins 2009). Skladno s povezovanjem in komuniciranjem preko družabnih omrežij se razvija t.i. "participativna kultura«, kjer prek veščin socialne pismenosti posamezniki razumejo zmožnosti kolektivnega sodelovanja, kulturnih in družbenih razlik ter usklajevanja informacij, ki tvorijo sliko sveta okoli njih.

Kot vidimo, so digitalne veščine raznovrstne. Mednarodno združenje za tehnologijo v izobraževanju (IS T E) ${ }^{5}$ je merila za določanje veščin digitalne pismenosti razvrstilo v naslednje sklope veščin:

- ustvarjalnost in inovativnost,

- komunikacija in sodelovanje,

- raziskovanje in informacijska pretočnost,

- kritično mišljenje,

- reševanje problemov in odločanje,

- tehnološke operacije in koncepti.

Koncept digitalne pismenosti je potemtakem večplasten, zajema različna področja in pismenosti ter se razvija skladno $\mathrm{z}$ razvojem tehnologije. Digitalno pismen posameznik razume pomen in vlogo sodobnih medijev (ki so v večini digitalizirani), suvereno in s kritično distanco išče informacije ter je sposoben komunicirati z drugimi s pomočjo uporabe digitalnih orodij in aplikacij.

Večina raziskovalnih okvirov, ki poskušajo opredeliti digitalno pismenost, se osredotoča na razvoj veščin in uporabe specializiranih orodij. Skupek teh opredelitev, kot jih povzema Ferrari (2012), digitalno pismenost definira kot nabor znanj, veščin in navad (zmožnosti, strategije, vrednote in zavedanja), ki jih ob uporabi I K T potrebujemo za izvajanje nalog, reševanje problemov, komuniciranje, upravljanje informacij, sodelovanje, ustvarjanje in izmenjavo vsebin ter uspešno, učinkovito in kritično izgradnjo lastnega znanja.

Po National Council for Curriculum and Assessment (2004) obstajajo vsaj trije razlogi za spodbujanje vključevanja I K T na področje izobraže-

${ }^{5}$ Glej http://www.iste.org/. 
vanja. Prvi se nanaša na potenciale, ki jih uporaba I K T prinaša na področju poučevanja in učenja, predvsem $\mathrm{v}$ smeri sodobnih učnih metod in motivacije učečih. Drugi razlog digitalno pismenost vidi kot nujno potrebno za delovanje posameznika v družbi znanja (Eshet-Alkalai 2004), tretji pa svari pred digitalnim razkorakom, med posamezniki, ki imajo, in tistimi, ki nimajo dostopa do aktivnega sodelovanja v digitalni družbi.

\subsection{Pobude in projekti za spodbujanje razvoja digitalne pismenosti}

Metodološki pristop k merjenju digitalne pismenosti je zaradi kompleksnosti veščin in opredelitev v prvem koraku vključeval povezovanje teoretičnega razumevanja digitalne pismenosti s sorodnimi pismenostmi (Ala-Mutka 2011). Naslednji korak je bila selekcija in razvrščanje zbranih okvirov, ki so bili razumljeni v širšem kontekstu kot organizirana klasifikacija kompetenc in podkompetenc. Kot navaja CE DE F OP (2008), je kvalificirani okvir instrument za razvoj in oceno digitalne pismenosti glede na niz meril ter ciljno skupino.

V poročilu o projektu DI G C O M P je A. Ferrari (2012) preučila 15 okvirov za opredelitev digitalne pismenosti. Namen njenega poročila je bil ugotoviti in analizirati že izvedene projekte in pobude, pri katerih so spodbujali, razvijali, učili, ocenjevali ali izdajali potrdila o digitalni pismenosti. Skozi raziskavo je preučila nabor kompetenc in podkompetenc, ki so jih pri posameznih projektih ali pobudah vključili v razumevanje digitalne pismenosti. Glavni cilji njenega preučevanja so bili:

- identificirati ključne sestavine digitalne pismenosti v smislu znanj, veščin in stališč,

- razviti opisnike, ki bodo vključeni v konceptualni okvir,

- predlagati načrt uporabe in načine prilagajanja okvira ter opisnikov različnim ravnem.

V nadaljevanju po abecednem vrstnem redu navajamo kratek opis, cilje in ciljne skupine izvedenih merjenj digitalne pismenosti (preglednica 2.1).

Katalonska vlada je leta 2009 prek projekta ACTIC (2013) pričela s promocijo digitalne pismenosti med državljani. Z njo so želeli prispevati k dinamični in konkurenčnejši družbi znanja, vzpodbuditi rabo I K T in izboljšati izobraževanje odraslih na njenem področju. Pomemben del 
Pobude in projekti za spodbujanje razvoja digitalne pismenosti $\mid 2.2$

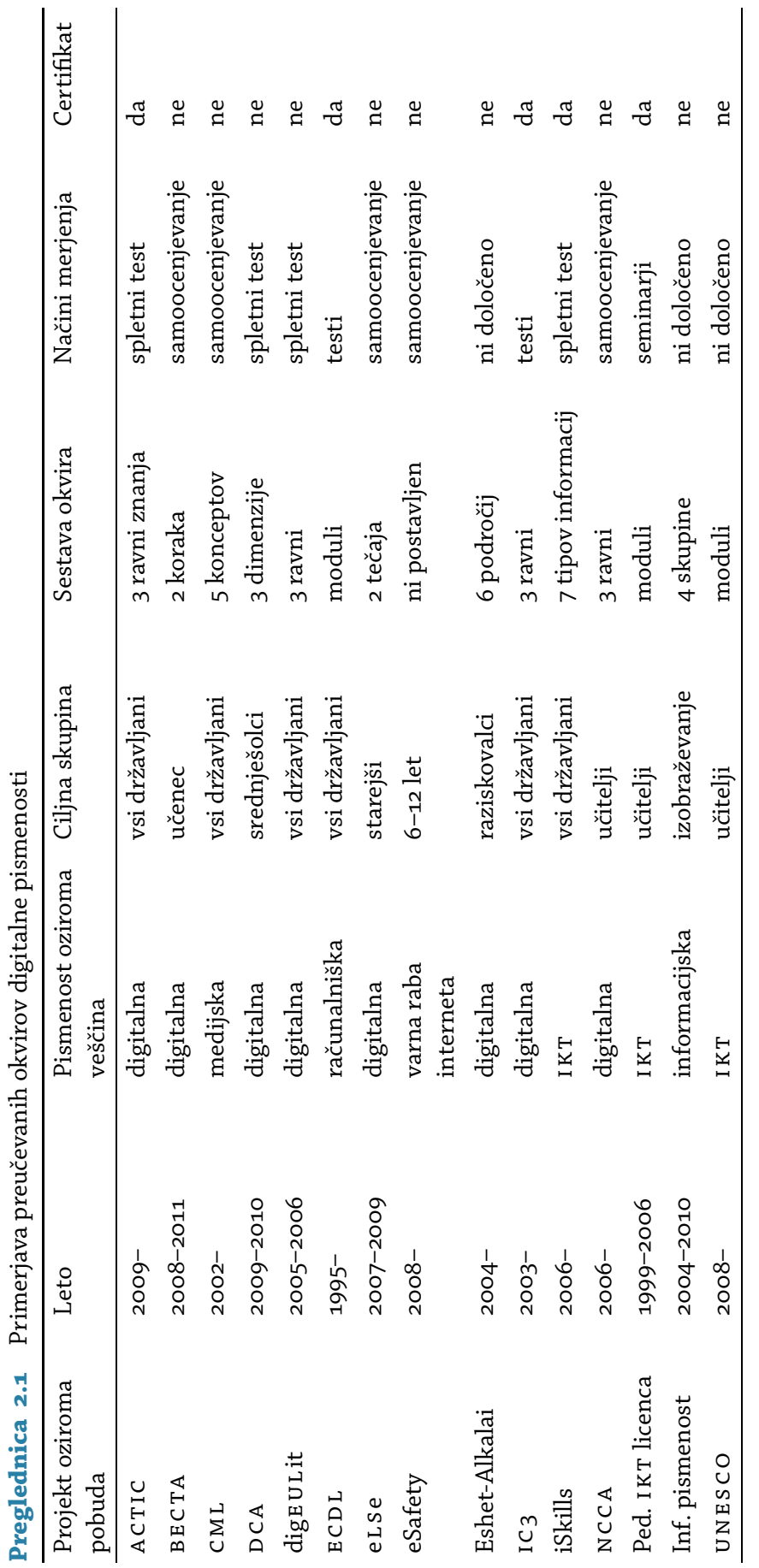


Raven 3: Napredno Iskanje priložnosti rabe I K T, podpora uporabnikom

Raven 2: Vmesno Avtonomna raba

Raven 1: Osnovno

Digitalna vključenost

Slika 2.1 Ravni znanja po modelu digitalne pismenosti ACT IC

projekta je bil tudi razvoj certificiranja doseženega znanja za potrebe zaposlovanja $v$ gospodarstvu.

Akreditacijski okvir projekta AC TIC je bil zgrajen na 8. skupinah veščin:

- digitalna participacija in kultura,

- digitalna tehnologija, uporaba računalnika in operacijskih sistemov,

- brskanje in komunikacija v digitalnem svetu,

- razumevanje pisnih informacij,

- razumevanje nenapisanih informacij (avdio, video, grafika),

- razumevanje numeričnih informacij,

- razumevanje zbirk podatkov in

- predstavitev vsebin.

Pri preverjanju stopnje digitalne pismenosti je bilo moč doseči tri ravni znanja (slika 2.1):

1. osnovni uporabnik $z$ osnovnim poznavanjem tehnologije,

2. avtonomni uporabnik, ki je vešč kritične ocene pridobljenih informacij,

3. napredni in inovativni uporabnik, zmožen izkoristiti potenciale I K T, poiskati alternative in podpirati druge uporabnike.

Certificiranje doseženega znanja so pooblaščeni centri izvajali z reševanjem spletnih testov, pri čemer so imeli posamezniki določen maksimalni čas reševanja testov.

Angleška izobraževalna agencija B Е C TA, ki jo je v letih med 1998 in 2011 financiralo Ministrstvo za izobraževanje Velike Britanije, je pripravila okvir digitalne pismenosti, namenjen spodbujanju izgradnje digitalne pismenosti za učitelje in učeče se $\mathrm{v}$ osnovnih ter srednjih šolah. Okvir je temeljil na razumevanju digitalne pismenosti kot kombinacije digitalnih veščin in veščin kritičnega mišljenja (Newman 2008). 
Slika 2.2

Veščine digitalne pismenosti po modelu BECTA

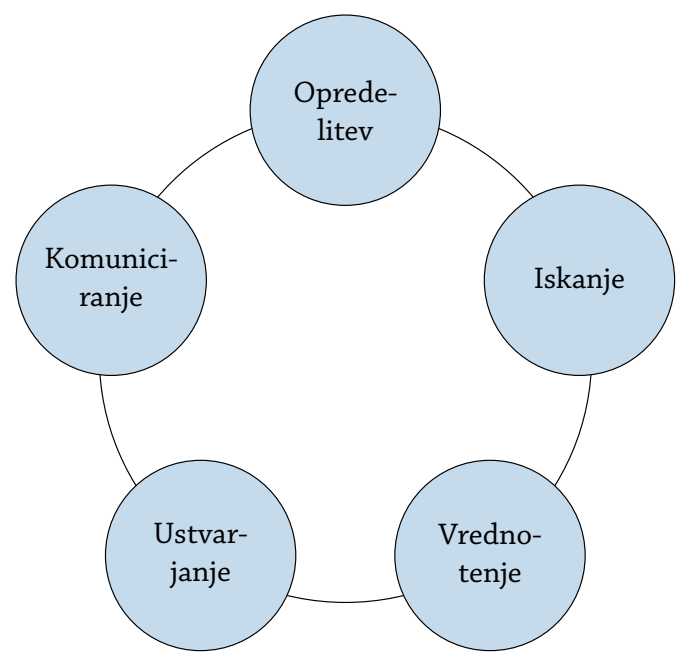

Pri njegovi izdelavi se je B E C T A osredotočila na opredelitev veščin digitalne pismenosti $\mathrm{v}$ navezi $\mathrm{z}$ informacijsko pismenostjo in varnostjo na spletu. ${ }^{6}$

Okvir digitalne pismenosti, kot so ga opredelili pri agenciji B Е C TA, digitalno pismenost razume kot skupek I K T veščin, kritičnega mišljenja, sodelovanja in socialnih nazorov. Sestavljen je iz naslednjih komponent (slika 2.2):

- opredelitve nalog in podajanja predlogov rešitev,

- iskanja informacij,

- vrednotenja pridobljenih informacij v smeri ciljne skupine in ciljev,

- ustvarjanja novih rešitev in predlogov ter

- komuniciranja in refleksije predlaganih rešitev.

Okvir ni opredelil možnosti doseganja ravni učenčeve digitalne pismenosti, temveč le dva razvojna koraka. Prvi korak (zaprta poizvedba) pomeni zmožnost odzivanja učenca na praktično zastavljeno vprašanje, medtem ko je pri drugem koraku (odprta poizvedba) učenec vešč postavljanja lastnih vprašanj v zvezi s podano problemsko situacijo.

Center za medijsko pismenost ( $\mathrm{CML}$ ) je izobraževalna organizacija, katere cilj je umestiti medijsko pismenost kot veščino 21. stoletja v smeri komuniciranja prek vseh dostopnih medijev z uporabo slik,

\footnotetext{
${ }^{6}$ Glej http://www.teachfind.com/becta/becta-schools-learning-and-teaching-digital -literacy-digital-literacy-guidance-schools.
} 
video-, avdiomaterialov in besed. Medijsko pismenost razumejo kot podlago in pogoj za dostopanje, analiziranje, vrednotenje, ustvarjanje in sodelovanje $\mathrm{v}$ sodobni digitalni družbi. Hkrati gradijo razumevanje vloge medijev v družbi in potrebne veščine samoizražanja, ki jih potrebuje posameznik v demokratični družbi. Okvir C M L opredeli 5 ključnih konceptov medijske pismenosti, in sicer: ${ }^{7}$

- vsa medijska sporočila so zgrajena iz več sestavin;

- medijska sporočila so ustvarjalno zgrajena s pomočjo vnaprejšnjih pravil;

- različni ljudje lahko sporočila dojemajo na različne načine;

- mediji poleg sporočilnosti vsebujejo tudi vrednote in stališča;

- večina sporočil je organiziranih tako, da prinašajo moč ali dobiček.

Okvir medijske pismenosti CML »MediaLit Kit« določa ključna znanja, ki izhajajo neposredno iz 5 ključnih konceptov raziskovanja medijskih sporočil. ${ }^{8}$ Medijsko pismen posameznik zna določiti avtorja medijskega sporočila, prepoznava različne formate slednjega ter njegovo ciljno skupino, določi njegov motiv in vsebino. Okvir ne predvideva ravni znanj, je pa za potrebe samoocene razvit vzorčni ocenjevalni model, ki je dostopen le naročnikom.

Znanja in veščine digitalne pismenosti je opredelil tudi okvir D CA, pri katerem je skupina raziskovalcev iz italijanskih univerz zasnovala model merjenja digitalne pismenosti in izmerila digitalno pismenost italijanskih srednješolcev (Calvani idr. 2012).

Njihov okvir je predvideval tri posamične dimenzije digitalne pismenosti in njihovo integracijo (Calvani, Fini in Ranieri 2010):

- tehnološko dimenzijo,, ki jo razumejo kot sposobnost prožnega raziskovanja in soočanja s problemskimi situacijami ob uporabi tehnologije,

- kognitivno dimenzijo, kjer so preverili sposobnost branja, izbire, razlage in vrednotenja podatkov ter informacij ob upoštevanju njihove ustreznosti in zanesljivosti,

- etično dimenzijo, ki vključuje sposobnost konstruktivne interakcije $\mathrm{z}$ ostalimi posamezniki in odgovorne rabe razpoložljive tehnologije,

${ }^{7}$ Glej http://www.medialit.org/about-cml.

${ }^{8}$ Glej http://www.medialit.org/cml-medialit-kit. 


\begin{tabular}{|l|}
\hline Transformacija \\
\hline Uporaba \\
\hline Kompetenca \\
\hline
\end{tabular}

Inovativnost

\section{Strokovna raba}

Slika 2.3 Ravni digitalne pismenosti po modelu DigEuLit

- integracijo vseh treh dimenzij, ki jo razumejo kot sposobnost razumevanja potencialov tehnologije pri izgradnji novih znanj.

Ciljna skupina preverjanja ravni digitalne pismenosti so bili mladostniki (15 let) vseh vrst italijanskih srednjih šol (poklicne, srednje strokovne in gimnazije). Preverjanje so izvajali s spletnim vprašalnikom v spletni učilnici Moodle. ${ }^{9}$ Teoretično zasnovo okvira in rezultate merjenja natančneje predstavljamo v poglavju 3.2.

Naslednji preučevani projekt je digE U Lit (Digital E U Literacy). ${ }^{10} \mathrm{~V}$ okviru projekta so želeli razviti evropski okvir digitalne pismenosti (Bélisle in Rosado 2006), ki naj bi omogočil opredelitev, strukturo in nabor orodij, s pomočjo katerih bi učitelji in učeči se razumeli ter delili znanje s področja spodbujanja digitalne pismenosti in ga vključevali v prakso.

Ob snovanju okvira digitalne pismenosti je delovna skupina Evropske komisije (Martin in Grudziecki 2006) določila nabor 13 procesov, ki jih posamezniki izvajajo ob svojem delu v digitalnem okolju. Navedeni procesi so del okvira digitalne pismenosti, ki je bil sestavljen iz treh ravni (Martin 2006) (slika 2.3):

1. digitalne kompetence, ki vključuje splošne veščine, povezane $z$ naborom opredeljenih procesov; znotraj prve ravni je moč napredovati na posameznih področjih in s tem od osnovnih do bolj analitičnih veščin;

2. digitalne uporabe, ki vključuje uporabo veščin digitalne kompetence v okviru naprednejših in strokovnejših kontekstov;

3. digitalne transformacije, kjer uporaba veščin digitalne kompetence poteka na inovativen in ustvarjalen način, kar vodi $\mathrm{k}$ spremembi na individualni ali organizacijski ravni.

Razvita je bila tudi metodologija, s pomočjo katere bi posameznik s spletnimi orodji lahko ustvaril svoj profil, določal svojo raven digitalne

${ }^{9}$ Glej http://www.moodle.org.

${ }^{10}$ Glej http://www.openeducationeuropa.eu/fr/node/2551. 
pismenosti, načrtoval potrebe po nadaljnjih znanjih in spremljal svoj napredek $\mathrm{z}$ učnim dnevnikom.

Najbolj poznan okvir merjenja digitalnih veščin v Sloveniji je mednarodna izobraževalna pobuda E CDL. Po posameznih državah jo upravlja neodvisno telo, v Sloveniji pa Slovensko društvo Informatika. ${ }^{11} \mathrm{Cilj}$ pobude ECDL je širjenje digitalne pismenosti po svetu, ponujanje kakovostnih certificiranih programov, razvoj posameznikov, organizacij in družbe. ${ }^{12}$

Okvir ECDL je sestavljen iz dveh predstavitvenih modulov (EqualSkills in e-Citizen), 13 modulov osnovnega programa E CDL, ki so med seboj neodvisni, in 4 modulov naprednega programa. Posamezni moduli pokrivajo naslednja področja: ${ }^{13}$

- Osnovni koncepti IKT, pri katerem posameznik pozna osnovno fizično zgradbo računalnika, razume njegov vpliv na zdravje ter varnostne in pravne vidike uporabe.

- Uporaba računalnika in upravljanje datotek, pri katerih se posameznik znajde v okolju z namiznim računalnikom, organizira kazala, datoteke in mape ter jih premika, kopira in briše.

- Urejevalnik besedil, kjer posameznik zna uporabljati programsko opremo za obdelavo besedil prek ustvarjanja, urejanja in zaključevanja dela v dokumentu do naprednejđih funkcij, kot sta ustvarjanje tabel in vključevanje slik.

- Preglednice, kjer posameznik zna uporabljati programsko opremo za preglednice prek opravil izračuna osnovnih matematičnih in logičnih operacij ter ustvarjanja grafikonov in diagramov.

- Baze podatkov, pri katerih posameznik razume osnovne koncepte podatkovnih baz, načrtuje preprosto podatkovno bazo in $\mathrm{v}$ njej opravlja poizvedbe.

- Predstavitve, kjer posameznik pripravi elektronsko predstavitev za ciljno skupino in zna uporabljati osnovne postopke uporabe grafičnih elementov ter diagramov.

- Brskanje po spletu in komuniciranje, pri katerem zna posameznik s pomočjo spletnega iskalnika na internetu poiskati želene infor-

\footnotetext{
${ }^{11}$ Glej http://www.drustvo-informatika.si/ecdl/.

${ }^{12}$ Glej http://www.ecdl.org/index.jsp?p=93\&n=100.

${ }^{13} \mathrm{Glej}$ http://www.ecdl.si/strani/program-1.htm.
} 
macije, jih natisniti v določenem obsegu ter uporabljati elektronsko pošto.

Naslednji moduli so povezani z 2D-oblikovanjem, urejanjem slik in spletnih strani, vzdrževanjem računalniškega sistema ter varnostjo in $\mathrm{s}$ projektnim načrtovanjem.

Program E CD L začne z uvodnimi veščinami za vse (angl. equal skills). Te veščine so povezane s predstavitvijo računalnika, e-pošte in spleta za popolne začetnike. $S$ t.i. "E-Citizen«-om postane posameznik edržavljan, kar pomeni, da zna uporabljati splet, komunicirati s posamezniki in skupinami, pridobivati informacije ter dostopati do e-storitev. Posamezni moduli pokrivajo tri ravni uporabe: osnovno, priporočeno in napredno.

Program ECDL/ICDL, kot glavni certificirani program, je sestavljen iz 13 modulov. Za dosego osnovne ravni digitalne pismenosti je potrebno opraviti vsaj 4 module, za priporočeno raven pa vsaj 7. Napredni $E C D L / I C D L$ pa je namenjen vsem, ki so uspešno opravili glavni program, omogoča pa bolj poglobljeno znanje s področja urejanja besedil, preglednic, predstavitev in baz podatkov. Posamezni moduli se lahko opravijo le pri pooblaščenem izpitnem centru. Za certificiranje je zadolžen nacionalni E CD L- skrbnik. ${ }^{14}$

Pomemben del pri razvoju informatizacije sodobnih družb je tudi preprečevanje digitalne izključenosti starejših. Tako je bil projekt e L Se, ki ga je vodil konzorcij partnerjev iz Nemčije, Španije, Velike Britanije, Švedske, Litve in Francije, namenjen starejšim državljanom iz držav partneric. Primarni cilj projekta else je bil povečanje socialne udeležbe, opolnomočenje in vključitev starejših v informacijsko družbo $s$ poudarkom na zmanjšanju izključenosti starejših posameznikov. Drugi cilj je bil razvoj učne platforme, ki je prilagojena uporabi s strani starejših brez ali z minimalno predhodnega znanja na področju rabe I K T. ${ }^{15}$

Starejšim osebam je bil prilagojen tudi okvir veščin digitalne pismenosti, ki je vključeval le osnovne in napredne veščine. Tako posameznik z osnovnimi veščinami zna:

- uporabljati učno platformo, kar pomeni, da se znajde $\mathrm{v}$ predvidenem učnem okolju, komunicira in pošilja datoteke, spoznava strukturo in vgrajene medijske elemente,

${ }^{14} \mathrm{Glej}$ http://www.drustvo-informatika.si/ecdl/.

${ }^{15} \mathrm{Glej}$ http://www.carenetproject.eu/the-else-academy-elearning-for-seniors-group/ ?lang=en. 
- pisati s pomočjo računalnika, kar vključuje osnovna opravila v urejevalniku besedil,

- ostati v stiku z ostalimi uporabniki na spletu, kar vključuje poznavanje rabe e-pošte in spletnih storitev za komuniciranje,

- poiskati želene informacije, kar pomeni, da napreduje na področju veščin pridobivanja informacij,

- vzdrževati računalnik, kar vključuje poznavanje načinov shranjevanja podatkov in vzdrževanja sistema,

- uporabljati spletne storitve, kar vključuje poznavanje in uporabo različnih storitev, ki so dosegljive prek spleta,

- poiskati nadaljnje možnosti e-izobraževanja, kar pomeni, da se zaveda možnosti vseživljenjskega učenja prek e-gradiv, dosegljivih prek spleta.

V skupino naprednih veščin vključujemo:

- komunikacijo prek spleta, kar vključuje poznavanje in uporabo naprednejših oblik komuniciranja, na primer uporaba programa Skype ali spletnih forumov;

- sposobnost enostavnega urejanja digitalnih fotografij s pomočjo namiznih ali spletnih orodij,

- izdelavo predstavitev, pri čemer posameznik upošteva osnovna načela dobrih predstavitev,

- sposobnost uporabljati spletne medije (uporaba radijskih in televizijskih kanalov na spletu.

Naslednja preučevana pobuda je eSafety Kit. Vodi ga Insafe, ${ }^{16}$ zveza mednarodnih organizacij, ki skrbi za ozaveščanje o varni in odgovorni rabi interneta ter mobilnih naprav. Pobudo sofinancira Evropska unija, njen partner iz Slovenije pa je Center za varnejši internet, ki ponuja storitve Safe.si, ${ }^{17}$ svetovalno linijo Tom in center za anonimne prijave nezakonitih spletnih vsebin Spletno oko. Cilj pobude eSafety Kit je povečanje zavedanja o potencialnih tveganjih, ki jih prinaša raba interneta, namenjena pa je otrokom $v$ starosti od 6. do 12. leta, njihovim staršem in učiteljem. Otroci naj bi spoznali oblike vizualne diskriminacije, kritičnega mišljenja, vrednot in zasebnosti. V skladu s cilji so izdelali in

${ }^{16}$ Glej https://www.betterinternetforkids.eu/.

${ }^{17}$ Glej http://www.safe.si/. 
predstavili knjižice in druge spletne aktivnosti, ki predstavljajo osnovo za razpravo o internetni varnosti med otrokom in starši ali učitelji.

Okvir veščin, ki naj bi jih v zvezi s problematiko varne rabe interneta spodbujali z razvojem izobraževalnih programov, pokriva naslednja področja:

- varnost na spletu, kar vključuje uporabo antivirusnih programov in filtrov, preprečevanje nezaželene e-pošte in S M S sporočil,

- komunikacijo, ki vključuje védenje o spletni identiteti in zasebnosti, netetiki, deljenju vsebin in mreženje,

- spletno nadlegovanje oziroma poznavanje problematike spletnega nadlegovanja ter varnostnih vidikov zaupanja,

- zabavo, kjer je vključeno védenje o prenosu in legalni uporabi programske opreme, avtorskih pravicah in zasebnosti.

V sklopu pobude je bila vzpostavljena tudi skupna spletna stran, kjer so predstavljene aktivnosti in povezave na nacionalne spletne strani z specifičnejšimi, nacionalno razvitimi publikacijami in vsebinami. Odprta je tudi spletna stran $\mathrm{z}$ aktivnostmi, ${ }^{18} \mathrm{ki}$ je $\mathrm{v}$ času pisanja pričujoče monografije dostopna $v 9$ jezikih. Za vsako področje oziroma tematiko so zbrane posamezne aktivnosti, ki so sestavljene iz nabora pravil, prenosov, kvizov in iger.

V okviru projekta so bili v 30 državah vzpostavljeni centri za varno rabo interneta. Informativna gradiva so prevedena $v 22$ jezikov.

Posamezniki morajo za opravljanje nalog in reševanje problemov $\mathrm{v}$ digitalnih okoljih uporabljati nabor tehničnih, kognitivnih in socioloških znanj. Po Eshet-Alkalaju (2004) predstavlja digitalna pismenost v digitalni dobi preživetveno veščino. Za potrebe nadaljnjega akademskega raziskovanja je predstavil okvir, ki poleg veščine uporabe digitalnih naprav in programske opreme vključuje še kompleksnejše miselne, motorične, sociološke in čustvene veščine (Eshet-Alkalai in AmichaiHamburger 2004).

Konceptualni okvir digitalne pismenosti (slika 2.4), kot ga opredeli Eshet-Alkalai, vsebuje šest področij pismenosti (Eshet-Alkalai in Chajut 2010):

- foto-vizualno pismenost, kar pomeni sposobnost branja grafičnih uporabniških vmesnikov, vizualno predstavljenih navodil in sporočil,

\footnotetext{
${ }^{18}$ Glej http://esafetykit.net/index2.html.
} 
Slika 2.4

Konceptualni okvir digitalne pismenosti Eshet-Alkalai

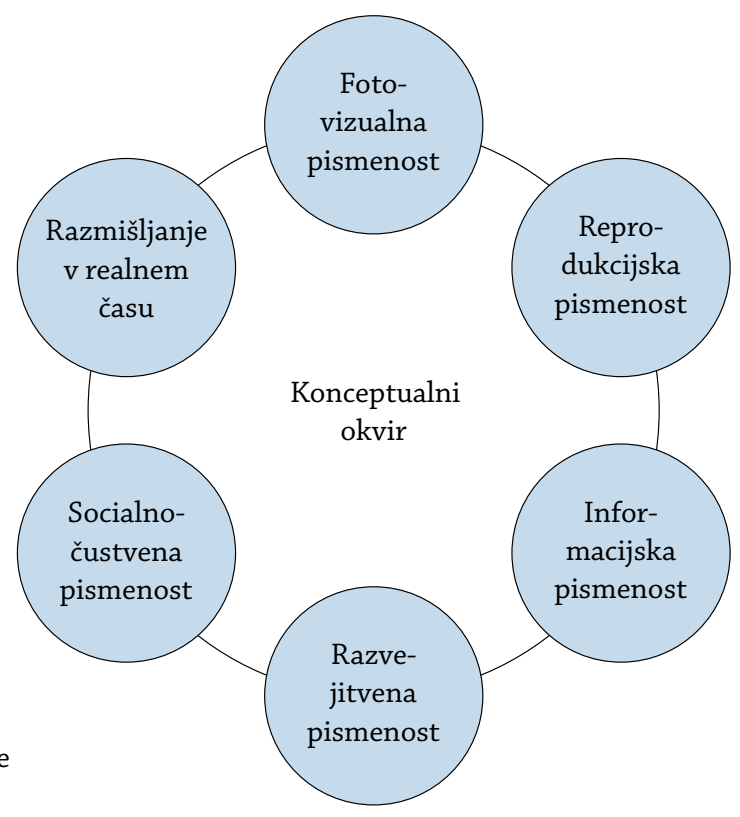

- reprodukcijsko pismenost, ki vključuje sposobnost ustvarjanja smiselnega, verodostojnega in ustvarjalnega sporočila,

- informacijsko pismenost oziroma kognitivno sposobnost učinkovitega vrednotenja pridobljenih informacij,

- razvejitveno pismenost oziroma sposobnost nelinearnega iskanja informacij in razvijanja večdimenzionalnega razmišljanja,

- socialno-čustveno pismenost, ki vključuje sposobnost izogibanja pastem in hkrati zavedanja o prednostih, ki jih prinaša digitalna komunikacija,

- razmišljanje v realnem času, ki je sposobnost obdelave in vrednotenja velikih količin podatkov $\mathrm{v}$ realnem času.

Okvir metodološko ni bil preverjan, temveč gre za zbirko strokovnih člankov, ki so bili objavljeni v obdobju med letoma 2004 in 2010.

Naslednji preučevani model, Global Standard 3, je mednarodno priznani standard digitalne pismenosti, ki odraža veščine in spretnosti, potrebne $\mathrm{v}$ današnjem akademskem in poslovnem okolju. ${ }^{19}$

\footnotetext{
${ }^{19}$ Glej http://www.certiport.com/portal/desktopdefault.aspx?page=common/ pagelibrary/icz-overview.html.
} 
Global Standard 3 je sestavljen iz treh posameznih izpitov: ${ }^{20}$

- osnov računalništva, ki vključujejo osnovno poznavanje strojne in programske opreme računalnika, operacijskih sistemov ter zmožnost odprave osnovnih napak,

- poznavanja ključne programske opreme, ki vključuje poznavanje programske opreme za urejanje besedil, izračune s pomočjo preglednic, in sestavljanje predstavitev,

- življenja na spletu oziroma poznavanja spletnih storitev, načinov komuniciranja, sodelovanja in učenja, družabnih omrežij ter etične in varne rabe interneta.

Certificiranje po programu IC3 temelji na ocenjevanju posameznih izpitov. Pozitivno rešeni izpiti vodijo $\mathrm{k}$ dodelitvi končnega certifikata. Posamezni izpiti se vršijo v pooblaščenih izpitnih centrih, sestavljeni pa so iz časovno omejenih nalog, ki jih opravljajo kandidati s pomočjo računalnika.

Projekt iSkills, katerega nosilec je E TS (Education Testing Service) in je namenjen vsem državljanom, temelji na spoznanju, da so za delovanje $\mathrm{v}$ digitalni družbi potrebne tako tehnične kot tudi kognitivne spretnosti (Katz 2007). Okvir I K T-pismenosti po metodi iSkills je sestavljen iz sedmih tipov nalog, ki predstavljajo paleto raznolikih poti uporabe digitalnih informacij:

- opredelitev oziroma razumevanje in jasno oblikovanje raziskovalnega in problemskega vprašanja,

- dostopanje, kar vključuje zbiranje ali pridobivanje informacij v digitalnem okolju,

- vrednotenje oziroma presojo ustreznosti zbranih informacij po različnih kriterijih,

- upravljanje oziroma organiziranje pridobljenih virov za potrebe kasnejše uporabe,

- vključevanje oziroma sintezo, povzemanje in primerjavo zbranih virov,

- ustvarjanje oziroma spreminjanje, uporabo in oblikovanje informacij s pomočjo digitalnih orodij,

- komuniciranje oziroma razširjanje informacij med ciljnimi skupinami.

${ }^{20} \mathrm{Glej}$ http://www.certiport.com/portal/desktopdefault.aspx?TZ=1. 
Ocenjevanje poteka prek zaščitenih spletnih ocenjevalnih testov. V njih poteka simulacija različnih scenarijev $z$ uporabo 14 nalog, ki trajajo vsaka po 4 minute. Naloge se točkujejo. V modelu iSkills je moč doseči do 500 točk. Mednarodni odbor za osnovno raven I K T-pismenosti priporoča doseg vsaj 260 točk.

Nacionalni svet za kurikul in ocenjevanje (National Council for Curriculum and Assessment - N C CA) je, s ciljem, da bi pomagali učiteljem pri vključevanju I K T kot medpredmetne komponente pri vseh predmetih, določil znanja, veščine in odnos, ki se pričakujejo od učencev v osnovnih in nižjih srednjih šolah. Okvir je bil razvit kot pomoč pri načrtovanju učnih priprav učiteljev (National Council for Curriculum and Assessment 2004). Cilj te pobude je bil, da bi bili vsi učenci, ki zaključijo osnovno šolo, neodvisni učeči posamezniki, ki bodo sposobni samostojne in inovativne rabe IKT, učinkovitega komuniciranja, sodelovalnega dela ter kritične presoje, upravljanja in uporabe informacij.

Okvir NCCA je sestavljen iz štirih neodvisnih elementov, poimenovanih »učni cilji«, ki so sestavljeni iz 15 učnih rezultatov. Učenci preko 4 neodvisnih učnih ciljev dosegajo učne rezultate, ki jih prikazujemo v preglednici 2.2.

Okvir NCAA predvideva tri ravni digitalne pismenosti, ki so povezane s stopnjo izobraževanja otrok: nižjo osnovno raven, višjo osnovno raven in nižjo srednjo raven. ${ }^{21}$ Osnutek je bil predstavljen leta 2006 in popravljen leta 2007.

Tudi vlada Danske v okviru projekta Pedagoška I K T-licenca ponuja sedanjim in bodočim učiteljem možnost nadgradnje njihovih veščin rabe IKT in vključevanja IKT v procese poučevanja. Cilj projekta je uporaba I K T in medijev pri poučevanju ter učenju pri vseh predmetih. ${ }^{22}$ Tečaji, kjer lahko pridobijo I K T-licenco, so sestavljeni iz treh osnovnih in zaključnega modula:

- Osnovni moduli so pokrivali področja iskanja informacij na spletu, vnosa in urejanja besedila ter komunikacijsko-sodelovalne veščine.

- Zaključni modul pa pokriva področje novih metod poučevanja ob uporabi IKT.

Posamezna področja osnovnih in zaključnega modula vključujejo

${ }^{21}$ Glej http://ncca.ie/en/.

${ }^{22}$ Glej http://www.paedagogisk-it-koerekort.dk. 
Preglednica 2.2 Okvir digitalne pismenosti NCCA

\begin{tabular}{|c|c|}
\hline Učni cilj & Učni rezultat \\
\hline $\begin{array}{l}\text { Ustvarjanje, } \\
\text { komunikacija in } \\
\text { sodelovanje }\end{array}$ & $\begin{array}{l}\text { Učenec zna: } \\
\text { - izdelati osnutek, urejati in pregledati besedilo z uporabo I K T, } \\
\text { - ustvariti, zamenjati in vnesti informacije v različnih formatih } \\
\text { (slike, zvok, video), } \\
\text { - zbirati, organizirati, upravljati in analizirati podatke z uporabo } \\
\text { I KT, } \\
\text { - lokalno in globalno komunicirati in sodelovati z uporabo I KT, } \\
\text { - načrtovati, oblikovati, ustvarjati in predstaviti informacije z } \\
\text { uporabo I K T. }\end{array}$ \\
\hline $\begin{array}{l}\text { Razvijanje } \\
\text { osnovnih znanj, } \\
\text { veščin in } \\
\text { konceptov }\end{array}$ & $\begin{array}{l}\text { Učenec zna: } \\
\text { - prikazati in uporabiti funkcionalna znanja in razumevanje I K T, } \\
\text { - razvijati veščine za vzdrževanje in optimizacijo I KT, } \\
\text { - razumeti in poznati varno rabo I K T. }\end{array}$ \\
\hline $\begin{array}{l}\text { Kritično mišljenje } \\
\text { in ustvarjalnost }\end{array}$ & $\begin{array}{l}\text { Učenec zna: } \\
\text { - zbirati, dostopati in pridobivati informacije ob podpori I KT, } \\
\text { - vrednotiti, organizirati in graditi nove informacije z uporabo } \\
\text { I K T, } \\
\text { - ustvarjalno sestavljati nova znanja ob podpori I K T. }\end{array}$ \\
\hline $\begin{array}{l}\text { Razumevanje } \\
\text { socialnega in } \\
\text { osebnega vpliva } \\
\text { rabe I K T }\end{array}$ & $\begin{array}{l}\text { - Učenec razume in kritično presoja vloge I K T pri razvoju } \\
\text { posameznika in družbe, } \\
\text { - razvija neodvisno in sodelovalno učenja ter jezikovne veščine } \\
\text { ob uporabi I KT, } \\
\text { - razume pomen odgovorne in etične rabe IKT. }\end{array}$ \\
\hline
\end{tabular}

znanja iz obdelave slik, video- in avdio datotek, digitalnih virov, interaktivnih naprav in spletnih storitev.

Poučevanje učiteljev poteka prek seminarjev, ki so organizirani delno $\mathrm{v}$ živo in delno preko spleta. Ob zaključku seminarja učitelje testirajo, ti pa sestavijo tudi svoj digitalni razvojni listovnik.

Tudi projekt Informacijska pismenost na Škotskem, ki so ga vodili raziskovalci z Univerze v Glasgowu, je bil namenjen učečim z različnih izobraževalnih ravni: osnovne in srednje šole, univerze in vseživljenjskega izobraževanja (Irving 2010).

Okvir škotskega projekta Informacijska pismenost opredeli zahtevana znanja po posameznih ravneh izobraževanja:

- Osnovna šola: posameznik načrtuje, organizira, predstavlja in vrednoti pridobljene informacije.

- Srednja šola: posameznik opredeli ključne besede, določa ustreznost informacijskih virov, razume etično in odgovorno rabo, pozna načine komuniciranja in deljenja najdenih informacij. 
- Visokošolsko izobraževanje: posameznik prepozna potrebe po informacijah, gradi strategije lociranja informacij, jih zbira iz različnih virov in vrednoti, nadgrajuje obstoječe informacije in prispeva $\mathrm{k}$ ustvarjanju novega znanja.

- Vseživljenjsko učenje: posameznik razume potrebe po informacijah in njihovo razpoložljivost, pozna načine iskanja, vrednotenja, etične in odgovorne rabe, deljenja in upravljanja najdenih informacij.

Za vsako raven izobraževanja so prek opisnikov določena zahtevana znanja.

Zadnji preučevani okvir je U N E S C O V I K T-okvir kompetenc učiteljev. Okvir je, poleg učiteljem, namenjen tudi snovalcem izobraževalnih politik in izobraževalnim inštitucijam. Cilj projekta je bila izdelava mednarodnega standarda, namenjenega izobraževanju učiteljev pri usvajanju znanj s področja I K T in pri uvajanju IK T V poučevanje.

Cilje razvoja okvira delimo na 4 skupine (U N E S C O 2011):

- predstavitev smernic, ki izobraževalnim ustanovam pomagajo pri ugotavljanju obstoječega stanja, razvijanju in vrednotenju učnih gradiv, namenjenih izobraževanju učiteljev pri uporabi I K T v poučevanju in učenju,

- zagotovitev osnovnega nabora znanj, s pomočjo katerega bodo učitelji I K T lahko vključili v svoje poučevanje in na ta način spodbujali učenje,

- spodbuda strokovnemu razvoju učiteljev na pedagoškem področju, sodelovanju, vodenju in inovativnih učnih pristopih pri uporabi IKT,

- uskladitev različnih pogledov in pristopov, ki se nanašajo na uporabo I K T pri poučevanju.

Okvir I K T-pismenost za učitelje je matrična struktura, kjer so na eni strani določeni trije pristopi $\mathrm{k}$ izobraževalnim spremembam, in sicer:

- tehnološka pismenost,

- poglabljanje in

- ustvarjanje znanja.

Drugo stran matrike določajo sestavine izobraževalnega sistema, in sicer razumevanje rabe I K T v izobraževanju, kurikul in ocenjevanje, pedagogika, I K T, organizacija in administracija ter strokovni razvoj učite- 
Preglednica 2.3 UNESCO matrika IKT pismenosti učiteljev

\begin{tabular}{|c|c|c|c|}
\hline Sestavine/pristopi & $\begin{array}{l}\text { Tehnološka } \\
\text { pismenost }\end{array}$ & Poglabljanje znanja & Ustvarjanje znanja \\
\hline $\begin{array}{l}\text { Razumevanje rabe } \\
\text { IK T v } \\
\text { izobraževanju }\end{array}$ & $\begin{array}{l}\text { Zavedanje o } \\
\text { izobraževalni } \\
\text { politiki }\end{array}$ & $\begin{array}{l}\text { Razumevanje } \\
\text { izobraževalne } \\
\text { politike }\end{array}$ & $\begin{array}{l}\text { Inovacije } \\
\text { izobraževalne } \\
\text { politike }\end{array}$ \\
\hline $\begin{array}{l}\text { Kurikul in } \\
\text { ocenjevanje }\end{array}$ & Osnovno znanje & Uporaba znanja & $\begin{array}{l}\text { Družbeno-socialna } \\
\text { znanja }\end{array}$ \\
\hline Pedagogika & $\begin{array}{l}\text { Vključitev } \\
\text { tehnologije }\end{array}$ & $\begin{array}{l}\text { Reševanje } \\
\text { problemov }\end{array}$ & Samoorganiziranje \\
\hline IKT & Osnovna orodja & Kompleksna orodja & Prodorna orodja \\
\hline $\begin{array}{l}\text { Organizacija in } \\
\text { administracija }\end{array}$ & Običajni razred & $\begin{array}{l}\text { Sodelovalne } \\
\text { skupine }\end{array}$ & Učne organizacije \\
\hline $\begin{array}{l}\text { Strokovni razvoj } \\
\text { učitelja }\end{array}$ & $\begin{array}{l}\text { Digitalna } \\
\text { pismenost }\end{array}$ & $\begin{array}{l}\text { Organiziranje in } \\
\text { vodenje }\end{array}$ & $\begin{array}{l}\text { Učitelj kot učni } \\
\text { primer }\end{array}$ \\
\hline
\end{tabular}

lja (preglednica 2.3). Presek pristopa in komponente imenujemo modul okvira.

Namen okvira UNESCO je predvsem pomoč posameznim državam pri spremembah izobraževalnih politik in pri uvajanju IK T v poučevanje. Pri izobraževalnih reformah lahko država zagotovi uvajanje katere koli od treh ravni, odvisno od razpoložljivih sredstev in trenutnega stanja. Tehnološki pristop je primarni, osredotoča pa se predvsem na zagotovitev ustreznih pogojev za uvajanje I K T v izobraževalni proces. Pristop poglabljanja znanja spodbuja sodelovanje in reševanje problemskih situacij, medtem ko se pri procesu ustvarjanja znanja osredotočamo predvsem na ustvarjalnost in inovativnost ter uvajanje veščin 21. stoletja.

Okvir se ves čas dopolnjuje (zadnja različica je izšla novembra 2011), implementacija pa je $\mathrm{v}$ domeni izobraževalnih politik posameznih držav. 



\section{Modeli merjenja digitalne pismenosti}

V poglavju 2 smo spoznali 15 različnih okvirov merjenja digitalne pismenosti. Večina modelov se osredotoča na teoretični prikaz potrebnega znanja in veščin digitalne pismenosti ter ne vsebuje izdelanega inštrumentarija za ocenjevanje. Okviri, ki se merijo s testiranjem kandidatov, ob koncu izdajo certifikat uspešnosti, ki ga lahko posameznik uveljavlja v svoji mapi dosežkov (listovniku). V nadaljevanju prikazujemo tri modele, ki imajo izdelan inštrumentarij merjenja, zato jih pojasnjujemo podrobneje:

- okvir DCA, po katerem so merili digitalno pismenost pri italijanskih srednješolcih;

- okvir DIG COMP, ki je bil razvit pod okriljem Evropske komisije in je uradni okvir E U za merjenje digitalne kompetence; izdelani so tudi opisniki za področje izobraževanja;

- okvir ICILS, s pomočjo katerega se izvaja mednarodno merjenje računalniške in informacijske pismenosti.

\subsection{Model merjenja digitalne pismenosti D CA}

D CA oziroma »Digital Competence Assessment« je model ocenjevanja digitalne pismenosti, ki ga je v okviru projekta PR IN ${ }^{1}$ pripravila skupina raziskovalcev univerz iz Firenc, Torina, Casina in Salerna. Projekt je bil del pobude Internet in šola: vprašanja dostopnosti, politika enakomernosti in upravljanja informacij, ki ga je vodil Calvani z Univerze v Firencah. ${ }^{2}$

\subsection{Razvoj modela DCA}

V okviru projekta P RIN so želeli:

\footnotetext{
${ }^{1}$ Več na http://www.digitalcompetence.org/index.php/il-progetto/.

${ }^{2}$ Glej http://www.digitalcompetence.org/index.php/partners/.
} 
- raziskati vire in opredeliti socialno-kulturne in psihološke spremenljivke, ki vplivajo na dostop mladih do tehnologij, ter razviti teoretični model opredelitve pojma digitalne pismenosti,

- preučiti nacionalne in mednarodne vire $\mathrm{v}$ zvezi z vprašanji dostopa do I K T ter opredeliti ključne socialne, kulturne, tehnološke, kognitivne in etične veščine v konceptu digitalne pismenosti,

- razviti okvir ocenjevanja digitalne pismenosti za mladostnike, študente in učitelje,

- načrtovati in razviti digitalna e-gradiva, namenjena spodbujanju razvoja digitalne pismenosti v izobraževalnem procesu.

Avtorji modela v predstavitvi poudarjajo, da je pri digitalni pismenosti treba preusmeriti pozornost od predvsem tehničnega pogleda na kompleksnejše in pedagoško smiselnejše razumevanje, ki vključuje poznavanje osnovnih tehnoloških pojavov kot tudi znanja o etičnih in socialnih posledicah, povezanih z rabo spletnih tehnologij (Calvani, Fini in Ranieri 2010).

Pri pripravi koncepta digitalne pismenosti so upoštevali naslednja izhodišča:

- Večdimenzionalnost: digitalna pismenost posameznika je nelinearna povezava sposobnosti in spretnosti tehnološke, miselne, socialne in sorodne narave.

- Celovitost oziroma kompleksnost: digitalna pismenost ni popolno merljiva le $z$ enim testom. Nekatere vidike je težko meriti kratkoročno, saj zahtevajo več časa in uporabo različnih pristopov.

- Povezljivost: digitalna pismenost ni neodvisna od ostalih pismenosti, temveč se z njimi delno prekriva, kot npr. z branjem, reševanjem problemov, računanjem, logičnim mišljenjem in metakognitivnimi veščinami.

- Občutljivost na družbeno-kulturni kontekst: okvir digitalne pismenosti ni edinstven in ne ustreza merjenju v vsakem trenutku in okolju. Potrebno je upoštevati različne tudi izobraževalne in funkcionalne ravni.

Na podlagi izhodišč so avtorji digitalno pismenost opredelili kot sposobnost prilagodljivega raziskovanja novih tehnoloških potencialov. Digitalno pismen posameznik zbira, analizira in kritično vrednoti podatke ter informacije $z$ namenom reševanja problemov, sodelovanja, izgradnje 
Slika 3.1

Okvir digitalne pismenosti DCA

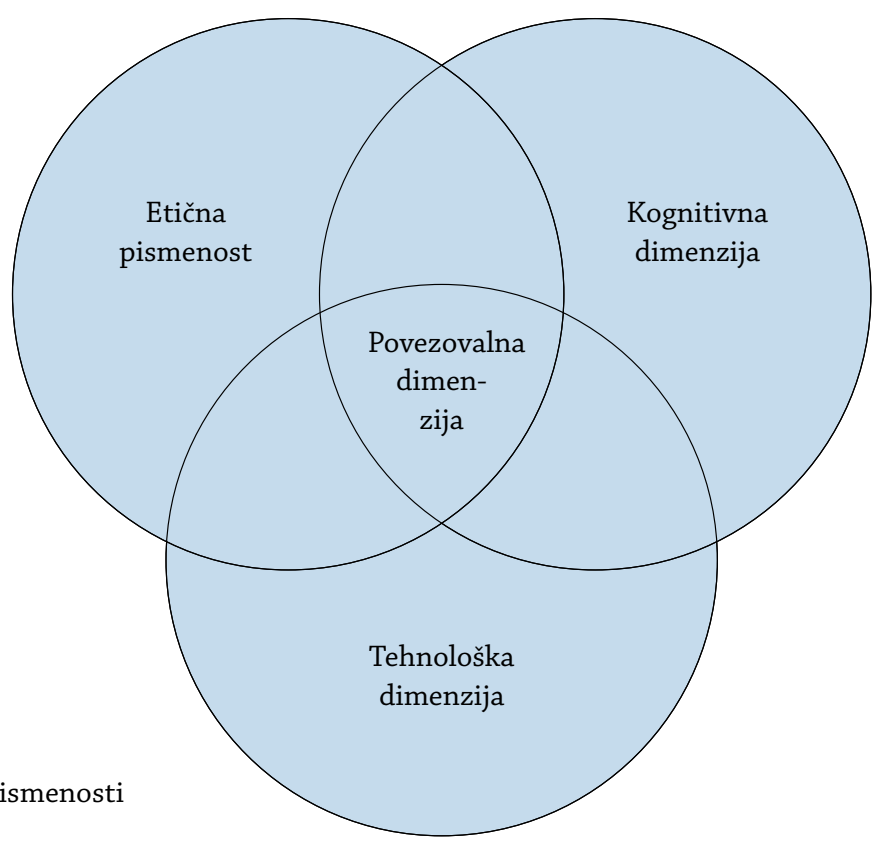

novih znanj in hkrati spodbujanja zavesti o osebni odgovornosti in spoštovanju pravic (Calvani idr. 2009).

\section{Okvir merjenja po modelu D CA}

Okvir vključuje naslednje dimenzije (slika 3.1):

- tehnološko: posameznik razume in vključuje sodobno tehnologijo pri reševanju problemov,

- kognitivno oziroma miselno: posameznik zbira, razlaga in vrednoti zbrane podatke ob upoštevanju njihove ustreznosti in zanesljivosti,

- etično: posameznik je sposoben konstruktivnega sodelovanja in občutka odgovornosti do sebe in drugih posameznikov,

- povezovalno: posameznik razume možnosti, ki jih nudijo nove tehnologije pri sodelovanju in izgradnji novih znanj.

Izhajajoč iz izhodišč in iz postavljenega modela DCA so avtorji razvili dva različna testa, in sicer iD CA (Instant Digital Competence Assessment) ter sDCA (Situated Digital Competence Assessment). iD CA je hiter kvantitativni test, ki se izvaja preko spleta in je bil osnova za merjenje digitalne pismenosti italijanskih srednješolcev. Predpogoj za 
pristop k preverjanju je bilo osnovno poznavanje tehnologije, zato se to znanje pri analizi ni preverjalo. Test SDCA je kompleksnejši in sestavljen iz nalog reševanja problemov. Izvaja se lahko le v prostorih $\mathrm{z}$ več računalniki, kjer sodelujoči s pomočjo računalnika sodelujejo v vodeni komunikaciji. Tako morata pri testiranju sodelovati najmanj dva udeleženca. V prvem delu testiranja (tehnološko raziskovanje) so udeleženci soočeni z nepoznanim uporabniškim vmesnikom programske opreme. Njihova naloga je raziskati in se naučiti uporabljati osnovne funkcije tega programa. $V$ naslednjem delu (simulacija) morajo na osnovi danih podatkov vzpostaviti možne povezave med njimi. Tretji del testa (preiskava) od udeležencev zahteva, da med množico danih virov le-te kritično ovrednotijo in izberejo informacije na določeno temo. Zadnji del testiranja (sodelovalni wiki) pa od udeležencev zahteva skupinsko pripravo dokumenta. $\mathrm{V}$ prvem delu testiranja se naloga opravlja $\mathrm{v}$ parih, vsi ostali deli pa zahtevajo skupinsko usklajevanje in delo prek deljenja skupnih dokumentov. Dijaki najprej dobijo seznam ciljev, ki jih morajo doseči, nato zahteve, ki jih morajo pri skupinskem delu upoštevati, in na koncu še predpogoje, ki jih morajo izpolniti za končno samoevalvacijo dela. Celotno njihovo delo opazuje in ocenjuje še zunanji ocenjevalec.

iD CA oziroma takojšnje merjenje digitalne pismenosti je instrument merjenja, ki upošteva različne vrste znanja in veščin (Calvani idr. 2012). $\mathrm{V}$ procesu razvoja okvira so vsa znanja in spretnosti natančno preučili in izpostavili naslednja znanja:

- vizualno pismenost, ki vključuje sposobnost prepoznavanja ikon, simbolov in uporabniških vmesnikov,

- reševanje problemov oziroma operativno znanje, ki pripomore k reševanju tehnoloških problemov; večina tega znanja izhaja iz praktičnih izkušenj,

- razumevanje tehnoloških konceptov oziroma znanje, povezano z delovanjem računalnikov in njihovim potencialom,

- etično znanje, ki vključuje znanje, potrebno za etično sprejemljiv način obnašanja; tu lahko govorimo tudi o znanju o varovanju zasebnosti, spoštovanju drugih in družbeno-kulturnem vplivu tehnologije.

Ob zapisanih vrstah potrebnih znanj so določili tudi nabor zahtevanih veščin, in sicer:

- organizacijo in povezovanje besedilnih in vizualnih podatkov, kar 
Preglednica 3.1 Naloge tehnološke dimenzije okvira DCA

\begin{tabular}{ll}
\hline Znanje & Naloga \\
\hline Vizualna pismenost & $\begin{array}{l}\text { Poznavanje pomena opozoril pri računalniku in } \\
\text { razumevanje orodnih vrstic. }\end{array}$ \\
\hline Reševanje problemov & $\begin{array}{l}\text { Odpravljanje težav z zvokom, delo z videodatotekami, } \\
\text { težave s tiskalnikom, nedelovanje računalnika, } \\
\text { morebitne težave zaradi okužbe z računalniškim } \\
\text { virusom. }\end{array}$ \\
\hline Razumevanje tehnoloških & $\begin{array}{l}\text { Poznavanje uporabe e-pošte, razlogi za nedostavo } \\
\text { konceptov }\end{array}$ \\
& $\begin{array}{l}\text { e-pošte, počasno delovanje interneta, povezovanje } \\
\text { med virtualno identiteto in človekom, iskanje s }\end{array}$ \\
& $\begin{array}{l}\text { pomočjo logičnih operatorjev ter zapis krajšega } \\
\text { algoritma. }\end{array}$ \\
\hline
\end{tabular}

vključuje veščino povezovanja in ustvarjanja semantičnih povezav ali pretvorbe podatkov v grafični prikaz in obratno,

- organiziranje strukture pridobljenih podatkov oziroma veščine, potrebne pri analiziranju ali obnavljanju podatkov, izgradnji struktur in hierarhij,

- iskanje informacij oziroma veščino kritičnega vrednotenja pridobljenih informacij.

Preverjanje okvira DCA oziroma iDCA se je izvajalo s pomočjo 85 vprašanj, povezanih s kratkimi nalogami, ki so jih glede na model razvrstili v posamezne dimenzije. $V$ tehnološko dimenzijo so bila vključena znanja s področja vizualne pismenosti, reševanja problemov, povezanih $\mathrm{z}$ delovanjem računalniške opreme, in razumevanje tehnoloških konceptov (preglednica 3.1).

V kognitivno področje so vključili veščine, povezane $\mathrm{z}$ organizacijo podatkov. Naloge v okviru kognitivne dimenzije prikazujemo v preglednici 3.2.

Etična dimenzija vključuje znanja s področja varovanja zasebnosti, spoštovanja drugih in razumevanja neenakosti. Naloge, ki so jih dijaki opravljali v okviru te dimenzije, prikazujemo v preglednici 3.3.

\section{Ocenjevanje digitalne pismenosti italijanskih srednješolcev}

Testiranje italijanskih srednješolcev po modelu DCA so, po predhodnem testiranju in preverjanju veljavnosti vprašanj, izvedli med septembrom 2009 in januarjem 2010. S testiranjem so želeli ugotoviti raven digitalne pismenosti. Glede na starostno skupino (t.i. digitalni domo- 
3 Modeli merjenja digitalne pismenosti

Preglednica 3.2 Naloge kognitivne dimenzije okvira DCA

\begin{tabular}{ll}
\hline Veščina & Naloga \\
\hline $\begin{array}{l}\text { Organizacija in } \\
\text { povezovanje besedilnih in } \\
\text { vizualnih podatkov }\end{array}$ & $\begin{array}{l}\text { Predstavitev besedila z grafikonom, predstavitev } \\
\text { hierarhije podatkov, hierarhična struktura dokumenta } \\
\text { in določanje ključnih besed v besedilu. }\end{array}$ \\
\hline $\begin{array}{l}\text { Organiziranje strukture } \\
\text { pridobljenih podatkov }\end{array}$ & $\begin{array}{l}\text { Organiziranje podatkov v tabele, iskanje manjkajoče } \\
\text { vrednosti v tabeli in načrtovanje enostavnega } \\
\text { proračuna. }\end{array}$ \\
\hline $\begin{array}{l}\text { Iskanje informacij } \\
\text { Preglednica 3.3 Naloge etične dimenzije okvira D cA }\end{array}$ \\
\hline Znanje & Naloga \\
\hline Varovanje zasebnosti & $\begin{array}{l}\text { Objavljanje zasebnih podatkov na spletu in spletno } \\
\text { plačevanje }\end{array}$ \\
\hline Spoštovanje drugih & $\begin{array}{l}\text { Sovražni govor in citiranje informacij, najdenih na } \\
\text { spletu }\end{array}$ \\
\hline $\begin{array}{l}\text { Razumevanje družbene in } \\
\text { tehnološke neenakosti }\end{array}$ & $\begin{array}{l}\text { Zavest o tehnološkem iskanja, } \\
\text { državami }\end{array}$ \\
\hline
\end{tabular}

rodci) so predvidevali, da bodo rezultati visoki, zato so prag uspešnosti postavili na $75 \%$.

Šole so bile k sodelovanju pozvane naključno glede na regijo in glede na vrsto srednješolskega programa. Vzorec je vključeval 1.056 dijakov iz 34 šol, povprečna starost dijaka pa je bila 15 let.

Uspešnost reševanja vprašalnika je bila nižja od pričakovane, saj je bil povprečen rezultat $62,5 \%$, le $24 \%$ dijakov pa je doseglo zahtevani prag uspešnosti $-75 \%$. Natančnejša analiza je pokazala, da so dijaki prag uspešnosti v povprečju dosegli le na tehnološkem področju, medtem ko so na kognitivnem in etičnem, na vseh preverjanih ravneh znanja in veščin, v povprečju dosegli nižje rezultate. Nadaljnje preučevanje doseženih znanj in veščin pokaže, da bi glede na rezultat kot digitalno pismenega dijaka lahko označili le posameznika, ki je sposoben prepoznati najbolj uporabljene simbole in ikone ter ima veščino reševanja osnovnih tehničnih problemov $\mathrm{v}$ zvezi z delovanjem računalnika.

Bolj zaskrbljujoči so bili rezultati na kognitivnem in etičnem področju, kjer npr. kar 1/3 dijakov ne pozna razloga za nedelujočo e-pošto ali posledic okužbe $\mathrm{z}$ računalniškim virusom. Tudi pri ključnih aktivnostih miselnih procesov, kot so upravljanje besedilnih podatkov, hierarhično strukturiranje informacij, prepoznavanje ključnih besed in interpreta- 
cija grafikonov, so v povprečju dosegli manj kot 70-odstotno pravilnost odgovorov. $60 \%$ dijakov napačno razume rezultate spletnih iskalnikov, več kot $50 \%$ vprašanih pa ne pozna kriterijev prikazanih rezultatov iskanja. Posebej zanimivi so bili rezultati na etičnem področju. Zanimivo je, da večina vprašanih spletno trpinčenje označuje kot nesprejemljivo, ne pozna pa pravil varne rabe interneta in zasebnosti na spletu. Študija je pokazala tudi, da večina vprašanih ne razume t.i. tehnološke vrzeli med razvitim svetom in državami s slabo razvito infrastrukturo.

Rezultati testiranj so pokazali, da ima šola oziroma proces izobraževanja ključno vlogo pri vpeljevanju IK T v poučevanje in učenje otrok. Pomembno je spoznanje, da IKT ne sme biti označena le kot orodje, temveč se morajo hkratno razvijati in vpeljevati tudi sodobne učne metode, ki podpirajo delo s pomočjo tehnologije. Mladi morajo znanja usvajati spontano prek praktičnih primerov in v navezi $\mathrm{z}$ razvojem ostalih veščin, saj bodo le tako lahko postali dovolj kognitivno, etično in socialno zavedni posamezniki (Buckingham 2007).

\subsection{Model merjenja digitalne pismenosti D I G C O M P}

DIG COMP je okvir (Ferrari, Punie in Brečko 2013) za razvijanje in razumevanje digitalne kompetence v Evropi, ki je bil razvit pod okriljem Evropske komisije. Kot smo že omenili, je digitalna kompetenca ena od osmih ključnih kompetenc za vseživljenjsko učenje (Ala-Mutka, Punie in Redecker 2008), hkrati pa je transverzalna kompetenca, saj omogoča doseganje ostalih ključnih kompetenc, kot so jezikovna in matematična kompetenca, učenje učenja ter kulturna zavest. Evropski okvir digitalne kompetence DIGCOMP se lahko uporablja v različnih kontekstih, opisniki posameznih kompetenc pa so trenutno razviti le za področje izobraževanja.

\section{Cilji in sestava okvira DIG COMP}

Cilj razvoja enotnega okvira digitalnih kompetenc je usmerjen $\mathrm{k}$ različ́nim uporabnikom:

- državljanom z nizko sposobnostjo uporabe I K T v vsakdanjem življenju okvir pomaga zagotovili bistvene veščine za izboljšanje njihovega osebnega in poklicnega življenja,

- iskalcem zaposlitve pomaga zagotovili bistvene veščine za identifikacijo njihovih znanj in odkrivanje pomanjkljivosti njihovega znanja s ciljem nadaljnjega izobraževanja, 
- zaposlovalcem pomaga opredeliti nabor znanj, veščin in usposobljenosti, ki jih zahtevajo sodobna delovna mesta,

- zavodom za zaposlovanje pomaga zagotovili bistvene veščine za izmenjevanje pomembnih informacij na trgu dela in ustrezno poklicno usmerjanje,

- izobraževalnim ustanovam in ustanovam za vseživljenjsko učenje je v pomoč pri pripravi njihovih izobraževalnih načrtov.

Evropska komisija prek izvajanja projektov, dogodkov in delovnih skupin spodbuja vključevanje okvira DIG COMP v njihovo delo. Okvir DIGCOMP bo uporabljen tudi kot osnova za razvoj okvira digitalnih kompetenc posameznih ciljnih skupin, kot so npr. učitelji in potrošniki, za samoevalvacijo pridobljenih digitalnih veščin in tudi za potrebe evropske statistike (indikator digitalnih veščin v okviru Digital Agenda Scoreboard). ${ }^{3}$

Okvir DI G COMP je sestavljen iz 5 sestavin: kompetenc in (pod)kompetenc posameznega področja, nivoja zmožnosti, ki so predvidene za posamezno kompetenco, primerov znanj, veščin in stališč ter primerov uporabe kompetenc za določen namen.

Kompetence so razdeljene na 5 področij (Ferrari idr. 2013):

- Informacije: posameznik je sposoben najti želeni nabor informacij, jih shraniti in povezovati, organizirati ter analizirati. Vse dobljene informacije kritično vrednoti po relevantnosti, kakovosti in zanesljivosti.

- Komunikacija: posameznik s pomočjo razpoložljivih spletnih orodij komunicira in se povezuje $z$ drugimi, izmenjuje vsebine in sodeluje v spletnih skupnostih.

- Ustvarjanje vsebin: posameznik je sposoben ustvarjanja in urejanja novih vsebin različnih formatov (besedilo, slike, video, avdio). Ustvariti zna kreativne medijske vsebine, hkrati pa spoštuje avtorske pravice drugih uporabnikov.

- Varnost: posameznik je sposoben poskrbeti za osebno zaščito digitalne identitete in varovanja podatkov. Pozna osnovne ukrepe varne rabe interneta in ga smiselno uporablja.

- Reševanje problemov: posameznik je sposoben reševati konceptualne in tehnične probleme prek smiselne rabe najprimernejšega di-

\footnotetext{
${ }^{3}$ Več na http://digital-agenda-data.eu/datasets/desi/indicators.
} 
gitalnega orodja. Zna ugotoviti raven potreb po virih in svoje kompetence nadgrajuje.

Podrobne opisnike za posamezno področje in pripadajoče kompetence prikazujemo v prilogi 1. Vsako kompetenco je možno doseči na treh nivojih, in sicer kot:

- temeljno zmožnost,

- vmesno zmožnost in

- napredno zmožnost.

Za vsako kompetenco so zapisani primeri znanj, veščin in stališč, ki pa niso razvrščeni po nivojih zmožnosti. V okviru D IG C OM P so podani še primeri rabe posamezne kompetence za določen namen - učenje, prosti čas, socialo, nakupovanje, prodajo, zaposlovanje, državljanstvo in dobro počutje. Primer zapisa vseh vidikov za kompetenco "Sodelovanje s pomočjo tehnologije« je predstavljen v prilogi 1.

\section{Uporaba okvira DI G COMP pri državah članicah E U}

Nekatere države, članice Evropske unije, že uporabljajo okvir D I G C O M P in izpeljano somoocenjevalno orodje pri izobraževalnih reformah, vpeljavah v izobraževalne načrte ali pri usposabljanju učiteljev. Cilj razvoja okvira digitalnih kompetenc je v boljšem razumevanju pomena razvoja in v vsakodnevni rabi, kot je npr. spremljanje ravni digitalne pismenosti vseh državljanov.

Okvir D I G C O M P so v svoj razvoj vključile različne organizacije in regije (European Commision 2014):

- Španija, Navarra: oddelek za izobraževanje uporablja okvir DIGCOMP kot ključno referenco strateškega načrtovanja razvoja,

- Španija, Baskija: projekt Ikanos, Vlada pokrajine Baskije je pripravila brezplačno spletno ocenjevalno orodje ravni digitalne pismenosti s pomočjo okvira DIG COMP,

- Španija, Ministrstvo za izobraževanje: inštitut inte F uporablja okvir DogComp za razvoj izobraževanj učiteljev,

- Malta, Ministrstvo za izobraževanje in zaposlovanje: uporaba okvira DIG COMP pri izobraževalni reformi,

- Belgija, Flandrija: uporaba okvira DIG COMP pri izobraževalni reformi in pri razvoju izobraževanja odraslih,

- Estonija: prevod okvira DIGCOMP, 
- Generalni direktorat E K za pravosodje in potrošnike: razvoj okvira digitalne pismenosti za potrošnike,

- Projekta CareNet in Care+: izgradnja IK T-kompetenc v sektorju nege in v starostni skupini nad 65 let,

- Slovenija: prevod okvira in uporaba pri izgradnji samoocenjevalnega orodja v okviru projekta E-šolska torba.

\subsection{Model merjenja računalniške in informacijske pismenosti ICILS}

Raziskavo računalniške in informacijske pismenosti IC ILS (International Computer and Information Literacy Study) koordinira Mednarodna organizacija za evalvacijo izobraževalnih dosežkov IE A (International Association for Evaluation of Educational Achievement). V I E A so včlanjene inštitucije iz več kot 60 držav sveta, ki skupaj izvajajo raziskave na področju izobraževanja.

V raziskavo IC IL S 2013 je bilo včlanjenih 21 izobraževalnih sistemov. Prvič je v njej sodelovala tudi Slovenija, kjer je bilo vključenih 219 šol (3.740 učencev, 2.787 učiteljev, I K T-koordinatorji in ravnatelji). Poleg Slovenije je sodelovalo še 8 držav iz E U (Hrvaška, Češka, Danska, Nemčija, Litva, Nizozemska, Slovaška in Poljska) ter Avstralija, Argentina, Čile, Hong Kong, Koreja, Kanada, Norveška, Rusija, Švica, Tajska in Turčija.

\section{Okvir merjenja računalniške in informacijske pismenosti CIL}

$\mathrm{Z}$ raziskavo ICILS so želeli preveriti računalniško in informacijsko pismenost (angl. Computer and Information Literacy - C IL) učencev oziroma njihovo sposobnost uporabe računalnika za raziskovanje, ustvarjanje in sporazumevanje s ciljem učinkovitega sodelovanja doma, v šoli, na delovnem mestu ali v skupnosti. Poleg tega so želeli raziskati tudi poti, po katerih mladi razvijajo sposobnosti uporabe računalnika in interneta kot zmožnost za sodelovanje $\mathrm{v}$ digitalni dobi.

Ciljna skupina raziskave so bili osmošolci s povprečno starostjo 13,5 let. V raziskavo so iz posamezne šole vključili do 20 naključno izbranih učencev. Kot posebno skupino preučevane populacije so iz vsake šole izbrali še 15 učiteljev, ki so učili učence preučevane skupine, ter ravnatelja in I K T koordinatorja izbrane šole.

Instrumentarij merjenja je bil razdeljen na različna področja in je vseboval več različnih vprašalnikov: 
- Mednarodni test za učence, ki je vseboval vprašanja in naloge, s katerimi so merili stopnjo računalniške in informacijske pismenosti. Test se je izvajal s pomočjo računalnika.

- Vprašalnik, s katerim so preučevali vidike osebnih in socialnih okolij učencev ter merili njihov odnos do rabe IK T.

- Vprašalnik za učitelje je zbiral podatke o znanju rabe I K T pri poučevanju in odnosu do rabe I K T pri poučevanju in učenju.

- Vprašalnik za ravnatelje je omogočil zbiranje podatkov o značilnosti v raziskavo vključenih šol. Pri tem so se zbirali predvsem podatki o vključevanju IK T v poučevanje in upravljanju I K T v izbranih šolah.

- S pomočjo vprašalnika za IKT-koordinatorje so zbirali podatke o opremljenosti šol z IK T in podpori učiteljem pri rabi IKT.

- $\mathrm{Z}$ vprašalnikom na nacionalni ravni so, s pomočjo nacionalnih raziskovalnih centrov, zbrali podatke o izobraževalnih sistemih preučevanih držav in izobraževalni politiki glede vprašanj rabe I K T.

Merjenje računalniške in informacijske pismenosti je bilo zasnovano $\mathrm{v}$ dveh sklopih, ki sta obsegala potrebne veščine in znanja $\mathrm{v}$ okviru modela CIL (Fraillon idr. 2014):

1. Sklop 1. okvira ICILS se je osredotočal na dosledno in organizirano upravljanje informacij. Pri tem so bili vključeni naslednja znanja in veščine:

- razumevanje zmožnosti rabe računalnika: posameznik pozna splošne značilnosti in funkcije računalnika, osredotoča se na osnovna tehnična znanja in veščine, ki so potrebni za delo z informacijami,

- dostopanje in vrednotenje pridobljenih informacij: vključuje zmožnost posameznika za iskanje, pridobivanje in vrednotenje pridobljenih informacij, pri čemer se presoja ustreznost, celovitost in uporabnost računalniških informacij,

- upravljanje informacij: zmožnost posameznika za delo z računalniško pridobljenimi informacijami. Posameznik naj bi bil zmožen klasificirati informacije v organizirane sheme, ki omogočajo urejanje, hranjenje in ponovno uporabo.

2. Sklop 2. okvira ICILS se je osredotočal na uporabo računalnika kot orodja za ustvarjanje, komuniciranje in razmišljanje. Sestavljen je bil iz naslednjih znanj in veščin: 
- preoblikovanja informacij: zmožnost posameznika, da s pomočjo računalnika spremeni način predstavitve pridobljenih informacij in jih prilagodi ciljni skupini uporabnikov,

- ustvarjanja informacij: zmožnost posameznika, da ustvari in oblikuje informacije za posamezne ciljne skupine, ki so lahko popolnoma nove ali pa so sestavljene in nabora drugih informacij in tako predstavljajo nov nabor znanja,

- deljenja informacij: zavedanje o zmožnostih uporabe računalnika za komuniciranje in izmenjevanje informacij z drugimi uporabniki,

- varne rabe informacij: razumevanje posameznika o legalnih in etičnih težavah, ki lahko nastopijo pri prejemniku ali pošiljatelju ob komuniciranju s pomočjo računalnika.

Ocenjevanje po modelu I c I L s je temeljilo na štirih modulih, ki so bili sestavljeni iz nabora vprašanj in nalog (Fraillon idr. 2015):

- domače vaje: naloga je bila sestavljena tako, da so za učence pripravili sodelovalno okolje, kjer so lahko delili informacije in skupaj ustvarili promocijski plakat za program spodbujanja domačih vaj,

- tekmovanje glasbenih skupin: učenci so morali načrtovati postavitev spletne strani, urejati slikovni material in uporabiti enostavno orodje za ustvarjanje spletnih strani s ciljem informiranja javnosti o tekmovanju glasbenih skupin,

- dihanje: naloga učencev je bila urejanje dostopnih datotek in zbiranje ter vrednotenje informacij, ki so potrebne za izdelavo predstavitve procesa dihanja ciljne skupine od 8 do 9 let starih otrok,

- šolski izlet: učenci so načrtovali šolski izlet $\mathrm{z}$ uporabo spletnega orodja za baze podatkov, pri čemer je bila njihova naloga izbira in prilagoditev informacij za izdelavo navodil o izletu za njihove vrstnike; navodila so morala vključevati zemljevid poti, ki so ga izdelali s pomočjo spletne storitve.

Vsak test je bil sestavljen iz kombinacije dveh modulov; možnih je bilo 12 različnih kombinacij. Točke so bile razporejene na skali, katere srednja vrednost je bila 500 (standardni odklon 100). Končni rezultati so bili razporejeni na štiri ravni računalniške in informacijske pismenosti učenca.

Točkovnik ravni, znanja in veščin, ki so jih dosegli anketiranci, uvrščeni v posamezno raven, prikazujemo $\mathrm{v}$ prilogi 2. 


\section{Rezultati merjenja I C I L S 2013}

V mednarodni raziskavi računalniške in informacijske pismenosti IC IL S 2013 je sodelovalo 60.000 učencev, 35.000 učiteljev, 3.300 šol in 21 izobraževalnih sistemov. Povprečje doseženih točk vključenih držav je bilo razporejeno na skali s srednjo vrednostjo 500, kar izkazuje 2. raven računalniške in internetne pismenosti (priloga 2). Glavni kazalniki nam povedo, da je $99 \%$ preučevanih šol priključenih na internetno omrežje, vendar so med njimi precejšnje razlike. Na Norveškem imata v povprečju vsaka dva učenca en računalnik, medtem ko v Turčiji 80 učencev uporablja en računalnik. $36 \%$ učencev je računalnik uporabljajo že pred vstopom v izobraževalni sistem, $89 \%$ jih je prepričanih, da lahko uspešno najdejo informacije na internetu, a hkrati jih le $2 \%$ kritično presoja pridobljene informacije. ${ }^{4}$

$\mathrm{V}$ povprečju je $84 \%$ učencev doseglo vsaj 1. raven računalniške in informacijske pismenosti (največ: $98 \%$ Češka republika in $95 \%$ Norveška), ki je obsegala osnovno poznavanje računalnika in programske opreme. Drugo raven, kjer je bilo treba prikazati znanje in veščine uporabe računalnika kot orodja za učinkovito iskanje informacij, je doseglo v povprečju $61 \%$ učencev ( $85 \%$ Češka republika, 76 \% Avstralija).

Napredno znanje in veščine rabe IK T kot orodja za zbiranje in uporabo informacij (3. raven) je doseglo le $23 \%$ učencev (Češka republika $37 \%$, Koreja $35 \%$ ), medtem ko je najvišjo, 4. raven, ki je obsegala znanje in veščine kritičnega vrednotenja dobljenih informacij, doseglo $\mathrm{v}$ povprečju le $2 \%$ učencev (Koreja $5 \%$, Avstralija in Poljska 4\%).

$87 \%$ učencev uporablja računalnik tudi doma, medtem ko ga $v$ šoli uporablja v povprečju le dobra polovica učencev ( $54 \%$ ). Najpogostejše aktivnosti pri rabi računalnika doma so komuniciranje s prijatelji prek uporabe družabnih omrežij (75\%), iskanje informacij za potrebe šolskih obveznosti ( $52 \%)$ in komentiranje zapisov, objavljenih v spletnih dnevnikih (49\%).

Pri raziskavi učiteljev jih je kar $84 \%$ izjavilo, da uporabljajo računalnik več kot dve leti. Zanimiv podatek je, da jih $46 \%$ svoje znanje s področja rabe IK T pridobiva tako, da opazujejo druge učitelje pri njihovem delu, le $33 \%$ pa z udeležbo na izobraževalnih seminarjih. Manj kot $50 \%$ učiteljev svoje znanje s področja rabe IK T pri poučevanju ocenjuje za zadostno. Med aktivnostmi, ki jih obvlada večina učiteljev, so iskanje

\footnotetext{
${ }^{4}$ Glej http://www.iea.nl/fileadmin/user_upload/Studies/ICILS_2013/ICILS_2013 _infographic.pdf.
} 
učnih virov na internetu, uporaba urejevalnika besedil in pošiljanje priponk z e-pošto. Učitelji se manj sposobne čutijo pri aktivnostih nameščanja programske opreme, sodelovanja $\mathrm{z}$ drugimi in udeležbi v spletnih forumih. Le $4 \%$ učiteljev uporablja družabna omrežja, $3 \%$ programsko opremo za izvajanje raznih simulacij in $5 \%$ digitalne učne igre.

Med preučevanimi izobraževalnimi sistemi jih je 18 od $21 \mathrm{v}$ svoje izobraževalne politike že vključilo rabo I K T pri poučevanju in učenju. Med glavnimi aktivnostmi teh politik so izobraževanje učiteljev za rabo I K T, uporaba sistemov za upravljanje učnih vsebin in obveščanje staršev $\mathrm{s}$ pomočjo IKT.

Slovenski učenci so v raziskavi ICILS 2013 dosegli v povprečju 511 točk, s čimer so se uvrstili med 7. in 10. mestom na mednarodni lestvici. Razen dveh izstopajočih držav (Turčija in Tajska) se večina dosežkov učencev uvršča v drugo zahtevnostno raven (v Sloveniji je takih učencev $47 \%$ ), v četrto, najzahtevnejšo raven pa se je uvrstilo le $0,4 \%$ slovenskih učencev. Pod prvo zahtevnejšo ravnjo je $8 \%$ slovenskih učencev, medtem ko se mnoge države dosegle še bistveno slabši rezultat (Tajska in Turčija prek $60 \%$, Čile $18 \%$, Litva $15 \%$ in Hrvaška 11\%) (Pedagoški inštitut 2014).

Ob merjenju računalniške in informacijske pismenosti so raziskovali tudi vpliv številnih dejavnikov, kot so npr. socialno-ekonomski status, spol, izkušnja učencev $\mathrm{z}$ rabo računalnikov doma in $\mathrm{v}$ šoli, pogostost rabe I K T doma, pričakovana stopnja izobrazbe učencev, izobrazba staršev, število knjig doma, poklicni status staršev in uporaba I K T za zabavo.

Primerjava po spolu je pokazala, da so dekleta v povprečju dosegla za 18 točk boljši rezultat kot fantje (med evropskimi državami je bila največja razlika v prid deklet ravno v Sloveniji, in sicer 29 točk) (Fraillon idr. 2014).

Posebej zanimivi so rezultati, kjer so primerjali pričakovano raven izobrazbe $z$ doseženimi rezultati. Učenci, ki nameravajo pridobiti univerzitetno izobrazbo, so v povprečju dosegli 527 točk, medtem ko so učenci s pričakovano poklicno izobrazbo (439 točk) ali srednjo strokovno izobrazbo (466 točk) dosegli precej nižji rezultat. Podobni rezultati so tudi v primerjavi doseženih rezultatov $\mathrm{z}$ ravnjo izobrazbe staršev anketiranih učencev. Učenci, katerih starši imajo vsaj univerzitetno izobrazbo, so dosegli za $16 \%$ boljše rezultate kot učenci, katerih starši imajo poklicno izobrazbo.

Primerjava doseženih rezultatov učencev, ki imajo v domačem oko- 
lju več kot 100 naslovov različnih knjig (povprečni rezultat 526 točk), je pokazala, da dosegajo boljše rezultate kot učenci, ki imajo doma manj kot 10 knjig (povprečni rezultat 453 točk). 



\section{4 Šolski sistem in gimnazija v sistemu vzgoje in izobraževanja}

Cilj sistema vzgoje in izobraževanja v Sloveniji je zagotavljanje optimalnega razvoja posameznika. $Z$ izvajanjem javno veljavnih programov ga uresničujejo javni in zasebni zavodi ter zasebniki s koncesijo. Vodenje izobraževalnih politik in priprava sistemskih predpisov je v pristojnosti Ministrstva za izobraževanje, znanost in šport (M I žs) (Taštanoska, Žgank in Pal 2014).

Pri sprejemanju strokovnih odločitev načrtovanja in vodenja izobraževalne politike ter pri pripravi predpisov in nacionalnih programov $\mathrm{z}$ M IZŠ sodelujejo strokovni sveti, ki jih ustanovi vlada, in sicer:

- Strokovni svet RS za splošno izobraževanje,

- Strokovni svet RS za poklicno in strokovno izobraževanje,

- Strokovni svet RS za izobraževanje odraslih in

- Svet RS za visoko šolstvo.

Sistem vzgoje in izobraževanja v RS obsega (Černoša 2012):

- predšolsko vzgojo,

- osnovnošolsko izobraževanje,

- srednješolsko izobraževanje,

- višje strokovno izobraževanje in

- visokošolsko izobraževanje.

Srednješolsko izobraževanje se lahko izvaja kot nižje in srednje poklicno izobraževanje, srednje strokovno in tehniško izobraževanje ali srednje splošno izobraževanje. Visokošolsko izobraževanje se izvaja na treh stopnjah. Na prvi bolonjski stopnji se izvajajo visokošolski strokovni in univerzitetni študijski programi, na drugi stopnji magistrski študijski programi in na tretji stopnji doktorski študijski programi.

\subsection{Srednješolsko izobraževanje v Sloveniji}

Srednješolsko izobraževanje je nadaljevanje obveznega osnovnošolskega izobraževanja in traja od 2 do 5 let. Vanj vstopajo generacije, stare 
praviloma 15 let. Srednješolsko izobraževanje je urejeno z naslednjimi zakoni: $^{1}$

- Zakon o organizaciji in financiranju vzgoje in izobraževanja (Uradni list Republike Slovenije, št. 16/o7 - U P B in 36/o8),

- Zakon o gimnazijah (Uradni list Republike Slovenije, št. 1/o7- U P B),

- Zakon o poklicnem in strokovnem izobraževanju (Uradni list Republike Slovenije, št. 79/o6),

- Zakon o maturi (Uradni list Republike Slovenije, št. 1/o7 - U P B),

- Zakon o posebnih pravicah italijanske in madžarske narodne skupnosti na področju vzgoje in izobraževanja (Uradni list Republike Slovenije, št. 35/o1 in 102/o7 - Z O sn-F) in

- Zakon o usmerjanju otrok s posebnimi potrebami (Uradni list Republike Slovenije, št. 3/o7 - U P B).

Srednješolsko izobraževanje se deli na:

- splošno izobraževanje, kamor spadajo štiriletni programi splošne in strokovne gimnazije (gimnazija in klasična gimnazija, ekonomska, tehniška in umetniška gimnazija) in enoletni maturitetni tečaj;

- poklicno in strokovno izobraževanje, kamor spadajo programi nižjega (2 leti), srednjega poklicnega (3 leta), srednjega strokovnega (4 leta) in poklicno-tehniškega $(3+2$ leti) izobraževanja ter poklicni tečaj (1 leto).

Sistem srednjega šolstva je centraliziran, saj se o ustanavljanju in financiranju šol ter razmeščanju izobraževalnih programov odloča na nacionalni ravni. Konkretizacija učnih vsebin, izbira metod poučevanja, kadrovanje in urejanje delovnih razmerij pa so $\mathrm{v}$ domeni posamezne šole in učiteljev.

Srednješolsko izobraževanje je v šolskem letu 2013/2014 izvajalo 110 javnih srednjih šol, organiziranih kot enovite srednje šole ali šolski centri, ter 6 zavodov za mladostnike s posebnimi potrebami. ${ }^{2}$ Ob koncu šolskega leta 2014/2015 je bilo v srednješolske izobraževalne programe vpisanih 73.652 dijakov in 17.793 odraslih. Izmed vseh vpisanih je bilo

\footnotetext{
${ }^{1}$ Glej http://www.mizs.gov.si/si/delovna_podrocja/direktorat_za_srednje_in_visje _solstvo_ter_izobrazevanje_odraslih/srednjesolsko_izobrazevanje/.

${ }^{2}$ Glej http://www.mizs.gov.si/si/delovna_podrocja/direktorat_za_srednje_in_visje _solstvo_ter_izobrazevanje_odraslih/srednjesolsko_izobrazevanje/vpis_v_srednje _sole/vpis_201314/.
} 
$38 \%$ dijakov vpisanih v splošno izobraževanje, med njimi je bilo $59 \%$ deklet.

Namen srednješolskega splošnega izobraževanja je priprava na nadaljevanje študija na univerzah. Vsi gimnazijski programi vsebujejo obvezni in izbirni del. Med obvezne štiriletne predmete sodijo slovenski jezik, matematika, prvi in drugi tuji jezik, zgodovina in športna vzgoja. Med obvezne predmete sodijo še glasba, likovna umetnost, geografija, biologija, kemija, fizika, psihologija, sociologija, filozofija in informatika. Ure za izbirne predmete so razporejene od drugega do zadnjega letnika, namenjene pa so predvsem pripravi na maturo.

\subsection{Posodobitev gimnazijskih programov}

Z ustanovitvijo pristojnih komisij se je v letu 2006 začelo formalno posodabljanje kurikula kot nadgradnja prenove iz leta 1998. Na podlagi 16. člena Zakona o državni upravi (Uradni list Republike Slovenije, št. 24/o5 - U P B3) je minister imenoval komisijo za spremljanje in posodabljanje učnih načrtov in katalogov znanj za področje splošnega izobraževanja in splošno-izobraževalnih znanj v poklicnem izobraževanju. Za izvedbo nalog državne komisije je Zavod RS za šolstvo (zRSŠ) imenoval predmetne komisije ${ }^{3}$ za spremljanje in posodabljanje učnih načrtov za posamezne predmete.

Strokovni svet za splošno izobraževanje je v letu 2007 sprejel gradivo $\mathrm{z}$ naslovom "Izhodišča prenove gimnazijskega programa«, ki ga je pripravila Komisija za pripravo koncepta nadaljnjega razvoja gimnazijskega programa. Med izhodišča so zapisali naslednja:

- avtonomija šole in učitelja,

- odprtost in izbirnost,

- odgovornost za lastno znanje,

- razvijanje kompetenc in kompetenčni pristop,

- integrativni kurikul,

- razvoj pismenosti - pot do funkcionalnih znanj,

- aktualizacija ciljev in vsebin,

- celostni pristop in interdisciplinarno povezovanje ter

\footnotetext{
${ }^{3}$ Imenovanih je bilo 27 predmetnih komisij za splošne predmete, 6 komisij za splošna področja, 21 predmetnih komisij za strokovne predmete v tehniški gimnaziji, 11 predmetnih komisij za strokovne predmete v umetniški gimnaziji, dramska smer in 6 predmetnih komisij za strokovne predmete v umetniški gimnaziji, likovna smer.
} 
- učno-ciljni in procesno-razvojni pristop k načrtovanju.

MIZŠ je za obdobje 2008-2014 razpisal projekt »Posodobitev gimnazijskih programov«, v katerega so se slovenske gimnazije vključile v okviru konzorcijev splošnih in strokovnih gimnazij. ${ }^{4}$ Sodelovalo je 56 splošnih gimnazij in 31 strokovnih gimnazij. Razvojni prioriteti projekta sta bili razvoj človeških virov in vseživljenjskega učenja ter izboljšanje kakovosti in učinkovitosti sistemov izobraževanja ter usposabljanja. Strokovno podporo projektu sta nudila Urad za razvoj izobraževanja in ZRSš, delno pa se je projekt financiral s sredstvi Evropskega socialnega sklada (E SS). Projekt posodobitve gimnazijskih programov je obsegal tri večje sklope, in sicer posodobitev učnih načrtov, posodobitev načrtovanja in izvajanja kurikula ter podporo in pomoč šolam pri vpeljevanju sprememb (Rupnik Vec in Rupar 2014).

V letu 2008 je bila narejena posodobitev učnih načrtov po celotni vertikali od osnovne šole do gimnazije. Sledila je ugotovitvam domačih in mednarodnih raziskav glede spremljave pouka in šolske prakse.

Glavna načela posodabljanja kurikula se $\mathrm{v}$ učnih načrtih kažejo skozi naslednje cilje (Žakelj 2010):

- posodobitev ciljev in vsebine na ravni znanj matičnih strok,

- posodobitev didaktičnih pristopov učenja in poučevanja,

- procesno-razvojno načrtovanje, v katerega je vključeno načrtovanje dejavnosti učencev v skladu s cilji procesa in pričakovanimi rezultati,

- razvoj celostnih pristopov učenja in poučevanja,

- povečanje kakovosti znanja v smislu trajnosti in uporabnosti,

- spremljava dosežkov in rezultatov,

- jasna opredelitev namena poučevanja predmeta z vidika nadaljnjega izobraževanja in funkcionalnih znanj posameznika,

- omogočanje fleksibilnosti učnega procesa prek izbirnosti in ciljev znotraj predmeta,

- vključevanje medpredmetnih tem in kompetenc $\mathrm{v}$ učne načrte ter

- spodbujanje razvoja sodobnih oblik in metod pouka.

Med splošnimi cilji posodabljanja programov, ki se pojavljajo v vseh razvitih šolskih sistemih, so predvsem preusmeritev od poučevanja $\mathrm{k}$

${ }^{4}$ Konzorcij splošnih gimnazij je vodila Gimnazija Ptuj, Konzorcij strokovnih gimnazij pa Elektrotehniško-računalniška strokovna šola in gimnazija iz Ljubljane. 
učenju (Barr in Tagg 1995), poudarek na uporabi sodobne IKT, usposobljenost za delo $\mathrm{z}$ učenci različnih sposobnosti, nujnost sodelovanja z drugimi učitelji in starši ter raziskovanje, refleksija in evalvacija lastnega dela (Žakelj 2010). Čeprav je pridobivanje specifičnih znanj pri šolskem učenju pomembno, je uporaba znanja odvisna tudi od pridobitve širših znanj, veščin in spretnosti, kot so obvladovanje IKT, skrb za osebe s posebnimi potrebami, integracija, diferenciacija, oblikovanje multikulturnega okolja in medpredmetno povezovanje.

Skladno s prenovo učnih načrtov je potekala tudi didaktična prenova, usmerjena k novim pristopom dela učitelja in učencev. Splošne cilje didaktične prenove navajamo spodaj (Rupnik Vec in Rupar 2006).

- Učitelj pri svojem pouku za učenca ugotavlja in zagotavlja kakovost učne priložnosti. Na takšen način se $z$ učnimi priložnostmi, ki jih učitelj ustvari v razredu, učenec vsestransko razvija in osebnostno raste, razvija kompleksno in kritično mišljenje, razvija raznovrstne kompetence, kot so sporazumevalna, podjetniška in matematična kompetenca, kompetenca uporabe informacijskih tehnologij idr.

- Učitelj se profesionalno razvija in raste, saj ozavešča prepričanja in stališča, ki uravnavajo njegovo ravnanje, identificira podobnosti in razlike, šibkosti in pomanjkljivosti, raziskuje nove možnosti razmišljanja, doživljanja in ravnanja.

- Šolski kolektiv postaja učeča se skupnost. Senge (2012) učečo se šolo opredeli kot organizacijo, za katero so značilni osebna odličnost in jasna osebna vizija zaposlenih, skupna vizija, ozaveščeni mentalni modeli in percepcije, ki uravnavajo dejavnost posameznika, timsko učenje in sistemsko mišljenje oziroma razumevanje in vpogled $\mathrm{v}$ medsebojno soodvisnost vseh elementov sistema.

M I Z Š je v letu 2009 povabilo vse gimnazije k pripravi novih modelov, ki se bodo preverjali s poskusom. ${ }^{5}$ Vsa uvajanja novosti oziroma pilotiranje sprememb v šolstvu namreč poteka preko t.i. poskusov.

V letu 2010 je ZRSŠ izvedel poskus, v katerega je bilo vključenih 18 gimnazij. ${ }^{6} \mathrm{~S}$ poskusom se je želelo ugotoviti:

\footnotetext{
${ }^{5}$ Glej http://www.zrss.si/poskus-v-gimnaziji/?lnk=izhodisca.

${ }^{6} \mathrm{~V}$ poskus vključene gimnazije so bile: Šolski center Srečka Kosovela Sežana, Gimnazija Kranj, Šolski center Nova Gorica (S E T Š), Šolski center Slovenj Gradec, II. gimnazija Maribor, Gimnazija Vič, Gimnazija Nova Gorica, Šolski center Ravne na Koroškem, Gimnazija Ravne, Elektrotehniško-računalniška strokovna šola in gimnazija Ljubljana, Gimnazija Franca Miklošiča Ljutomer, Gimnazija Moste, Ekonomska šola Murska Sobota,
} 
- kako možnost izbire (nivoji zahtevnosti in izbirni predmeti) vpliva na razvoj večje odgovornosti dijakov za lastno znanje,

- učinek različnih izvedb predmetnika in fleksibilne organizacije pouka na znanje,

- učinkovitost organizacije življenja in dela šole ter

- vpliv različnih oblik in načinov usvajanja ter vrednotenja znanja na motivacijo, učno uspešnost in odgovornost za učenje.

V poskus vključene šole so predlagale 18 izvedbenih modelov, ki se lotevajo različnih problematik izvedbe gimnazijskega programa. Nekateri modeli bi zahtevali večje sistemske posege v osnovni standard gimnazijskega izobraževanja, zato so dosegli konsenz, da s poskusom preverijo naslednje elemente:

- izbirnost - preverili so, kako izbira nivojev osnovne in višje ravni zahtevnosti vpliva na doseganje višje širine ter globine znanja,

- fleksibilnost organizacije - preverili so izvedbeno-organizacijske rešitve, ki omogočajo osvajanje trajnejšega in kompleksnejšega znanja,

- obliko in način usvajanja znanja ter njihovo vrednotenje - preverili so načine priznavanja in vrednotenja dejavnosti, ki so del medpredmetnega ali interdisciplinarnega znanja.

V poskus vključene šole so preverile izvajanje vseh treh izbranih elementov in ob koncu predstavile samoevalvacijska poročila (Zavod Republike Slovenije za šolstvo 2014).

Konzorcija splošnih in strokovnih gimnazij sta dejavnosti, določene z izvedbenim načrtom projekta prenove gimnazije, izvajala sočasno. $\mathrm{Na}$ posameznih šolah so uvedli koncept šolskih razvojnih timov, ki so skrbeli za sprotno spremljanje uvajanja posodobitev, predlaganje načinov evalvacije in pripravljanje predlogov za kvalitativne in kvantitativne kazalnike rezultatov. Konzorcij strokovnih gimnazij je zasledoval zlasti dva cilja:

- uvedbo posodobljenih učnih načrtov splošno-izobraževalnih in strokovnih predmetov - uvajanje posodobitev so opravljali s pomočjo šolskih razvojnih timov;

Gimnazija Šiška, Gimnazija Ledina, Gimnazija Ptuj, Gimnazija in srednja šola Kočevje, Srednja vzgojiteljska šola in gimnazija Ljubljana, Gimnazija in ekonomska srednja šola Trbovlje. 
- posodobitev načrtovanja in izvajanja kurikulov strokovnih gimnazij s pomočjo šolskih razvojnih projektov, ki so vključevali razvoj posameznih ključnih kompetenc.

Vse strokovne gimnazije, ki so sodelovale v projektu, so si vsako šolsko leto zastavile razvojne prioritete, med katerimi je bila vsako leto tudi krepitev digitalne pismenosti dijakov. Strategije za uresničitev teh ciljev so vključevale aktivne oblike in metode poučevanja ter učenja ob rabi IKT.

Konzorcij splošnih gimnazij je kot usmeritev projekta izpostavil usmerjenost na dijake, sistematičen strokovni razvoj učiteljev in avtoreguliranost šol. Na ta način so lahko sledili ciljem večje fleksibilnosti organizacije učnega procesa, sodelovalnega in timskega poučevanja ter intenzivnejšega in funkcionalnejšega vključevanja I K T v izobraževalni program.

Ob zaključku projekta posodobitve gimnazijskih programov je konzorcij splošnih gimnazij anketiral učitelje in izdal zaključno poročilo (Bratuša in Kostanjevec 2014), v katerem so objavljene tudi analize uporabe I K T pri poučevanju. V okviru projekta je kar $78 \%$ vključenih šol povečalo rabo I K T pri poučevanju, $66 \%$ jih je ob tem povečalo raznolikost vključevanja IK T v pouk, $46 \%$ pa se je dela na področju I K T lotilo sistematičneje. Zanimivi so tudi rezultati o pogostosti rabe IKT, kjer kar $42 \%$ šol I K T v učni proces vključuje pri vseh predmetih, $41 \%$ pri večini predmetov, $7 \%$ pri polovici in $7 \%$ pri nekaj predmetih. $V$ smislu spodbujanja rabe IK T pri poučevanju so razveseljivi rezultati analize, kjer so raziskovali, ali se je obseg vključenosti rabe I K T v času projekta kaj povečal. Kar $59 \%$ šol meni, da se je obseg rabe precej povečal, $32 \%$ pa, da se je zelo povečal. Kot najpogostejša dejavnost pri rabi I K T je z $68 \%$ raba računalnika pri pouku in $\mathrm{s} 16 \%$ uporaba računalniških programov (modeliranje, preglednice, spletni mediji, e-učbeniki in e-gradiva, sodelovanje). Najpogosteje omenjena težava ob vključevanju I KT je dvom o smiselnosti oziroma pretirani rabe (68\%), $43 \%$ težavo vidi v nepripravljenosti učiteljev za rabo I K T, 37\% pa v neustrezni usposobljenosti učiteljev.

\subsection{Digitalna pismenost v prenovljenih programih}

Večina prenovljenih učnih načrtov $\mathrm{v}$ programu gimnazije je bila sprejeta $v$ letu 2008 in se je $v$ izobraževalnih programih začela uporabljati $v$ šolskem letu 2008/2009. 
Vsi prenovljeni programi spodbujanja digitalne pismenosti dijakov vodijo skozi raziskovanje podatkovnih in informacijskih baz, iskanje, izbiranje, obdelavo, analizo in kritično vrednotenje pridobljenih informacij. I K T se uporablja tudi pri urejanju besedil, izdelavi predstavitev in osnovnih obdelavah podatkov s pomočjo preglednic. Skupna značilnost vseh umestitev spodbujanja digitalne pismenosti v prenovljene učne načrte je videnje I K T kot orodja, $s$ katerim si lahko dijaki pomagajo pri opravljanju šolskih obveznosti. V manjši meri pa je bila raba I K T vključena pri uporabi spremenjenih metod dela.

V nadaljevanju, poleg že omenjenih aktivnosti, ki so skupne vsem prenovljenim gimnazijskim programom, podajamo pregled nekaterih posodobljenih učnih načrtov ${ }^{7}$ posameznih predmetov in načinev vključevanja rabe I K T oziroma spodbujanja digitalne kompetence.

\section{Naravoslovno-tehniški predmeti}

Osrednji predmet, povezan $\mathrm{z}$ rabo I K T v programih obeh vrst gimnazij (splošna in strokovna), je informatika, ki je v predmetnik kot obvezni predmet umeščena le $\mathrm{v}$ 1. letniku. Predmet obsega 70 pedagoških ur. $\mathrm{V}$ višjih letnikih je informatika lahko umeščena kot izbirni predmet, ki lahko ure črpa iz zaloge nerazporejenih ur. Teh je v 2. in 3. letniku po 3 ure na teden, v četrtem pa 11 ur na teden. Število ur informatike je tako po slovenskih gimnazijah različno, saj jih večina izvede le $70 \mathrm{v} 1$. letniku. Maksimalno število ur informatike v gimnazijskih programih je lahko 70 ur v prvih treh letnikih in 105 ali 140 ur v 4. letniku, če se dijak odloči za predmet informatika kot maturitetni predmet (Krapež idr. 2001).

Učni načrti informatike $\mathrm{v}$ 1. letniku predvidevajo naslednje vsebine:

- osnovne pojme informatike,

- razvoj, zgradbo in delovanje računalnika,

- področja rabe in vrste podatkov,

- projektno nalogo ob uporabi dela z datotekami, oblikovanje besedil in slik, izdelavo tabel in grafikonov, iskanje podatkov po svetovnem spletu in izdelavo učinkovite predstavitve.

$\mathrm{V}$ 2. letniku, v okviru izbirnega predmeta, dijaki spoznajo računalniška omrežja in predstavitve, poglobijo znanje o obdelavi slik, avdio- in

${ }^{7}$ Glej http://eportal.mss.edus.si/msswww/programi2013/programi/gimnazija/ucni _nacrti.htm. 
videodatotekah ter spoznajo različne spletne storitve. Poudarek predmeta je predvsem na sodelovalnem delu s pomočjo I K T. V 3. letniku, prav tako v okviru izbirnega premeta, dijaki pridobijo znanja s področja baz podatkov, ekspertnih sistemov, spoznajo pa tudi osnove programiranja. 4. letnik je namenjen poglabljanju znanja in izdelavi obsežnejše maturitetne naloge, zamišljene kot medšolski ali mednarodni projekt. Dijaki izdelajo celovito rešitev, poročilo o izvajanju projekta in opravijo zaključno predstavitev projekta. Informatika je predmet, pri katerem dijaki spoznavajo osnovne zakonitosti informatike ter razvijejo veščine iskanja, zbiranja, hranjenja, vrednotenja, obdelave in uporabe podatkov $\mathrm{z}$ digitalno tehnologijo. Cilj predmeta je razdeljen na dve ravni:

- doseganje splošnih znanj, ki so potrebna za učinkovito uporabo digitalne tehnologije pri razvijanju lastnega znanja in za njegovo predstavitev oziroma posredovanje drugim,

- doseganje posebnih znanj, s katerimi dijaki znanje, veščine in spretnosti nadgradijo, poglobijo in razširijo $\mathrm{v}$ digitalno kompetenco uspešnega ter učinkovitega reševanja informacijskih problemov.

Predmet informatika vključuje znanja, primerna za medpredmetna povezovanja $\mathrm{z}$ vsemi ostalimi gimnazijskimi predmeti. Tako na primer pri fiziki v učnem načrtu poudarjajo, da pri pouku uporabljajo veliko naprav, ki temeljijo na digitalni tehnologiji, predvsem pri meritvah, krmiljenjih, simulacijah pojavov $z$ interaktivnimi računalniškimi animacijami, merjenji s senzorji in $\mathrm{z}$ vmesniki.

Učni načrt predmeta kemija poudari, da vidijo prednostno uporabo IKT pri eksperimentalnem delu, računalniških vmesnikih in senzorjih Vernier, kamerah Flex ter pri predvajanju posnetkov iz različnih virov.

Pri predmetu matematika je $\mathrm{v}$ učnem načrtu že med splošnimi cilji predmeta zapisano, da dijaki spoznavajo in uporabljajo različne I K T kot pomoč za učinkovitejše učenje ter reševanje problemov. IK T se lahko uporablja kot sredstvo za razvoj matematičnih pojmov, za ustvarjanje, simuliranje in modeliranje realnih ter učnih situacij, kot učni pripomoček, metoda dela ali komunikacijsko sredstvo. Dijaki pri svojem delu uporabljajo različno strojno in specializirano programsko opremo ter egradiva; za šolske potrebe iščejo tudi podatke in informacije na spletu.

V učnem načrtu predmeta biologija vključujejo sodobno I K T v svoje delo pri opazovanju, merjenju, shranjevanju podatkov v podatkovnih zbirkah, simulacijah poskusov in modelov, animaciji in dinamičnosti živih sistemov. 
Pri predmetu elektronika digitalno kompetenco vključujejo s spodbujanjem dijakov $\mathrm{k}$ računanju, modeliranju in načrtovanju elektronskih vezij ter naprav in $\mathrm{z}$ animacijami izdelave, uporabe ter delovanja elektronskih naprav.

\section{Družboslovno-humanistični predmeti}

Pri predmetu geografija vidijo spodbujanje digitalne pismenosti prek rabe Geografskega informacijskega sistema (GIS) in drugih orodij (G P S in Google Earth), s katerimi zbirajo, obdelujejo in prikazujejo podatke o prostorskih pojavih ter procesih.

Predmet likovna umetnost $\mathrm{v}$ učnem načrtu rabo I K T predvideva le pri medpredmetnih povezavah $\mathrm{v}$ obliki dela s slikami, fotografijami, $\mathrm{z}$ digitalnimi video posnetki, animacijami, pri oblikovanju vseh vrst in tridimenzionalnem modeliranju.

V učnem načrtu predmeta psihologija je poudarjeno, da učitelj razvoj digitalne in informacijske pismenosti omogoča s spodbujanjem raziskovanja podatkovnih baz ter virov v namene poglabljanja lastnega znanja. Pri obdelavah podatkov dijaki uporabljajo preglednice in programsko opremo za obdelavo statističnih podatkov.

Pri predmetu podjetništvo je $\mathrm{v}$ učnem načrtu uporaba IK T zapisana pri raziskavah trga, oblikovanju poslovnega načrta, predstavitvah ipd.

Učni načrt predmeta športna vzgoja predvideva spodbujanje razvoja digitalne kompetence pri rabi sodobnih tehnoloških pripomočkov, $\mathrm{s}$ katerimi dijak zbira, obdeluje, razlaga in vrednoti osebne dosežke (uporaba merilcev srčne frekvence, računalniških programov, svetovnega spleta, športno-vzgojnega kartona idr.) ter pri tem uporablja merski inštrumentarij, ki temelji na razumevanju osnovnih matematičnih funkcij, kot je uporaba grafikonov in statistik.

Razvoj digitalne pismenosti je $\mathrm{v}$ učni načrt predmeta zgodovina vključen $v$ povezavi $z$ iskanjem zgodovinskih virov na svetovnem spletu ter kot orodje za komunikacijo prek e-pošte, spletnih forumov in konferenc, $v$ povezavi z uporabo spletnih učilnic in kot pripomoček pri izdelavi mape dosežkov oziroma listovnika.

Učni načrt predmeta glasba uporabo I K T predvideva pri iskanju informacij o glasbi na svetovnem spletu ter ustvarjanju, snemanju in predvajanju glasbe.

\section{Jeziki}

Pri predmetu slovenščina razvoj posameznikove digitalne kompetence vidijo pri razvijanju sporazumevalne zmožnosti s pomočjo IK T. Dijaki 
samostojno uporabljajo primerne didaktične računalniške programe in svetovni splet kot vir podatkov ter komunikacijsko orodje.

$\mathrm{V}$ učnem načrtu predmeta angleščina je razvoj digitalne kompetence opredeljen $\mathrm{z}$ uporabo specializirane programske opreme in rabo e-gradiv za angleščino.

Pri predmetu francoščina dijaki digitalno kompetenco razvijajo pri vključevanju v nacionalne ali mednarodne mrežne projekte.

Učni načrt predmeta latinščina uporabo I K T predvideva pri iskanju informacij na svetovnem spletu ali uporabi programske opreme, kot je npr. slovar.

Pri predmetu nemščina je $\mathrm{v}$ učnem načrtu zapisana uporaba spletnih iskalnikov in slovarjev, raba elektronskih gradiv in spodbujanje komuniciranja v nemškem jeziku $\mathrm{z}$ vključevanjem $\mathrm{v}$ mednarodne mrežne projekte.

\subsection{Vključevanje tehnologije $v$ učenje in poučevanje}

Hitro razvijajoče se tehnologije spreminjajo tudi vlogo učiteljev. Od njih se pričakuje sprejetje in uvajanje novih, z I K T podprtih vsebin in pristopov, podporo pri učenju in ocenjevanju, sodelovanje $z$ drugimi učitelji znotraj in zunaj šole, uporabo digitalnih strategij, vodenje in mentoriranje učečih ter organiziranje lastnega dela $\mathrm{v}$ skladu $\mathrm{z}$ administrativnimi zahtevami. Sodobne izobraževalne reforme od učiteljev pričakujejo spodbujanje učencev pri formalnem in neformalnem učenju ob uporabi I K T, $v$ šoli in doma. V skladu s temi povečanimi pričakovanji se morajo učitelji dodatno strokovno razvijati, ob tem uporabljati različne medije in vire, nove učne scenarije, družbena omrežja in skupaj z učenci graditi učne skupnosti (Johnson idr. 2014).

Uvedba novih tehnologij prinaša bolj k učencu osredotočeno učenje, kar zahteva drugačne strategije dela učitelja. V idealnih razmerah ta postaja bolj mentor, ki obiskuje in svetuje posameznim skupinam učencev, jih vodi in usmerja in jih hkrati prepušča lastnemu učenju. Ta trend poskušajo v E U spodbujati s projekti, kjer se predstavljajo primeri dobrih praks. Za učitelja 21. stoletja pa nastajajo tudi novi viri. Primer takega projekta je eTwinning ${ }^{8}$, spletna skupnost in sodelovalni prostor šol, kjer učenci osnovnih in srednjih šol sodelujejo in izmenjujejo ideje o uporabi I K T ter socialnih medijev. Te aktivnosti pomenijo dodatne napore za učitelje, katerih naloga ni le razumeti, kaj omogočajo sodobna orodja, temveč jih tudi smiselno vključevati v svoje poučevanje. Večja dosto-

\footnotetext{
${ }^{8}$ Glej http://www2.cmepius.si/etwinning.aspx.
} 
pnost informacij na internetu spreminja tudi paradigmo o učitelju kot primarnem viru informacij in znanja, saj je le-to zdaj dosegljivo hitro in ob vsakem času. Naloga učitelja je tako spodbujanje radovednosti učencev za samostojno in vseživljenjsko učenje ob rabi sodobnih tehnologij (Bellanca in Brandt 2010).

Intenzivno vključevanje rabe I K $\mathrm{T} \mathrm{v}$ šole in poučevanje učiteljev temelji na spoznanjih, da I K T in internet krepita učne izkušnje otrok ter mladostnikov in delujeta kot spodbujevalec širših sprememb v načinu učenja. I K T je prisotna tudi v vsakdanjem življenju posameznika, v službi in v prostem času, vsak dan pa se pojavljajo tudi nove storitve in zahteve po znanjih, ki zahtevajo digitalno pismenega uporabnika. Ob uporabi ustreznih tehnologij se poučevanje pomika tudi izven prostorov šole, pri čemer se zmanjšuje prepad med bogatimi in revnimi ter drugimi izključenimi skupinami. I K T, nenazadnje, omogoča tudi zmanjševanje stroškov administrativnega poslovanja šol (O E C D 2015).

\subsection{IK T in učenje - rezultati raziskave PIS A 2012}

Mednarodna raziskava PISA (Programme for International Student Assessment $)^{9}$ je raziskava, katere cilj je oceniti izobraževalne sisteme vključenih držav preko testiranja pridobljenih veščin in znanj 15-letnih učencev v branju, matematiki ter znanosti. $\mathrm{V}$ zadnji izvedeni raziskavi leta 2012 je sodelovalo 510.000 učencev iz 65 držav, med katerimi je bila tudi Slovenija.

V mednarodni raziskavi PIS A 2012 so preučevali pogostost uporabe računalnika v šoli ob spremljanju devetih aktivnosti, ki so:

- spletno klepetanje,

- uporaba e-pošte,

- brskanje po spletu s ciljem iskanja informacij,

- prenašanje, nalaganje in brskanje med e-gradivi na šolski spletni strani,

- objavljanje rezultatov dela na šolski spletni strani,

- igranje simulacij,

- vadba in ponavljanje osvojenega znanja (npr. pri matematiki ali učenju tujega jezika),

- izdelava domače naloge s pomočjo računalnika,

- skupinsko delo in komuniciranje z ostalimi člani skupine.

${ }^{9}$ Glej http://www.oecd.org/pisa/keyfindings/pisa-2012-results.htm. 
Med članicami OECD ${ }^{10}$ v povprečju $72 \%$ učečih v šoli uporablja namizni, prenosni ali tablični računalnik ( $93 \%$ vprašanih računalnik uporablja doma). Najpogostejša aktivnost, ki jo izvajajo v šoli, je brskanje in iskanje informacij na spletu ( $42 \%)$. Učeči to počnejo enkrat ali večkrat tedensko. Najmanj pogosta aktivnost je igranje simulacij, ki jo v povprečju izvaja le $11 \%$ vprašanih. Največje razlike je opaziti pri uporabi računalnika za spletni klepet, kajti leta 2012 je to aktivnost v povprečju izvajalo 18,5\% učencev (2009 14,6\%), in pri uporabi računalnika za opravljanje domačih nalog (21,7\% leta 2012 v primerjavi z 17,9\% leta 2009). Če združimo vseh 9 aktivnosti v enoten kazalnik »Uporaba I K T v šoli«, lahko sklepamo, da so med letoma 2009 in 2012 najbolj napredovale države Avstralija, Danska, Nizozemska in Norveška, medtem ko so nazadovale Japonska, Koreja in Šanghaj (O E CD 2016).

Pomemben kazalnik je tudi uporaba interneta pri delu $\mathrm{v}$ šoli. $\mathrm{V}$ povprečju držav OECD vsak učenec internet uporablja 25 minut na dan. Države z najvišjim kazalnikom uporabe I K T v šoli imajo precej višje rezultate (Avstralija 58 minut, Danska 46 minut in Grčija 42 minut). V Sloveniji učenci internet $v$ šoli uporabljajo $v$ povprečju 28 minut na dan. Zanimiv je podatek, da v 11 državah, med katerimi so tudi razvita gospodarstva, kot so Nemčija, Italija ali Japonska, večina učečih v običajnem šolskem dnevu ne uporablja interneta (povprečje OECD je $36 \%$ ).

V raziskavi PIS A 2012 so preučili tudi pogostost rabe računalnika pri poučevanju matematike. Sestavili so seznam 7 tipičnih nalog in učence vprašali, ali so $\mathrm{v}$ mesecu pred reševanjem vprašalnika sami ali pa z učitelji uporabili katero izmed ponujenih možnosti uporabe I KT. Med tipične naloge so vključili vnašanje podatkov v preglednice, risanje grafikonov, izračune, konstruiranje geometrijskih teles, reševanje enačb, risanje histograma, spreminjanje in opazovanje grafa funkcije ob spreminjanju parametrov. $V$ povprečju držav $O E C D$ je manjšina vprašanih (14\%) potrdila uporabo vsaj ene izmed ponujenih nalog s strani učitelja, medtem ko je $32 \%$ učečih samih opravilo vsaj eno nalogo. Večje razlike se pojavijo med posameznimi državami. Več kot dve tretjini vprašanih je potrdilo uporabo ene izmed nalog s strani učitelja na Norveškem (82\%), v Jordaniji (80\%) in na Danskem (71\%). Slovenija (42\%) je tudi $\mathrm{v}$ tem primeru blizu povprečja držav O E C D (46\%). Povprečno najpogosteje opravljeni nalogi v preučevanih državah sta bili uporaba preglednic $(19 \%)$ in risanje grafikonov (16\%).

\footnotetext{
${ }^{10}$ Glej http://www.oecd.org/pisa/aboutpisa/pisa-2012-participants.htm.
} 
Pri kazalniku uporaba računalnika za opravljanje domačih nalog so izhajali iz dejstva, da tehnologija omogoča razširitev učnega dneva tudi izven fizične lokacije šole. Učne aktivnosti se lahko izvajajo prek spleta ali z uporabo programske opreme. V raziskavi P IS A 2012 so učeče vprašali o pogostosti opravljanja 7 nalog. V povprečju držav O E CD tako $48 \%$ učečih opravi domačo nalogo s pomočjo računalnika, $38 \%$ jih uporablja e-pošto za komuniciranje s sošolci, 33 \% jih s sošolci deli e-gradiva, $30 \%$ jih preverja obvestila na šolski spletni strani in le $21 \%$ jih komunicira $\mathrm{z}$ učiteljem ali na takšen način oddaja domače naloge. Na ravni posameznih držav so najvišje uvrščene Danska, Estonija, Nizozemska in Urugvaj. Med posameznimi nalogami lahko, v primerjavi z letom 2009, največjo razliko opazimo pri preverjanju obvestil na spletnih straneh šole ( $+9,6$ odstotne točke), brskanju po internetu za informacijami ( 9,5 odstotne točke) in prenosu ter nalaganju e-gradiv s šolske spletne strani (+ 7,3 odstotne točke). Pri opravljanju domače naloge s pomočjo računalnika pa je prišlo do nazadovanja za 2,1 odstotne točke, kar je presenetljivo. Slovenija se je pri kazalniku uporabe I K T izven šole za potrebe opravljanja domačih nalog uvrstila na visoko 5. mesto, kar lahko povežemo $\mathrm{z}$ izvajanjem projektov izobraževanja učiteljev za rabo spletnih učilnic.

Raziskava PIS A 2012 je pokazala precej velike razlike med preučevanimi državami. Vzrok nizke rabe I K T pri učenju in poučevanju je pri nekaterih državah lahko v pomanjkljivi infrastrukturi, nevlaganju v I K T ali pa v pomanjkanju sredstev za večje vključevanje tehnologije. Seveda je vzrok lahko tudi v nepripravljenosti posameznih šol ali učiteljev za vključevanje IKT v njihovo poučevanje. Po drugi strani pa zgolj vzpostavitev infrastrukture in nakup strojne opreme ni dovolj, potrebno je zagotoviti tudi ustrezna e-gradiva in programsko opremo, kar pa je že povezano z izobraževalno politiko posamezne države. Učiteljem je treba omogočiti prilagoditev učnih načrtov in nadaljnje strokovno izpopolnjevanje za rabo IK T pri poučevanju (Tondeur idr. 2012).

Kazalnik, pri katerem je Slovenija dosegla najslabši rezultat, je dostopnost računalnika v šoli. Na ravni držav OECD je, v povprečju, dostopnost namiznega, prenosnega in/ali tabličnega računalnika 92odstotna, kar v primerjavi z letom 2009 pomeni padec $\mathrm{v}$ višini o,6 odstotne točke. V Sloveniji je, v enakem primerjanem obdobju, dostopnost računalnika v šoli padla za 9 odstotnih točk, nato pa sledi skupina držav (Belgija, Japonska in Koreja), kjer je dostopnost padla za 5 odstotnih točk. 
Na ravni držav O E C D, v povprečju, en računalnik v šoli uporablja med 4 in 5 učencev. Ta kazalnik je narasel $v 17$ preučevanih državah, padel pa v 6. Istočasno se je znižalo število šol, ki niso priključene na internet, $s$ 4 na $3 \%$. Zanimiva je tudi sprememba v strukturi naprav, ki jih v šolah uporabljajo za dostopanje do interneta. Še vedno se najpogosteje uporabljajo namizni računalniki, čeprav se je njihovo število v preučevanem obdobju 2009-2012 zmanjšalo za 3 odstotne točke, obenem pa je za 8 odstotnih točk naraslo število prenosnih računalnikov. Uporabo prenosnih naprav še posebej spodbujajo na Danskem, kar se kaže v visokem deležu uporabe ( $91 \%$ ) prenosnih naprav, drugod pa v malo nižjem: Avstraliji (89\%), Norveški (87\%) in Švedski (75\%). Z uporabo prenosnih naprav uporaba IK T pri pouku ni več omejena le na računalniške učilnice, temveč se s primerno infrastrukturo v šoli I K T lahko uporablja v katerikoli učilnici. Opazen je tudi pojav e-bralnikov, predvsem v Jordaniji (39\%), Grčiji (37\%) in Srbiji (23\%). Ob večanju uporabe mobilnih naprav velja omeniti tudi večji delež izvajanja z IK T povezanih nalog $\mathrm{v}$ primerjavi $\mathrm{z}$ uporabniki namiznih računalnikov. Prenos, nalaganje in brskanje po šolskih digitalnih virih $27 \%$ učencev opravlja s prenosnimi napravami in $18 \% \mathrm{z}$ namiznimi računalniki.

Raziskava je vključevala tudi ravnatelje posameznih šol in njihovo podporo ter vključenost rabe I K $\mathrm{T}$ v šolskih pravilnikih. Raziskovalce je zanimalo, ali v šoli obstajajo navodila oziroma pravilnik o načinih rabe računalnika pri pouku matematike (kateri računalniki in vrsta programske opreme). V povprečju držav O E CD $32 \%$ učencev obiskuje šole, kjer so ravnatelji potrdili obstoj takih pravilnikov, so pa velike razlike med posameznimi državami. Slovenija je povsem pri vrhu s $93 \%$ učencev, na dnu pa je Švedska s $5 \%$.

\subsection{Informatizacija slovenskih šol in projekt Računalniško opismenjevanje}

V Sloveniji je uporaba IKT del učnih načrtov posameznih predmetov ali pa se poučuje v posameznem, ločenem predmetu $\mathrm{v}$ osnovni in srednji šoli. Kot navaja Brečko (2009), se je proces uvajanja I K T v šole začel leta 1972 s projektom računalniške pismenosti, v katerem je sodelovalo 30 šol. V okviru projekta so se izvajala izobraževanja učiteljev, pripravili pa so se tudi učbeniki za učitelje in učence. Na podlagi rezultatov evalvacije tega projekta so leta $1976 \mathrm{v}$ kurikul srednjih šol uvedli predmet računalništvo. V letu 1983 so, kot del iniciative za standardizacijo računalniške strojne in programske opreme, $v$ srednje šole vpeljali raču- 
nalnike Spectrum in Commodore 64. Sledili so projekti Logo (uporaba lastne različice programskega jezika logo, 1987), projekt RAČE K (RAČEK - RAČ unalniška E Ksplozija, 1988) in projekt Petra (1992), s katerim so začeli proces informatizacije petega razreda osnovne šole pri predmetih slovenščina, likovna in tehnična vzgoja. V projekt Petra je bilo vključenih 175 osnovnih šol. Z njim so se začele uvajati nove oblike poučevanja, kot so timsko poučevanje in sodelovalno učenje, hkrati pa se je fokus uporabe IKT prvič premaknil na didaktično področje poučevanja $\mathrm{z}$ računalniki. Ta je zahteval sistematičnejše poučevanje učiteljev, zato je ZRSŠ leta 1993 začel s projektom Učitelji inštruktorji. Cilj projekta je bil izobraževanje in usposabljanje učiteljev za uporabo novosti na področju programske opreme in izmenjava izkušenj (Krapež idr. 2001).

V letu 1994 se je v okviru Šolskega tolarja začel šestletni program Računalniško opismenjevanje (RO), ${ }^{11}$, katerega namen je bil dvigniti raven informatizacije šolstva. Cilji programa so bili:

- opremiti šole z IKT,

- pripraviti usposabljanja za učitelje in učence za uporabo IKT,

- poenotiti programsko opremo za poučevanje, administracijo in upravljanje,

- omogočiti raziskovalno in razvojno delo na področju vključevanja novih tehnologij in

- standardizirati računalniško podprte prenose podatkov med šolami in drugimi institucijami.

Brečko, Vehovar in Dolničar (2008) izpostavljajo, da je bil namen projekta RO oblikovanje možnosti za informatizacijo organizacije poučevanja in tudi samega poučevanja. Uporaba računalnikov $v$ šolah naj bi podpirala tako osnovne izobraževalne cilje kot tudi integracijo učnih načrtov. Računalniško opismenjevanje je bilo usmerjeno v vse ravni izobraževanja. Pripravljena so bila številna izobraževanja in usposabljanja učiteljev. V program se je vključilo 16.500 vzgojiteljev in učiteljev.

Aktivnosti programa RO so bile razdeljene na naslednja področja:

- osnovno usposabljanje,

- didaktično-metodološko usposabljanje za učitelje, ki uporabljajo računalnike pri svojih učnih urah,

${ }^{11}$ Glej https://goo.gl/4s3vEi. 
- specializirani seminarji za koordinatorje informacijskih sistemov in

- izobraževanja za projekte, posebne programe in skupine.

Nadaljevanje projekta računalniškega opismenjevanja je leta 1999, pod vodstvom ZRSš, potekalo v okviru novega projekta Informatizacija predmetov, ki je bil sestavljen iz naslednjih sklopov:

- Pika - informatizacija učno-vzgojnih dejavnosti v vrtcih in nižjih razredih osnovne šole,

- Timko - spodbujanje sodelovalnega in timskega dela z IKT pri učencih od 5. do 9. razreda osnovne šole, dijakih gimnazijskih in srednješolskih strokovnih programov,

- Vesna, ki je bil namenjen iskanju novih idej, predlogov in pobud za razvoj informatizacije v vrtcih, osnovnih in srednjih šolah.

\subsection{E-kompetentna šola - projekt E-šolstvo}

Ministrstvo za šolstvo in šport je $z$ namenom spodbujanja vključevanja I K T V poučevanje in učenje $\mathrm{v}$ letu 2008 razpisalo projekte, katerih cilji so bili nadgradnja obstoječih dejavnosti na področjih usposabljanja učiteljev in drugih strokovnih delavcev ter svetovanje, didaktična podpora in tehnična pomoč vzgojno-izobraževalnim zavodom. Izbrani partnerji so projekt poimenovali E-šolstvo (Gruden idr. 2013). Cilj projekta je bila e-kompetentna šola, kjer učitelji in učenci pri svojem delu ob rabi I K T spreminjajo izobraževalne procese, uporabljajo e-gradiva in se povezujejo $\mathrm{z}$ drugimi zavodi.

E-kompetentna šola se izraža $z$ naslednjimi zmožnostmi (Kreuh in Brečko 2011):

- e-kompetentno vodenje šole,

- e-kompetentni učitelji,

- e-kompetentni računalnikar, organizator informacijskih dejavnosti na šoli.

Na področju izobraževanja so v okviru projekta E-šolstvo izoblikovali okvir e-kompetentnega učitelja, ki je pridobil naslednje kompetence (Kreuh in Brečko 2011):

- poznavanje in zmožnost kritične uporabe IKT,

- zmožnost komuniciranja in sodelovanja na daljavo (učitelj, vzgojitelj, drugi delavci v viz, starši, učenci), 
- zmožnost iskanja, zbiranja, obdelave, vrednotenja (kritične presoje) podatkov, informacij in konceptov,

- varna raba in upoštevanje pravnih ter etičnih načel uporabe in objave informacij,

- izdelava, ustvarjanje, posodabljanje, objava izdelkov (gradiv),

- zmožnost načrtovanja, izvedbe, evalvacije pouka (učenja in poučevanja) $\mathrm{z}$ uporabo I K T.

Vzgojno-izobraževalni zavodi, ki so se vključili v projekt E-šolstvo, so pridobili (Kreuh idr. 2012):

- možnost stalnega in brezplačnega usposabljanja prek seminarjev ter svetovanj s področja rabe I K T,

- svetovalca vodstvu šole, ki jim je pomagal, jih motiviral in usmerjal na poti do e-kompetentnosti,

- možnost oblikovanja e-šolskega razvojnega tima,

- pripravo vizije in operativnega načrta informatizacije šole,

- stalno spremljavo in evalvacijo, ki omogoča vključevanje potreb neposredno iz prakse,

- uvajanje novih postopkov poučevanja, učenja in vodenja šole s pomočjo IKT.

Posebno in pomembno vlogo na poti šole do e-kompetentnosti je imel ravnatelj, zato so za področje vodenja šole pripravili posebna izobraževanja in svetovanja. Med naloge ravnatelja je sodilo (prav tam):

- spremljanje informacij o projektu E-šolstvo,

- vzpodbujanje zaposlenih za vključevanje v projekt,

- sodelovanje s šolskim razvojnim timom pri pripravi načrta informatizacije šole,

- vključevanje načrtovanih aktivnosti, povezanih z uporabo IK T, v letni delovni načrt šole,

- sledenje cilju e-kompetentnega vodenja.

Ravnateljeva pot do e-kompetentnosti je bila sestavljena iz štirih modulov (preglednica 4.1), s katerimi je ravnatelj lahko pridobil vseh 6 kompetenc.

Računalnikar oziroma koordinator I K T je s pridobljenimi znanji $\mathrm{v}$ šoli sodeloval $\mathrm{z}$ učitelji pri načrtovanju pouka ob rabi $\mathrm{I} \mathrm{K} \mathrm{T}$ in $\mathrm{z}$ ravnateljem pri načrtovanju dela $\mathrm{v}$ šoli ter pri uvajanju sprememb na poti do e-kompetentne šole. 
Preglednica 4.1 Moduli izobraževanja e-kompetentnega ravnatelja

\begin{tabular}{|c|c|c|c|}
\hline Naziv modula & (1) & (2) & (3) \\
\hline Komunikacija na daljavo v delovnem okolju in širše & 16 & 8 & 488 \\
\hline Ravnateljevo načrtovanje in spremljanje dela z I K T & 16 & 8 & 365 \\
\hline Pravilna in kritična uporaba podatkov in informacij & 16 & 8 & 227 \\
\hline Objava podatkov & 16 & 8 & 66 \\
\hline \multicolumn{4}{|c|}{$\begin{array}{l}\text { O P OM B E Naslovi stolpcev: (1) izobraževanja v živo (ure), (2) izobraževanja na daljavo } \\
\text { (ure), (3) število udeleženih ravnateljev. }\end{array}$} \\
\hline \multicolumn{4}{|c|}{ Preglednica 4.2 Rezultati projekta E-šolstvo (v številkah) } \\
\hline Postavljen cilj & Načrtovano & & Izvedeno \\
\hline Novi in prenovljeni seminarji & 193 & & 215 \\
\hline Udeleženci na izobraževanjih & 33.616 & & 36.574 \\
\hline Udeleženci na izobraževanju sodelavcev & 1.570 & & 4.330 \\
\hline Vključeni viz & 1.570 & & 1.900 \\
\hline Svetovanja v živo & 10.000 & & 14.920 \\
\hline Udeleženci na svetovanjih & 7.000 & & 39.073 \\
\hline
\end{tabular}

Ob koncu projekta E-šolstvo v letu 2013 je vodstvo projekta predstavilo rezultate (E-šolstvo 2013) (preglednica 4.2).

Zaključna evalvacija projekta E-šolstvo je pokazala, da so se učitelji po šolah v času izvajanja projekta v veliki meri $(86 \%)^{12}$ vključevali v oblikovanje šolskega operativnega načrta izvajanja aktivnosti informatizacije, kar kaže na zavedanje o pomenu vseživljenjskega učenja med učitelji in drugimi strokovnimi delavci šole.

${ }^{12}$ Glej http://projekt.sio.si/e-solstvo/. 



\section{Raziskava digitalne pismenosti}

\subsection{Metodologija zbiranja in obdelave podatkov}

Raziskavo o stopnji digitalne pismenosti dijakov gimnazijskih programov smo izvedli v šolah, ki izvajajo splošne in strokovne gimnazijske programe. Anketni vprašalnik smo oblikovali tako, da smo v njem upoštevali preverjanje vseh področij in dimenzij, na katerih temelji okvir digitalne pismenosti D CA, predstavljen v poglavju 3.1. Vprašanja so bila razdeljena $v$ štiri kategorije, pri čemer smo posamezna vprašanja prilagodili posebnostim slovenskega izobraževanja ali pa smo jih posodobili v skladu s trenutnim tehnološkim razvojem.

Prvo različico vprašalnika smo preverili na vzorcu 60 dijakov in študentov Šolskega centra Kranj. Težav z razumevanjem vprašanj ni bilo, vendar je bil vprašalnik glede na povprečni čas reševanja - 47 minut preobsežen, zato smo ga skrajšali in ustrezno prilagodili. Izvedli smo drugo pilotno preverjanje, ki je pokazalo ustrezno jasnosti vprašanj, skrajšal pa se je tudi čas reševanja, in sicer na povprečnih 18 minut.

Anketiranje je potekalo $z$ vprašalnikom (priloga 3), ki smo ga pripravili s spletnim orodjem $1 \mathrm{KA} .{ }^{1}$ Vprašalnik je vseboval 7 vprašanj s področja tehnološke dimenzije, 10 vprašanj s področja kognitivne dimenzije in 13 vprašanj s področja etične dimenzije digitalne pismenosti. Anketiranci so odgovarjali še na 11 splošnih in demografskih vprašanj. Večina vprašanj je bila zaprtega tipa, kar nam je omogočilo natančno obdelavo podatkov.

Vzorec anketiranja je bil namenski, kajti k reševanju smo povabili le dijake prvega in četrtega letnika gimnazijskih programov, saj smo želeli preveriti, kako se digitalne kompetence dijakov spreminjajo med šolanjem na gimnaziji. Dostop do vprašalnika je bil javen, vendar znan le povabljenim šolam. Povabilo k reševanju je bilo $\mathrm{z}$ e-pošto poslano vsem ravnateljem splošnih in strokovnih gimnazij ${ }^{2}$ s prošnjo po vključitvi di-

${ }^{1}$ Glej https://www.1ka.si/a/85987.

${ }^{2} \mathrm{Na}$ osnovi podatkov MIzš je v Sloveniji 64 šol, ki izvajajo programe splošne ali stro- 
5 Raziskava digitalne pismenosti

Preglednica 5.1 Struktura anketirancev po geografskih regijah

\begin{tabular}{lrr}
\hline Regija & $(1)$ & $(2)$ \\
\hline Pomurska & 35 & 7,1 \\
Podravska & 62 & 12,7 \\
Koroška & 0 & 0,0 \\
Savinjska & 0 & 0,0 \\
Zasavska & 1 & 0,2 \\
Posavska & 0 & 0,0 \\
Jugovzhodna & 161 & 32,9 \\
Osrednjeslovenska & 53 & 10,8 \\
Gorenjska & 167 & 34,1 \\
Primorsko-notranjska & 1 & 0,2 \\
Goriška & 11 & 2,0 \\
Obalno-kraška & 0 & 0,0 \\
\hline
\end{tabular}

O P Oм в E Naslovi stolpcev: (1) število dijakov, (2) delež dijakov v odstotkih.

jakov njihove šole v anketiranje. Slednje je bilo anonimno. Za anketiranje mladoletnih, starejših od 15 let, soglasje staršev ni bilo potrebno. ${ }^{3}$

Podatke popolno izpolnjenih anket smo uvozili v program za delo $\mathrm{s}$ preglednicami, kjer smo nekaterim spremenljivkam določili vrednosti, ki so bile osnova za kasnejše izračune. S pomočjo tega programa smo izračunali osnovne vrednosti opisne statistike, oblikovali preglednice ter narisali grafikone. Nato smo podatke izvozili v program za statistično obdelavo (s P S s), kjer smo s pomočjo Spearmanovega testa korelacije in Mann-Whitney U-testa ugotavljali razlike med vzorci in potrjevali v uvodu postavljene hipoteze.

\subsection{Predstavitev vzorca}

Anketiranje je potekalo od 5.3. 2016 do 25.3. 2016. V času izvajanja anketiranja smo pridobili 545 odgovorov, med katerimi je bilo 490 popolnih in zato vključenih $\mathrm{v}$ analizo.

Vprašalnik je izpolnilo $52 \%$ moških. Anketo je popolno izpolnilo več dijakov 1. letnika (65,5\%). Večina (70\%) anketiranih dijakov je obiskovala splošne gimnazijske programe. Anketiranci prihajajo iz različnih regij (preglednica 5.1).

Odziv šol po Sloveniji ni bil enakomeren, zato smo posamezne regije,

kovne gimnazije; glej https://krka1.mss.edus.si/registriweb/ZavodiPodrobno.aspx.

${ }^{3}$ Glej http://www.ip-rs.si. 
Namizni ali prenosni računalnik Mobilni tel. brez dostopa do interneta Mobilni tel. $\mathrm{z}$ dostopom do interneta

Tablični računalnik

Prenosni in tablični rač., mobilni tel.

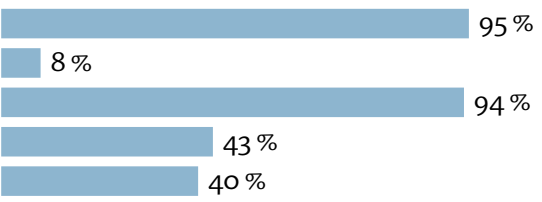

Slika 5.1 Vrste naprav za povezovanje $\mathrm{z}$ internetom

skladno s kohezijsko razdelitvijo Slovenije (Statistični urad Republike Slovenije 2014), razdelili na vzhodno in zahodno Slovenijo.

Vzhodna Slovenija obsega naslednje regije: pomursko, podravsko, koroško, savinjsko, zasavsko, spodnjesavsko, jugovzhodno, notranjskokraško, zahodna pa: osrednjeslovensko, gorenjsko, goriško in obalnokraško.

$\mathrm{Z}$ razdelitvijo na kohezijske regije smo dobili relativno uravnoteženi skupini, ki smo ju lahko kasneje uporabili pri analizi. V raziskavo je bilo tako vključenih $53 \%$ anketirancev iz vzhodne in $47 \%$ iz zahodne kohezijske regije.

V nadaljevanju nas je zanimalo, kakšne naprave dijaki doma uporabljajo za povezovanje z internetom (slika 5.1). Anketiranci so lahko izbrali več možnih odgovorov. Rezultati raziskave so pokazali, da imajo skoraj vsi (95\%) anketiranci doma računalnik ali pametni telefon $\mathrm{z}$ dostopom do interneta (94\%). Tablični računalnik uporablja slaba polovica (43\%) dijakov. Po raziskavi Eurostata ${ }^{4}$ v Sloveniji $94 \%$ posameznikov v starostnem obdobju od 16 do 19 let za dostop do interneta uporablja prenosnik, tablični računalnik ali pametni telefon.

Glede na stanje opremljenosti dijakov s tehnologijo za dostop do interneta, ne preseneča podatek, da $95 \%$ vprašanih do interneta dostopa vsak dan. Po raziskavi Eurostata ${ }^{5}$ je v primeru starostnega obdobja od 16 do 19 let ta vrednost za Slovenijo $90 \%$, medtem ko je povprečje E U-28 nekoliko višje ( $91 \%)$.

Zanimalo nas je, s katerimi napravami najpogosteje dostopajo do interneta. Na osnovi te informacije lahko učitelji pripravijo ustrezna egradiva. Rezultati raziskave kažejo (slika 5.2), da sta najpogostejši napravi, ki ju dijaki uporabljajo za dostop do interneta, pametni telefon $(63 \%)$ in namizni ali prenosni računalnik $(26 \%)$.

\footnotetext{
${ }^{4}$ Glej http://ec.europa.eu/eurostat/statistics-explained/index.php/Information _society_statistics_-_households_and_individuals/sl.

${ }^{5}$ Glej http://ec.europa.eu/eurostat/statistics-explained/index.php/Being_young_in _Europe_today_-_digital_world\#Youth_online:_a_way_of_life.
} 


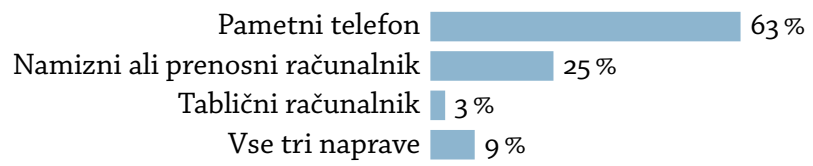

Slika 5.2 Naprave za najpogostejši dostop do interneta

Razvoj infrastrukture in tehnološki razvoj mobilnih naprav v zadnjih letih je močno povečal dostopnost do interneta z mobilnih naprav, kar je priložnost za razvoj učnih e-vsebin, prilagojenih za sodobne pametne telefone. Po podatkih Eurostata iz leta 2012 je v Sloveniji do interneta s pomočjo pametnih telefonov dostopalo $57 \%$ populacije $\mathrm{v}$ starostnem obdobju od 16 do 19 let (povprečje E U-28 je znašalo 53\%, države z najvišjo stopnjo pa so Velika Britanija s $86 \%$, Švedska s $84 \%$ ter Hrvaška, Nizozemska in Norveška s $77 \%$ ).

Glede na predhodne rezultate smo dobili pričakovane odgovore tudi pri vprašanju o dostopanju do interneta od doma. Skoraj vsi dijaki (97\%) od doma do interneta dostopajo vsak dan. Kot zanimivost lahko navedemo, da je le 1 dijak navedel, da doma nima dostopa do interneta. Dijaki do interneta najpogosteje (92\%) dostopajo doma, medtem ko jih le $5 \%$ navaja, da to počno le v šoli. Dijaki na internetu izvajajo različne aktivnosti (preglednica 5.2). Iz nabora ponujenih aktivnost so lahko označili eno ali več aktivnosti.

Anketirani dijaki internet najpogosteje uporabljajo za komunikacijo s prijatelji (89\%). Pri tem uporabljajo različne načine neposrednega sporočanja. E-pošta je manj uporaben način komunikacije, saj prek nje komunicira manjši delež anketirancev ( $55 \%)$. Zelo pogosto iščejo tudi informacije za osebno rabo ali za šolo (81\%). Dijaki, ki so med ponujenimi možnosti označili možnost Drugo, so navedli, da je njihova najpogostejša aktivnost igranje iger.

V nadaljevanju nas je zanimalo, kje so dijaki pridobili svoje znanje $s$ področja I K T (preglednica 5.3). Anketiranci so lahko izbrali le eno možnost, lahko pa so tudi navedli, da znanja s področja I K T še niso pridobili in ga samoocenili kot šibko oziroma nezadovoljivo.

Največ dijakov svoje znanje s področja I K T pridobiva prek virov, ki so dostopni na spletu (52\%), medtem ko je izobraževalni proces v šoli izbrala le tretjina anketirancev ( $34 \%$ ). Udeležba na tečajih (predvsem so tu mišljena odprta izobraževanja oziroma M O O C - angl. Massive Open Online Course) je za preučevano populacijo popolnoma nezanimiva, kajti to možnost je izbral le en dijak. To seveda ne pomeni, da takega na- 
Preglednica 5.2 Aktivnosti dijakov na internetu

\begin{tabular}{|c|c|c|}
\hline Aktivnost & (1) & $(2)$ \\
\hline $\begin{array}{l}\text { Komunikacija s prijatelji prek sporočil (Skype, Whatsapp, Messenger, } \\
\text { Google Talk, Snapchat ...) }\end{array}$ & 434 & 89 \\
\hline $\begin{array}{l}\text { Iskanje informacij za osebno rabo in/ali šolo (novice, vremenska na- } \\
\text { poved, članki, študij ...) }\end{array}$ & 398 & 81 \\
\hline Poslušanje glasbe in gledanje filmov & 396 & 81 \\
\hline Dostop in uporaba socialnih omrežij (F B, T w, Google+, Linkedin ...) & 349 & 71 \\
\hline Pošiljanje in prejemanje e-pošte & 269 & 55 \\
\hline Prenos aplikacij in/ali multimedijskih vsebin & 258 & 53 \\
\hline Spletno nakupovanje & 162 & 33 \\
\hline $\begin{array}{l}\text { Sodelovanje s sošolci prek uporabe deljenih dokumentov (Google } \\
\text { Drive, Sites, Scoop.it ...) }\end{array}$ & 123 & 25 \\
\hline Uporaba storitev v oblaku (Dropbox, Google Drive ...) & 121 & 25 \\
\hline Nalaganje in deljenje svojih multimedijskih vsebin & 80 & 16 \\
\hline Sodelovanje v forumih & 53 & 11 \\
\hline Komuniciranje s pomočjo videokonferenc & 29 & 6 \\
\hline Drugo & 21 & 4 \\
\hline Pisanje lastnega dnevnika (bloga) & 14 & 3 \\
\hline
\end{tabular}

O Р Ом В E Naslovi stolpcev: (1) število dijakov, (2) delež dijakov v odstotkih.

Preglednica 5.3 Načini pridobivanja ali raven znanja s področja IKT

\begin{tabular}{lrr}
\hline Način pridobivanja znanja s področja I K T & $(1)$ & $(2)$ \\
\hline Samoučenje s pomočjo virov, dostopnih na spletu & 253 & 52 \\
V procesu šolanja & 169 & 34 \\
Z udeležbo na tečajih & 1 & 0 \\
Moje znanje o IKT je šibko & 47 & 10 \\
Drugo & 15 & 3 \\
\hline
\end{tabular}

О Р Ом Ве Naslovi stolpcev: (1) število dijakov, (2) delež dijakov v odstotkih.

čina izobraževanja ne uporabljajo, le opredelijo ga ne kot prednostni način izobraževanja. Zanimiv je podatek, da je kar desetina dijakov svoje znanje s področja I K T označila za šibko, navkljub vsem omenjenim možnostim pridobivanja. Dijaki, ki so kot možnost izbrali Drugo, so navajali pridobivanje znanja v krogu svoje družine, prijateljev ali pa s poskušanjem.

Vključevanje rabe I K T je bila ena prednostnih nalog prenove izobraževalnih programov, zato nas je zanimalo, kako pogosto dijaki pri delu v šoli uporabljajo I K T (preglednica 5.4).

Rezultati kažejo precejšnjo rabo I K T pri delu v šoli, kajti kar polovica 
Preglednica 5.4 Uporaba I K T pri delu v šoli

\begin{tabular}{lrr}
\hline Pogostost rabe IKT pri delu v šoli & $(1)$ & $(2)$ \\
\hline Vsak dan & 105 & 21 \\
Nekajkrat tedensko & 247 & 50 \\
Nekajkrat mesečno & 91 & 19 \\
Nekajkrat letno & 24 & 5 \\
Drugo & 19 & 4 \\
\hline
\end{tabular}

O Р Ом в E Naslovi stolpcev: (1) število dijakov, (2) delež dijakov v odstotkih.

Preglednica 5.5 Število predmetov, kjer uporabljajo I K T

\begin{tabular}{lrr}
\hline Raba I T po predmetih & $(1)$ & $(2)$ \\
\hline Vsi predmeti & 33 & 7 \\
Polovica predmetov & 80 & 16 \\
Četrtina predmetov & 99 & 20 \\
Eden ali dva predmeta & 206 & 42 \\
Noben predmet & 17 & 3 \\
\hline
\end{tabular}

OP Oм в E Naslovi stolpcev: (1) število dijakov, (2) delež dijakov v odstotkih.

dijakov (50\%) jo tam uporablja nekajkrat tedensko, medtem ko petina (21\%) I K T v šoli uporablja vsak dan. Ti rezultati kažejo tudi na dobro opremljenost naših šol z I K T, kar je lahko osnova za drugačne metode poučevanja in učenja. Presenetljivo je, da v gimnazijskem programu, ki je osnova za nadaljnji študij, kar petina dijakov (19\%) I K T uporablja le nekajkrat mesečno. Pod Drugo so dijaki navajali še zelo raznolike odgovore, kot so: vsako uro, enkrat na teden ali pa celo nikoli.

Prenovljeni učni načrti so predvidevali spodbujanje digitalne pismenosti prek rabe I K T pri vseh predmetih, zato nas je zanimalo, pri koliko predmetih uporabljajo IKT (preglednica 5.5).

Tu rezultati niso več spodbudni, kajti skoraj polovica ( $42 \%)$ dijakov navaja, da I к T uporabljajo le pri enem ali dveh predmetih. Le $7 \%$ dijakov I K T uporablja pri vseh predmetih v šoli, medtem ko $3 \%$ dijakov navajajo, da IKT sploh ne uporabljajo (preglednica 5.5).

\subsection{Analiza podatkov o digitalni pismenosti}

Kot smo že omenili, smo digitalno pismenost dijakov gimnazijskih programov preverjali po modelu D CA. Vprašanja smo razdelili na tri področja, in sicer na tehnološko (7 vprašanj), kognitivno (10 vprašanj) in etično (13 vprašanj). Vsako področje je bilo točkovano z do 20 točkami. Vprašanja, kjer je bilo možno podati več odgovorov, pa so bila v primeru 
Preglednica 5.6 Porazdelitev skupnih rezultatov merjenja digitalne pismenosti

\begin{tabular}{lrr}
\hline Kriterij uspešnosti & $(1)$ & $(2)$ \\
\hline Manj kot 25\% & 0 & 0,0 \\
Med 25\% in 50\% & 75 & 15,3 \\
Med 50\% in 75\% & 352 & 71,8 \\
Več kot 75\% & 63 & 12,9 \\
\hline
\end{tabular}

OP Ом В E Naslovi stolpcev: (1) število dijakov, (2) delež dijakov v odstotkih.

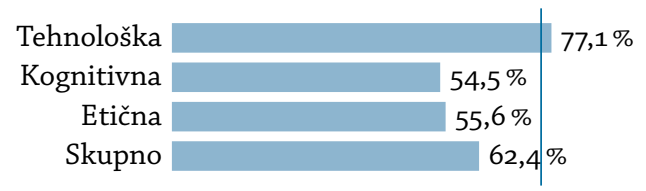

Slika $5 \cdot 3$ Povprečna uspešnost dijakov po posameznih dimenzijah (75\% - digitalno pismen dijak)

nepravilnega odgovora točkovana negativno. Uspešnost anketirancev prikazujemo v preglednici 5.6.

Povprečni doseženi rezultat dijaka pri merjenju digitalne pismenosti je bil 62,4\%, kar je pod mejo, ki je bila določena za pozitivni rezultat (75\%). Mejni prag $75 \%$ je doseglo le 63 anketiranih dijakov oziroma $12,9 \%$. Če prag uspešnosti spustimo na $60 \%$ vseh točk, se uspeh poviša na 296 dijakov oziroma 60,4\%.

Pogledali smo še skupne rezultate po posameznih dimenzijah (slika 5.3). Ti nam pokažejo, da je bil pričakovano najboljši rezultat v povprečju pri tehnološki dimenziji, in sicer $77,1 \%$. Bistveno slabša rezultata sta pri kognitivni $(54,5 \%)$ in etični dimenziji $(55,6 \%)$. Rezultati nam povedo, da dijaki dobro poznajo osnovna tehnična opravila in znajo reševati tehnične probleme, medtem ko na področjih povezovanja informacij v višje miselne procese in razumevanja etične rabe interneta rezultati zaostajajo za pričakovanimi.

V nadaljevanju smo preverili skupne rezultate še po demografskih spremenljivkah (preglednica 5.7), medtem ko smo statistično značilne razlike preverjali v poglavju 6.4 .

$\mathrm{Na}$ podlagi skupnih rezultatov po posameznih demografskih spremenljivkah lahko ugotovimo, da so fantje v povprečju dosegli za $3 \%$ boljši rezultat. Precej boljši rezultat so $\mathrm{v}$ povprečju dosegli pri tehnološki in etični dimenziji.

Čeprav so dijaki strokovnih gimnazij v povprečju dosegli za $1 \%$ boljši skupni rezultat od dijakov splošnih gimnazijskih programov, te razlike 
Preglednica 5.7 Digitalna pismenost glede na demografske značilnosti

\begin{tabular}{llrrrrrr}
\hline Spremenljivka & & $(1)$ & $(2)$ & $(3)$ & $(4)$ & $(5)$ & $(6)$ \\
\hline \multirow{2}{*}{ Spol } & Moški & 255 & 15,62 & 10,90 & 11,47 & 37,98 & 6,51 \\
& Ženski & 235 & 15,21 & 10,90 & 10,75 & 36,87 & 6,68 \\
\hline \multirow{2}{*}{ Vrsta gimnazije } & Splošna & 343 & 15,38 & 10,83 & 11,06 & 37,26 & 6,74 \\
& Strokovna & 147 & 15,53 & 11,06 & 11,28 & 37,88 & 6.30 \\
\hline Letnik šolanja & 1. letnik & 321 & 14,86 & 11,24 & 11,21 & 37,31 & 6,64 \\
& 4. letnik & 167 & 16,49 & 10,26 & 10,96 & 37,71 & 6,57 \\
\hline \multirow{2}{*}{ Geografska regija } & Vzhodna Slovenija & 260 & 15,44 & 11,12 & 11,29 & 37,84 & 6,32 \\
& Zahodna Slovenija & 230 & 15,41 & 10,65 & 10,94 & 37,00 & 6,91 \\
\hline
\end{tabular}

OP Ом BE Naslovi stolpcev: (1) število dijakov, (2) tehnološka dimenzija, (3) kognitivna dimenzija, (4) etična dimenzija, (5) povprečna vrednost, (6) standardni odklon.

niso statistično značilne. Zanimale pa so nas razlike med rezultati prvega in zadnjega letnika šolanja, kajti le-te so bili pokazatelj razvoja digitalne pismenosti v obdobju srednješolskega izobraževanja. Skupni rezultati dijakov 4. letnika so bili v povprečju boljši za $1 \%$, presenetljiva pa je struktura po dimenzijah. Največjo razliko opazimo pri tehnološki dimenziji, kjer so dijaki 4. letnika v povprečju dosegli za 10,9\% boljši rezultat, medtem ko so tako v kognitivni $(-8,8 \%)$ in etični $(-2,3 \%)$ dimenziji nazadovali. Sklepamo lahko, da v procesu srednješolskega šolanja dijaki pridobivajo izkušnje pri reševanju osnovnih tehničnih težav s strojno ali programsko opremo, medtem ko na področju logičnega sklepanja, povezovanja podatkov $\mathrm{v}$ nova znanja in prepoznavanju digitalnega razkoraka ne napredujejo. Dijaki iz vzhodne Slovenije so v povprečju dosegli za 2,2\% boljši rezultat. Za proces izobraževanja je zanimiva tudi ugotovitev, da so dijaki, ki znanje s področja IKT pridobivajo samostojno s pomočjo virov na spletu, v povprečju dosegli za 3,6\% boljši rezultat kot dijaki, ki ga v večji meri pridobivajo v procesu šolanja. Poleg demografskih smo preverili še rezultate po drugih spremenljivkah: glede na način pridobivanja znanja iz IKT, pogostosti rabe I K T V šoli in številu predmetov v šoli, pri katerih uporabljajo I K T (preglednica 5.8).

Na kognitivnem in etičnem področju so najboljši rezultat v povprečju dosegli dijaki, ki I K T v šoli uporabljajo nekajkrat mesečno, kar tudi pomeni, da pri preučevani populaciji raba IK T v šoli ne spodbuja višjih miselnih procesov in etične rabe interneta.

Dijaki, ki I T T uporabljajo pri vseh predmetih, dosegajo v povprečju najboljši rezultat pri tehnološki dimenziji, medtem ko pri kognitivni in 
Preglednica 5.8 Digitalna pismenost glede na način pridobivanja znanja in pogostost rabe I K T

\begin{tabular}{llrrrrrr}
\hline Spremenljivka & $(1)$ & $(2)$ & $(3)$ & $(4)$ & $(5)$ & $(6)$ \\
\hline $\begin{array}{l}\text { Način pri- } \\
\text { dobivanja }\end{array}$ & Proces šolanja & 169 & 15,05 & 10,69 & 10,89 & 36,63 & 6,82 \\
I T T znanja & namoučenje (viri & 257 & 15,77 & 10,99 & 11,20 & 37,96 & 6,60 \\
& npletu) & 105 & 15,12 & 10,89 & 10,85 & 36,87 & 7,15 \\
\hline Uporaba & Vsak dan & 247 & 15,55 & 10,97 & 11,16 & 37,68 & 6,70 \\
& Nekajkrat tedensko & 91 & 15,18 & 10,22 & 11,81 & 38,20 & 5,88 \\
& Nekajkrat mesečno & 24 & 16,67 & 9,99 & 10,53 & 37,19 & 6,24 \\
\hline Nekajkrat letno & 33 & 16,07 & 10,47 & 10,60 & 37,15 & 6,93 \\
Št. pred- & Vsi predmeti & 89 & 15,21 & 11,02 & 11,33 & 37,56 & 6,90 \\
metov, kjer & Polovica predmetov & 109 & 15,63 & 11,02 & 11,69 & 38,35 & 6,88 \\
se uporab- & Četrtina predmetov & 239 & 15,43 & 10,72 & 10,78 & 36,93 & 6,41 \\
lja I K T & 1 ali 2 predmeta & 18 & 14,18 & 12,68 & 12,47 & 39,34 & 5,24 \\
\hline
\end{tabular}

О Р Ом ве Naslovi stolpcev: (1) število dijakov, (2) tehnološka dimenzija, (3) kognitivna dimenzija, (4) etična dimenzija, (5) povprečna vrednost, (6) standardni odklon.

etični dimenziji najboljši rezultat dosegajo dijaki, ki I K T ne uporabljajo pri nobenem predmetu.

V naslednjem koraku smo pri analizi rezultatov pogledali rezultate pri posameznih znanjih in veščinah (preglednica 5.9), kot jih opredeli model D C A. V vprašalniku (priloga 3 ) se je namreč vsako v modelu opredeljeno znanje ali veščina preverjalo s sklopom vprašanj. Opis posameznih znanj in veščin modela D CA smo predstavili v razdelku Cilji in sestava okvira DIG COMP. Primerjava doseženih rezultatov v preglednici 5.9 pokaže jasno prevlado znanj in spretnosti tehnološke dimenzije, pa čeprav mejo $75 \%$ presega le vizualna pismenost.

Visoka uspešnost pri vizualni pismenosti ( $93,9 \%$ točk) pomeni visoko raven znanja preučevanih dijakov pri prepoznavanju simbolov, ikon in uporabniških vmesnikov najbolj uporabljane programske opreme. Tako visok rezultat lahko pripišemo vsakodnevni rabi IK T in enotni rabi posameznih simbolov za pričakovane funkcije posamezne programske opreme.

Področje reševanja problemov se pri raziskavi nanaša na probleme, povezane $s$ tehnologijo oziroma $z$ delovanjem računalnika in zunanjih enot, ki jih v računalnike priključimo. Uspešnost pri reševanju teh vprašanj znaša v povprečju $69,9 \%$ točk, kar je zelo nizek rezultat, saj so bila vprašanja vezana le na osnovne problemske situacije. Podobno je bilo 
5 Raziskava digitalne pismenosti

Preglednica 5.9 Doseženi rezultati znanj in veščin po modelu D CA

\begin{tabular}{llr}
\hline Dimenzija & Znanje ali veščina & $(1)$ \\
\hline Tehnološka & Vizualna pismenost & 93,9 \\
& Razumevanje tehnoloških konceptov & 70,5 \\
& Reševanje problemov & 69,9 \\
\hline \multirow{2}{*}{ Kognitivna } & Organizacija in povezovanje besedilnih in vizualnih podatkov & 56,1 \\
& Strukturiranje pridobljenih podatkov & 54,3 \\
& Iskanje informacij & 53,0 \\
\hline Etična & Družbeno-kulturni vpliv tehnologije & 56,2 \\
& Spoštovanje drugih & 69,3 \\
& Varovanje zasebnosti & 52,0 \\
\hline
\end{tabular}

OP OMBE Naslovi stolpcev: (1) delež v odstotkih.

tudi pri razumevanju tehnoloških konceptov, kjer smo preverjali, koliko dijaki poznajo osnovna sporočila in možne vzroke nedelovanja računalnika. Rezultat je tudi pri tem področju podoben prejšnjemu, in sicer $\mathrm{v}$ povprečju 70,5\% pravilno rešenih vprašanj.

Področja, povezana z znanji o etičnem ravnanju, so dosegla bistveno nižje povprečne rezultate. Najproblematičnejše je področje varovanja zasebnosti, kjer zaradi povprečnega rezultata ( 52 \%) lahko sklepamo, da se dijaki ne zavedajo dovolj možnih posledic objave osebnih podatkov na spletu. Prav tako nimajo dovolj dobre predstave o t. i. tehnološki vrzeli oziroma o digitalnem razkoraku in vplivu tehnologije na družbene potenciale (povprečni rezultat $56,2 \%$ ). Še najboljši rezultat pri preverjanju znanja etičnega ravnanja so dijaki dosegli pri spoštovanju drugih uporabnikov s povprečno 69,3 odstotno uspešnostjo.

Komaj malce več kot polovična uspešnost se je pokazala pri preverjanju veščin, ki se nanašajo na miselne procese ustvarjanja, povezovanja in grafičnega prikaza podatkov ( 56,1 odstotna povprečna uspešnost), analiziranja in strukturiranja pridobljenih podatkov (54,3odstotna povprečna uspešnost) in kritičnega vrednotenja pridobljenih informacij (53 odstotna povprečna uspešnost).

\subsection{Preverjanje hipotez}

V uvodu smo zastavili štiri hipoteze, ki jih želimo preveriti z raziskavo. Kot omenjeno, smo pri merjenju digitalne pismenosti upoštevali okvir D CA, na podlagi katerega smo spremenljivke razdelili v tri dimenzije tehnološko, kognitivno in etično.

S hipotezo 1 smo želeli preveriti, ali obstaja statistično značilna pove- 
zanost med intenzivnostjo uporabe I K T pri pouku in stopnjo digitalne pismenosti dijakov gimnazijskih programov.

Za potrjevanje hipoteze 1 si zastavimo dve delovni hipotezi (če bo stopnja statistične značilnosti manjša od o,05, ničelne hipoteze ne sprejmemo in potrdimo alternativno hipotezo):

Ho med spremenljivkama ni statistično značilne povezanosti.

H1 med spremenljivkama obstaja statistično značilna povezanost.

Za testiranje prve hipoteze smo uporabili Spearmanov koeficient korelacije, s katerim smo ugotavljali, ali intenzivnost uporabe $\mathrm{I} \mathrm{K} \mathrm{T}$ v šoli prispeva k digitalni pismenosti dijakov. Preverili smo povezanost med spremenljivko Digitalna pismenost in spremenljivkama Pogostost uporabe IKT v šoli $(p=0,69)$ ter Pri kolikih predmetih uporabljate IK T ( $p=$ $0,51)$ in ugotovili, da ne obstaja statistično značilna povezanost. Ker je vrednost stopnje statistične značilnosti večja od o,05, ničelne hipoteze ne moremo zavreči in sprejeti hipoteze 1. Med intenzivnostjo uporabe I K T pri pouku in digitalno pismenostjo dijakov ni statistično značilne povezanosti, prav tako tudi višja intenzivnost uporabe IK T pri pouku ni statistično značilno povezana $\mathrm{z}$ rezultatom digitalne pismenosti dijakov.

Pri hipotezi 2 smo trdili, da dijaki strokovnih gimnazij pri posameznih dimenzijah digitalne pismenosti v povprečju dosegajo boljši rezultat od dijakov splošnih gimnazij.

Pred začetkom testiranja hipoteze smo preverili, ali je spremenljivka Vrsta gimnazijskega programa (splošna gimnazija in strokovna gimnazija) normalno porazdeljena. Normalnost porazdelitve vpliva na izbiro testa za ugotavljanje razlike med gimnazijskima programoma.

Za ugotavljanje normalnosti porazdelitve spremenljivke Vrsta gimnazijskega programa si zastavimo dve delovni hipotezi, in sicer:

Ho porazdelitev ne odstopa od statistično značilno normalne porazdelitve.

H1 porazdelitev odstopa od statistično značilno normalne porazdelitve.

Če bo statistična značilnost manjša od o,05, ničelno hipotezo ovržemo in potrdimo alternativno hipotezo.

Kot vidimo v preglednici 5.10, so statistične značilnosti obeh testov (Kolmogorov-Smirnov in Shapiro-Wilk) povsod manjše od o,05, kar pomeni, da ne sprejmemo ničelne hipoteze in potrdimo alternativno, ki pravi, da porazdelitve statistično značilno odstopajo od normalne porazdelitve. Zato bomo v nadaljevanju za ugotavljanje razlik v dimenzi- 
Preglednica 5.10 Preverjanje normalnosti porazdelitve spremenljivke

\begin{tabular}{|c|c|c|c|c|c|c|c|}
\hline \multirow{2}{*}{$\begin{array}{l}\text { Dimenzije digi- } \\
\text { talne pismenosti }\end{array}$} & \multirow{2}{*}{$\begin{array}{l}\text { Gimnazijski } \\
\text { program }\end{array}$} & \multicolumn{3}{|c|}{ Kolmogorov-Smirnov } & \multicolumn{3}{|c|}{ Shapiro-Wilk } \\
\hline & & (1) & (2) & (3) & (1) & (2) & (3) \\
\hline \multirow[t]{2}{*}{ Tehnološka } & Splošni & 0,089 & 343 & 0,000 & 0,954 & 343 & 0,000 \\
\hline & Strokovni & 0,124 & 147 & 0,000 & 0,946 & 147 & 0,000 \\
\hline \multirow[t]{2}{*}{ Kognitivna } & Splošni & 0,062 & 343 & 0,003 & 0,987 & 343 & 0,004 \\
\hline & Strokovni & 0,079 & 147 & 0,026 & 0,973 & 147 & 0,006 \\
\hline \multirow[t]{2}{*}{ Etična } & Splošni & 0,095 & 343 & o,००० & 0,988 & 343 & 0,006 \\
\hline & Strokovni & 0,109 & 147 & 0,000 & 0,975 & 147 & 0,009 \\
\hline
\end{tabular}

OPOMBE Naslovi stolpcev: (1) statistika, (2) stopnje prostosti, (3) stopnja značilnosti.

Preglednica 5.11 Povprečni rang za spremenljivke dimenzije digitalne pismenosti

\begin{tabular}{lllll}
\hline $\begin{array}{l}\text { Dimenzije digitalne } \\
\text { pismenosti }\end{array}$ & $\begin{array}{l}\text { Gimnazijski } \\
\text { program }\end{array}$ & $N$ & Povp. rang & Vsota ranga \\
\hline Tehnološka dimenzija & Splošni & 343 & 243,67 & 83580,00 \\
& Strokovni & 147 & 249,76 & 36715,00 \\
& Skupaj & 490 & & \\
\hline Kognitivna dimenzija & Splošni & 343 & 242,19 & 83070,00 \\
& Strokovni & 147 & 253,23 & 37225,00 \\
& Skupaj & 490 & & \\
\hline Etična dimenzija & Splošni & 343 & 241,08 & 82690,50 \\
& Strokovni & 147 & 255,81 & 37604,50 \\
& Skupaj & 490 & & \\
\hline
\end{tabular}

jah digitalne pismenosti glede na gimnazijski program, uporabili neparametrični Mann-Whitney test.

Povprečni rang (preglednica 5.11) je pri tehnološki dimenziji nekoliko višji pri strokovnem gimnazijskem programu (249,76), prav tako je povprečni rang nekoliko višji pri strokovnem gimnazijskem programu v primeru kognitivne $(253,23)$ in etične dimenzije digitalne pismenosti $(255,81)$, zato bomo v nadaljevanju preverili, ali so razlike glede na gimnazijski program tudi statistično značilne.

Za ugotavljanje razlik med dvema skupinama, Vrsta gimnazijskega programa in Dimenzija digitalne pismenosti, si zastavimo dve delovni hipotezi:

но med skupinama ni statistično značilnih razlik.

H1 med skupinama so statistično značilne razlike.

Iz preglednice 5.12 vidimo, da so statistične značilnosti pri vseh treh 
Preglednica 5.12 Testne statistike za spremenljivko Vrste gimnazijskega programa

\begin{tabular}{lrlrr}
\hline $\begin{array}{l}\text { Dimenzije digitalne } \\
\text { pismenosti }\end{array}$ & $\begin{array}{r}\text { Mann- } \\
\text { Whitney } U\end{array}$ & Wilcoxon $W$ & $Z$ & $\begin{array}{r}\text { Stop. znač. } \\
(2 \text {-stranska) }\end{array}$ \\
\hline Tehnološka dimenzija & 24584,000 & 83580,000 & $-0,437$ & 0,662 \\
Kognitivna dimenzija & 24074,000 & 83070,000 & $-0,792$ & 0,429 \\
Etična dimenzija & 23694,500 & 82690,500 & $-1,059$ & 0,289 \\
\hline
\end{tabular}

dimenzijah digitalne pismenosti večje od o,05 (tehnološka o,662, kognitivna 0,429 , etična 0,289 ), zato ničelne hipoteze ne moremo ovreči, kar pomeni, da glede na gimnazijski program na posameznih področjih digitalne pismenosti ne obstajajo statistično pomembne razlike.

Hipoteze 2 na podlagi analize ne sprejmemo in sklepamo, da glede na vrsto gimnazijskega programa ni statistično značilnih razlik v digitalni pismenosti dijakov po posameznih dimenzijah.

Pri hipotezi 3 smo preverjali, ali obstajajo statistično značilne razlike $\mathrm{v}$ posameznih dimenzijah digitalne pismenosti glede na spol.

Za ugotavljanje normalnosti porazdelitve spremenljivke Spol smo zastavili dve delovni hipotezi, in sicer:

Ho porazdelitev ne odstopa statistično značilno od normalne.

H1 porazdelitev odstopa statistično značilno od normalne.

Če bo statistična značilnost manjša od o,05, bomo ničelno hipotezo ovrgli, sicer pa potrdili alternativno hipotezo.

Kot vidimo iz preglednice 5.13 , je statistična značilnost obeh testov pri tehnološki in etični dimenziji manjša od o,05, kar pomeni, da ničelno hipotezo ovržemo in sprejmemo alternativno. To pomeni, da porazdelitvi odstopata od normalne. Pri kognitivni dimenziji vidimo, da je spremenljivka za ženske približno normalno porazdeljena, za moške pa to ne drži ( $p=0,000$ pri obeh testih). Zato bomo v nadaljevanju uporabili Mann-Whitney test za ugotavljanje razlik v dimenzijah digitalne pismenosti glede na spol.

Povprečni rang (preglednica 5.14) je pri tehnološki, kognitivni in etični dimenziji nekoliko višji pri moških, zato bomo v nadaljevanju preverili, ali so razlike glede na spol tudi statistično značilne.

Iz analize (preglednica 5.15) je razvidno, da so statistične značilnosti pri dveh dimenzijah digitalne pismenosti večje od o,05 (tehnološka o,112, kognitivna o,803), zato ničelne hipoteze ne moremo ovreči. Sklepamo lahko, da pri tehnološki in kognitivni dimenziji ne obstajajo stati- 
Preglednica 5.13 Preverjanje normalnosti porazdelitve za spremenljivko Spol

\begin{tabular}{|c|c|c|c|c|c|c|c|}
\hline \multirow{2}{*}{$\begin{array}{l}\text { Dimenzije digi- } \\
\text { talne pismenosti }\end{array}$} & \multirow{2}{*}{$\begin{array}{l}\text { Gimnazijski } \\
\text { program }\end{array}$} & \multicolumn{3}{|c|}{ Kolmogorov-Smirnov } & \multicolumn{3}{|c|}{ Shapiro-Wilk } \\
\hline & & (1) & (2) & (3) & (1) & (2) & (3) \\
\hline \multirow[t]{2}{*}{ Tehnološka } & Moški & 0,115 & 255 & 0,000 & 0,942 & 255 & 0,000 \\
\hline & Ženski & 0,087 & 235 & 0,000 & 0,961 & 235 & 0,000 \\
\hline \multirow[t]{2}{*}{ Kognitivna } & Moški & 0,081 & 255 & 0,000 & 0,978 & 255 & 0,000 \\
\hline & Ženski & 0,059 & 235 & 0,044 & 0,989 & 235 & 0,065 \\
\hline \multirow[t]{2}{*}{ Etična } & Moški & 0,085 & 255 & 0,000 & 0,980 & 255 & 0,001 \\
\hline & Ženski & 0,106 & 235 & 0,000 & 0,984 & 235 & 0,009 \\
\hline
\end{tabular}

OPOMBE Naslovi stolpcev: (1) statistika, (2) stopnje prostosti, (3) stopnja značilnosti.

Preglednica 5.14 Povprečni rang za spremenljivko Spol

\begin{tabular}{lllll}
\hline $\begin{array}{l}\text { Dimenzije digitalne } \\
\text { pismenosti }\end{array}$ & $\begin{array}{l}\text { Gimnazijski } \\
\text { program }\end{array}$ & $N$ & Povp. rang & Vsota ranga \\
\hline Tehnološka dimenzija & Moški & 255 & 255,25 & 65087,50 \\
& Ženski & 235 & 234,93 & 55207,50 \\
& Skupaj & 490 & & \\
\hline Kognitivna dimenzija & Moški & 255 & 247,03 & 62993,50 \\
& Ženski & 235 & 243,84 & 57301,50 \\
& Skupaj & 490 & & \\
\hline Etična dimenzija & Moški & 255 & 263,20 & 67117,00 \\
& Ženski & 235 & 226,29 & 53178,00 \\
& Skupaj & 490 & & \\
\hline
\end{tabular}

Preglednica 5.15 Testne statistike za spremenljivko Spol

\begin{tabular}{lrrrr}
\hline $\begin{array}{l}\text { Dimenzije digitalne } \\
\text { pismenosti }\end{array}$ & $\begin{array}{r}\text { Mann- } \\
\text { Whitney } U\end{array}$ & Wilcoxon $W$ & $Z$ & $\begin{array}{r}\text { Stop. znač. } \\
(2 \text {-stranska) }\end{array}$ \\
\hline Tehnološka dimenzija & 27477,500 & 55207,500 & $-1,590$ & 0,112 \\
Kognitivna dimenzija & 29571,500 & 57301,500 & $-0,2500$ & 0,803 \\
Etična dimenzija & 25448,000 & 53178,000 & $-2,893$ & 0,004 \\
\hline
\end{tabular}

stično pomembne razlike med spoloma. Pri etični dimenziji pa vidimo, da je statistična značilnost manjša od $0,05(p=0,004)$, kar pomeni, da ničelno hipotezo ovržemo in sprejmemo alternativno.

Hipotezo 3 tako delno sprejmemo, saj na osnovi analize lahko sklepamo, da med spoloma obstajajo statistično značilne razlike pri etični dimenziji digitalne pismenosti. Pri ostalih dveh dimenzijah (tehnološka in kognitivna) razlike niso statistično značilne.

Shipotezo 4 smo želeli preveriti, ali obstajajo statistično značilne raz- 
Preglednica 5.16 Preverjanje normalnosti porazdelitve spremenljivke Regija

\begin{tabular}{|c|c|c|c|c|c|c|c|}
\hline \multirow{2}{*}{$\begin{array}{l}\text { Dimenzije digi- } \\
\text { talne pismenosti }\end{array}$} & \multirow{2}{*}{$\begin{array}{l}\text { Gimnazijski } \\
\text { program }\end{array}$} & \multicolumn{3}{|c|}{ Kolmogorov-Smirnov } & \multicolumn{3}{|c|}{ Shapiro-Wilk } \\
\hline & & (1) & (2) & (3) & (1) & (2) & (3) \\
\hline \multirow[t]{2}{*}{ Tehnološka } & Vzhodna & 0,094 & 260 & o,००० & 0,960 & 260 & o,००० \\
\hline & Zahodna & 0,113 & 230 & 0,000 & 0,944 & 230 & 0,000 \\
\hline \multirow[t]{2}{*}{ Kognitivna } & Vzhodna & 0,066 & 260 & 0,008 & 0,987 & 260 & 0,016 \\
\hline & Zahodna & 0,082 & 230 & 0,001 & 0,981 & 230 & 0,004 \\
\hline \multirow[t]{2}{*}{ Etična } & Vzhodna & 0,097 & 260 & 0,000 & 0,987 & 260 & 0,016 \\
\hline & Zahodna & 0,090 & 230 & 0,000 & 0,981 & 230 & 0,003 \\
\hline
\end{tabular}

OP OMB E Naslovi stolpcev: (1) statistika, (2) stopnje prostosti, (3) stopnja značilnosti.

Preglednica 5.17 Povprečni rang za spremenljivko Regija

\begin{tabular}{lllll}
\hline $\begin{array}{l}\text { Dimenzije digitalne } \\
\text { pismenosti }\end{array}$ & $\begin{array}{l}\text { Gimnazijski } \\
\text { program }\end{array}$ & $N$ & Povp. rang & Vsota ranga \\
\hline Tehnološka dimenzija & Vzhodna & 260 & 243,20 & 63231,00 \\
& Zahodna & 230 & 248,10 & 57064,00 \\
& Skupaj & 490 & & \\
\hline Kognitivna dimenzija & Vzhodna & 260 & 252,32 & 65604,00 \\
& Zahodna & 230 & 237,79 & 54691,00 \\
& Skupaj & 490 & & \\
\hline Etična dimenzija & Vzhodna & 260 & 250,42 & 65109,50 \\
& Zahodna & 230 & 239,94 & 55185,50 \\
& Skupaj & 490 & & \\
\hline
\end{tabular}

like $\mathrm{v}$ posameznih dimenzijah digitalne pismenosti glede na regijo, $\mathrm{v}$ kateri se izvaja gimnazijski program.

Tudi pred začetkom testiranja četrte hipoteze smo preverili, ali so spremenljivke, ki jih bomo uporabili v analizi (zahodna ali vzhodna regija), normalno porazdeljene. Statistična značilnost opravljenih testov (preglednica 5.16) je pokazala (stopnja značilnosti < 0,005), da ničelno hipotezo lahko ovržemo in sprejmemo alternativno hipotezo. To pomeni, da porazdelitve glede na regijo odstopajo od normalne.

Povprečni rang je pri tehnološki dimenziji (preglednica 5.17) nekoliko višji pri zahodni regiji $(248,10)$, pri kognitivni in etični dimenziji pa je višji v vzhodni regiji. Ker vidimo, da so razlike prisotne, bomo v nadaljevanju preverili, ali so glede na regijo, $v$ kateri se izvaja gimnazijski program, tudi statistično značilne.

Iz preglednice 5.18 vidimo, da so statistične značilnosti pri vseh treh 
Preglednica 5.18 Testne statistike za spremenljivko Regija

\begin{tabular}{lrrrr}
\hline $\begin{array}{l}\text { Dimenzije digitalne } \\
\text { pismenosti }\end{array}$ & $\begin{array}{r}\text { Mann- } \\
\text { Whitney } U\end{array}$ & Wilcoxon $W$ & $Z$ & $\begin{array}{r}\text { Stop. znač. } \\
(2 \text {-stranska) }\end{array}$ \\
\hline Tehnološka dimenzija & 29301,000 & 63231,000 & $-0,384$ & 0,701 \\
Kognitivna dimenzija & 28126,000 & 54691,000 & $-1,135$ & 0,257 \\
Etična dimenzija & 28620,500 & 55185,500 & $-0,821$ & 0,412 \\
\hline
\end{tabular}

Preglednica 5.19 Medsebojna povezanost spremenljivk digitalne pismenosti

\begin{tabular}{|c|c|c|c|c|c|c|c|c|c|}
\hline Dimenzija & & (1) & (2) & (3) & (4) & (5) & (6) & (7) & $\overline{(8)}$ \\
\hline \multirow[t]{3}{*}{ Tehnološka } & (1) & & & & & & & & \\
\hline & (2) & $0,22^{* *}$ & & & & & & & \\
\hline & (3) & $0,18^{* *}$ & $0,17^{* *}$ & & & & & & \\
\hline \multirow[t]{3}{*}{ Kognitivna } & (4) & & & & & & & & \\
\hline & (5) & & & & $0,31^{* *}$ & & & & \\
\hline & (6) & & & & $0,25^{* *}$ & $0,29^{* *}$ & & & \\
\hline \multirow[t]{3}{*}{ Etična } & (7) & & & & & & & & \\
\hline & (8) & & & & $0,26^{* *}$ & $0,24^{* *}$ & $0,34^{* *}$ & & \\
\hline & (9) & & & & $0,12^{* *}$ & $0,11^{*}$ & & & $0,14^{* *}$ \\
\hline
\end{tabular}

OPOMBE Naslovi stolpcev/vrstic: (1) razumevanje tehnoloških konceptov, (2) reševanje problemov, (3) vizualna pismenost, (4) organizacija in povezovanje besedilnih in vizualnih podatkov, (5) strukturiranje pridobljenih podatkov, (6) iskanje informacij, (7) varovanje zasebnosti, (8) spoštovanje drugih, (9) družbeno-kulturni vpliv tehnologije. ${ }^{* *}$ Korelacija je značilna pri o,o1 (2-stransko). ${ }^{*}$ Korelacija je značilna pri o,05 (2-stransko).

dimenzijah digitalne pismenosti večje od o,05 (tehnološka o,701, kognitivna 0,257 , etična 0,412 ), zato ničelne hipoteze ne moremo ovreči, kar pomeni, da glede na regijo, v kateri se izvaja gimnazijski program, na posameznih področjih digitalne pismenosti ne prihaja do statistično pomembnih razlik.

Na podlagi analize podatkov hipoteze 4, ki trdi, da obstajajo statistično značilne razlike $\mathrm{v}$ digitalni pismenosti dijakov glede na regiji, ne moremo sprejeti.

V nadaljevanju analize nas je zanimala medsebojna povezanost posameznih spremenljivk znanja in veščin, ki jih določa model DCA (razdelek 3.2.1). V ta namen smo izvedli korelacijsko analizo (preglednica 5.19). Spremenljivke od 1 do 3 prikazujejo tehnološko dimenzijo, od 4 do 6 kognitivno in zadnje 3 etično dimenzijo modela D CA (preglednica 5.19).

Izračunani Pearsonovi korelacijski koeficienti prikazujejo posamezne 
statistično značilne povezave. Tako je razumevanje tehnoloških konceptov statistično značilno povezano $\mathrm{z}$ znanjem reševanja tehničnih problemov in $\mathrm{z}$ vizualno pismenostjo (korelacijski koeficient $=0,18$ ). Sklepamo lahko, da bolj kot dijak razume tehnološko delovanje računalnika in sporočila, ki mu jih $\mathrm{v}$ obliki sporočil o napakah računalnik izpiše na zaslon, lažje lahko rešuje problemske situacije, povezane $z$ delovanjem računalnika.

Spremenljivka Organizacija in povezovanje besedilnih in vizualnih podatkov je statistično značilno povezana s Strukturiranjem pridobljenih podatkov (o,31), z Iskanjem informacij (o,25), s Spoštovanjem drugih $(0,26)$ in z Družbeno-kulturnimi vplivi tehnologije $(0,12)$. Sklepamo lahko, da je dijak, ki je vešč iskanja informacij in njihovega strukturiranja oziroma razvrščanja po pomembnosti, vešč tudi povezovanja besedilnih in vizualnih informacij v nova znanja. Dijak, ki razume družbenokulturni vpliv tehnologije, posveča pomen tudi spoštovanju drugih uporabnikov.

Spremenljivka Družbeno-kulturni vpliv tehnologije je statistično značilno povezana s spremenljivkami Organizacija in povezovanje besedilnih in vizualnih podatkov $(0,12)$, Strukturiranje pridobljenih podatkov $(0,11)$ in Spoštovanje drugih $(0,14)$. Sklepamo lahko, da dijak, ki upošteva etična merila rabe interneta ob spoštovanju drugih uporabnikov, razume tudi družbeno-kulturni vpliv tehnologije. Veščina strukturiranja pridobljenih podatkov pa pripomore $\mathrm{k}$ njihovi lažji organizaciji in povezovanju.

Povezanost med vsemi naštetimi spremenljivkami je pozitivna, kar pomeni, da $\mathrm{z}$ naraščanjem vrednosti ene spremenljivke naraščajo tudi vrednosti druge. Vse navedene povezave so statistično značilne.

\subsection{Primerjava skupnih rezultatov z raziskavo digitalne pismenosti v Italiji}

Raziskava digitalne pismenosti v Italiji je potekala od septembhra 2009 do januarja 2010 na 34 srednjih šolah. Vključeni so bili vsi programi srednjih šol, srednjih strokovnih, programi strokovnih gimnazij in programih splošnih gimnazij. Povprečna starost anketirancev je bila 15 let. Neposredna primerljivost rezultatov zaradi krajšega vprašalnika v naši raziskavi ni povsem ustrezna, lahko pa iz rezultatov razberemo trende in značilnosti posameznih vzorcev.

Dosežen skupni povprečni rezultat $62,5 \%$ pri italijanski raziskavi je bil skoraj identičen povprečnemu rezultatu $\mathrm{v}$ slovenski raziskavi 
Preglednica 5.20 Primerjava porazdelitev skupnih rezultatov raziskav

\begin{tabular}{lrr}
\hline Delež & Italija & Slovenija \\
\hline Manj kot 25\% & 1 & 0 \\
Med 25\% in 50\% & 23 & 15 \\
Med 50\% in 75\% & 52 & 72 \\
Več kot 75\% & 24 & 13 \\
\hline
\end{tabular}

Preglednica 5.21 Povprečni rezultati po dimenzijah digitalne pismenosti

\begin{tabular}{lrr}
\hline Dimenzija & Italija & Slovenija \\
\hline Skupno & 62,5 & 62,4 \\
Tehnološka dimenzija & 73,6 & 77,1 \\
Kognitivna dimenzija & 57,3 & 54,5 \\
Etična dimenzija & 57,0 & 55,6 \\
\hline
\end{tabular}

$(62,4 \%)$. Kot lahko razberemo iz preglednice 5.20, je tudi skupna porazdelitev rezultatov podobna. $V$ italijanski raziskavi je bilo več dijakov, ki so dosegli manj kot $25 \%$ možnih točk, in tudi tistih, ki so dosegli med 25 in 50 \% točk ( $23 \%$ v Italiji, $15 \%$ v Sloveniji). Rezultati slovenskih srednješolcev so se najbolj zgostili v rangu med 50 in $75 \%$ ( $72 \%$ vseh dijakov), medtem ko jih je bilo pri italijanski raziskavi le $52 \%$. Zato pa so bili italijanski srednješolci uspešnejši pri najvišjem rangu (več kot 75-odstotna uspešnost), kjer je ta prag dosegla četrtina anketirancev (24\%), medtem ko ga je v Sloveniji le $13 \%$ dijakov.

Tudi primerjava doseženih rezultatov po posameznih dimenzijah pokaže podobnost obeh raziskav. Slovenski dijaki so bili v povprečju uspešnejši pri tehnološki dimenziji, kjer so dosegli za 3,5 odstotnih točk višji rezultat in so tudi v povprečju presegli mejo 75-odstotne uspešnosti. Pri kognitivni in etični dimenziji pa so bili italijanski dijaki v povprečju uspešnejši, vendar razlike niso velike.

Primerjava posameznih spremenljivk pokaže visoko raven vizualne pismenosti v obeh raziskavah. Pri prepoznavanju ikon in uporabniških vmesnikov najpogosteje uporabljane programske opreme so slovenski dijaki v povprečju dosegli 93,6-odstotno uspešnost, italijanski dijaki pa 88-odstotno. Pri organiziranju pridobljenih podatkov in iskanju manjkajoče vrednosti v tabeli so slovenski dijaki dosegli v povprečju 54 odstotnih točk, italijanski dijaki pa 43. Pri področju vrednotenja veljavnosti in relevantnosti najdenih informacij so bili uspešnejši italijanski dijaki, ki so dosegli v povprečju 61 odstotnih točk, medtem ko so jih slovenski dijaki dosegli le 53. Tudi na področju varne rabe interneta so 
bili italijanski dijaki uspešnejši, saj so dosegli za 9 odstotnih točk boljši rezultat. Za obe preučevani državi lahko ugotovimo, da dijaki ne prepoznavajo dovolj dobro tehnološkega razkoraka med razvitimi in nerazvitimi državami (povprečna uspešnost v Italiji je 44\%, v Sloveniji $55 \%$ ). Področje spoštovanja drugih uporabnikov interneta, kjer smo preverjali pogostost agresivnega izražanja in pravilnega citiranja avtorskih zapisov, je pokazalo 69-odstotno povprečno uspešnost v Sloveniji in 67odstotno povprečno uspešnost v Italiji. 



\section{Sklepna razmišljanja}

Znanje in veščine, povezane $\mathrm{z}$ rabo IKT, vplivajo na načine poučevanja in učenja ter kasneje postajajo osnovna potreba posameznika pri konkurenčnem vstopu na trg dela, sodelovanju v sodobni informacijski družbi in vseživljenjskem učenju.

$\mathrm{V}$ teoretičnem delu monografije smo najprej raziskovali razvoj pojmovanja digitalne pismenosti. Na osnovi študija literature ugotavljamo, da ni enotne opredelitve pojma, saj različni avtorji digitalno pismenost različno razumejo in jo tudi opredeljujejo različno. Skupno vsem opredelitvam pa je, da se pojmovanje digitalne pismenosti razvija skladno z razvojem tehnologije. Opredelitev znanj in veščin digitalne pismenosti se $\mathrm{z}$ začetnega bolj tehnološkega pogleda vedno bolj premika k vključevanju kompleksnejših, miselnih, družbenokritičnih in etičnih znanj ter veščin. Digitalna pismenost tako zajema nabor mnogih drugih pismenosti, kot so medijska, informacijska, vizualna, tehnološka, komunikacijska, socialna idr.

V nadaljevanju smo predstavili modele merjenja digitalne pismenosti. V okviru različnih projektov in pobud so pripravili modele merjenja in ocenjevanja digitalne pismenosti ter določili potrebna znanja in veščine za doseganje posameznih ravni. Osredotočili smo se na model opredelitve in merjenja digitalne pismenosti DCA, ki je bil osnova za pripravo vprašalnika in empirično analizo naše raziskave. Poleg modela D CA smo predstavili tudi model D I G C O M P, ki so ga razvili v okviru Digitalne agende EU. Model DIGCOMP je trenutno razvit le za področje izobraževanja, kjer so že izdelani opisniki posameznih področij in kompetenc.

Predstavili smo slovenski izobraževalni sistem in podrobneje prikazali srednješolsko izobraževanje. Osredotočili smo se na prenovo učnih načrtov gimnazijskih izobraževalnih programov in raziskali način vključevanja rabe IKT v prenovljenih učnih načrtih. Ugotovimo lahko, da je razvoj digitalne pismenost $v$ prenovljene učne načrte sicer vključen, vendar je to vključevanje zelo splošno opredeljeno. I K T je v večini učnih 
načrtov opredeljena kot orodje, s katerim si dijaki lahko pomagajo pri iskanju in zbiranju informacij, ali pa kot orodje za pisanje in predstavitve. Menimo, da bi sistematičnejša vključitev rabe I K T v smeri spremenjenih načinov in metod dela, ki jo I K T omogoča, lahko prinesla boljši končni učinek pri razvoju digitalne pismenosti dijakov.

Predpogoj za razvoj digitalne pismenosti dijakov je ustrezna opremljenost šol in usposobljenost učiteljev za rabo I K T, zato smo v nadaljevanju raziskali stanje $\mathrm{v}$ slovenskih šolah. Glede na rezultate mednarodnih raziskav in projekte, namenjene spodbujanju rabe I K T, ki so bili izvedeni v Sloveniji, lahko sklepamo, da so slovenske šole v povprečju tehnološko dobro opremljene. Velik korak naprej na področju usposabljanja učiteljev za rabo IKT je bil narejen s projektom E-šolstvo, izobraževanje učiteljev pa je ves čas mogoče v okviru stalnega strokovnega izpopolnjevanja.

$\mathrm{V}$ empiričnem delu raziskave smo izvedli raziskavo, $v$ katero smo vključili dijake 1. in 4. letnikov vseh gimnazijskih programov. Izvedli smo jo prek spletnega vprašalnika. Prejeli smo 490 popolnoma rešenih vprašalnikov, kar predstavlja 3,2-odstotni odziv. Med anketiranci je bilo $52 \%$ fantov in $70 \%$ dijakov splošnih gimnazij.

Raziskava je pokazala, da imajo skoraj vsi dijaki (95\%) doma namizni ali prenosni računalnik in $\mathrm{v}$ enakem deležu tudi pametni telefon, $\mathrm{s}$ katerim vsak dan dostopajo do interneta. Najpogostejša naprava za dostopanje do interneta je pametni telefon, na kar bi bilo smiselno misliti ob pripravi učnih gradiv, prilagojenih za mobilne naprave.

Med aktivnostmi, ki jih anketiranci najpogosteje izvajajo na internetu, sta komuniciranje, ki poteka prek pošiljanja sporočil, in iskanje informacij za osebno rabo ali v namene šolskih nalog. Preseneča podatek, da zelo malo anketirancev uporablja storitve shranjevanja datotek $\mathrm{v}$ oblaku ( $25 \%)$, komuniciranja prek videokonferenc $(6 \%)$ in pisanje spletnega dnevnika (3\%). Vse te storitve so dijakom na voljo za brezplačno rabo prek Arnesa - Akademske in raziskovalne mreže Slovenije. ${ }^{1}$

Čeprav mednarodne raziskave kažejo, da učenci svoje znanje s področja IK T večinoma pridobivajo $\mathrm{v}$ procesu izobraževanja, se je $\mathrm{v}$ naši raziskavi pokazalo, da kar $52 \%$ dijakov svoje znanje s področja rabe I K T pridobiva s samoučenjem prek različnih virov na internetu.

Razveseljiv je podatek, da $50 \%$ anketirancev I K T v šoli uporablja nekajkrat na teden, $21 \%$ pa celo vsak dan. Manj spodbuden pa je podatek,

${ }^{1}$ Glej https://www.arnes.si/storitve/storitve-za-posameznike/. 
da je $42 \%$ te uporabe omejene le na enega ali dva predmeta $v$ šoli, kar kaže na zelo neenakomerno vključevanje rabe IK T v poučevanje.

Digitalno pismenost smo merili po modelu DCA, ki preverja tri dimenzije, in sicer tehnološko, kognitivno in etično. Skupno so anketiranci v povprečju dosegli 62,4\% točk, kar je nizek rezultat. Več kot 75odstotno uspešnost, ki naj bi izkazovala ustrezno digitalno pismenost, je doseglo le 12,9\% dijakov. Pričakovano so bili dijaki najuspešnejši pri tehnološki dimenziji, kjer je bila uspešnost v povprečju 77,1\%. Sklepamo lahko, da so dijaki vešči reševanja osnovnih tehničnih problemov, uporabe osnovne programske opreme in da poznajo osnovne tehnološke koncepte. Precej slabša uspešnost se je pokazala pri kognitivni $(54,5 \%)$ in etični dimenziji $(55,6 \%)$. Iz teh rezultatov lahko sklepamo, da so dijaki manj vešči vrednotenja pridobljenih informacij, logičnih miselnih procesov in sestavljanja pridobljenih informacij v nova znanja. Dijaki tudi niso v dovolj visoki meri sposobni konstruktivnega sodelovanja, spoštovanja sebe in drugih pri komuniciranju na internetu. Težave imajo tudi pri razumevanju razsežnosti digitalnega razkoraka $\mathrm{v}$ družbi.

$\mathrm{Z}$ raziskavo smo preverjali štiri hipoteze, predstavljene $\mathrm{v}$ uvodu monografije. Posamezne spremenljivke smo združili v dimenzije po modelu D CA.

Pri prvi hipotezi smo predpostavljali, da obstaja statistično značilna povezanost med intenzivnostjo rabe I $\mathrm{K} T$ pri delu $\mathrm{v}$ šoli in doseženim rezultatom pri merjenju digitalne pismenosti. Pri preverjanju te hipoteze smo uporabili korelacijsko analizo, ki je pokazala pozitivno korelacijo, a ta ni bila statistično značilna. Hipoteze 1 tako ne moremo sprejeti in ne moremo trditi, da obstaja statistično značilna povezanost med intenzivnost rabe I K $\mathrm{T}$ in digitalno pismenostjo dijakov gimnazijskih programov.

Pri drugi hipotezi smo preverjali, ali dijaki strokovnih gimnazij pri posameznih dimenzijah digitalne pismenosti dosegajo boljši rezultat od dijakov splošnih gimnazij. Normalnost porazdelitve spremenljivke Vrsta gimnazijskega programa smo preverili s pomočjo KolmogorovSmirnovega in Shapiro-Wilkovega testa, statistično značilnost razlik pa s pomočjo neparametričnega Mann-Whitneyjevega testa. Analiza je pokazala, da v posameznih dimenzijah digitalne pismenosti glede na vrsto gimnazijskega programa ni statistično značilnih razlik, čeprav so dijaki strokovnih gimnazij pri vseh treh dimenzijah dosegli nekoliko boljše rezultate (preglednica 5.7). Hipoteze 2 tako nismo mogli potrditi. 
Pri hipotezi 3 smo preverjali, ali obstajajo statistično značilne razlike pri rezultatih merjenja digitalne pismenosti glede na spol. Primerjava doseženih rezultatov (preglednica 5.7) je sicer pokazala nekoliko boljše povprečne rezultate dijakov pri tehnološki in etični dimenziji, medtem ko je bil povprečni rezultat pri kognitivni dimenziji za dijake in dijakinje enak. Uporabili smo enako metodologijo preizkušanja kot pri hipotezi 2. Analiza je pokazala, da je spremenljivka za ženski spol normalno porazdeljena. Pri tehnološki in kognitivni dimenziji statističnih razlik glede na spol nismo zaznali. Pri etični dimenziji pa smo zaznali statistično značilno razliko, zato hipotezo 3 sprejemamo le delno. $\mathrm{Na}$ osnovi analize podatkov tako lahko sklepamo, da spol statistično značilno vpliva na rezultat etične dimenzije digitalne pismenosti.

Pri hipotezi 4 smo predvidevali, da obstajajo statistično značilne razlike rezultatov merjenja digitalne pismenosti glede na regijo, iz katere prihajajo anketiranci. Iz primerjave izračunih srednjih vrednosti dosežkov so anketiranci vzhodne Slovenije dosegli višje povprečne vrednosti pri vseh treh dimenzijah digitalne pismenosti. Spremenljivko Vrsta regije smo preverili s pomočjo Kolmogorov-Smirnovega in ShapiroWilkovega testa, statistično značilnost razlik pa s pomočjo neparametričnega Mann-Whitneyjevega testa. Analiza je pokazala, da v posameznih dimenzijah digitalne pismenosti po vrsti regije ni statistično značilnih razlik, zato hipoteze 4 nismo sprejeli.

V raziskavi smo se omejili na dijake 1. in 4. letnikov gimnazijskih programov, saj smo želeli raziskati, kaj se z digitalno pismenostjo dijakov dogaja v času šolanja na gimnaziji. Ugotavljanje učinkov je povezano s spremenjenim kurikulom gimnazijskih programov, pri katerem je bil +poudarek na vključevanju I K T. Kljub temu pa bi bilo v prihodnje podobno raziskavo smiselno opraviti tudi v ostalih letnikih gimnazijskih programov, prav tako pa tudi v ostalih srednješolskih programih. Prilagojen vprašalnik bi bil lahko primeren tudi za testiranje digitalne pismenosti učiteljev. Ustrezno prilagojena vprašanja bi bila lahko primerna tudi za vzpostavitev samoocenjevalnega spletnega vprašalnika, kjer bi lahko vsak posameznik preveril svojo raven digitalne pismenosti.

Rezultati raziskave so dobra osnova za razmislek o učinkovitosti spodbujanja digitalne pismenosti pri poučevanju. Rezultati te in tudi drugih mednarodnih raziskav kažejo, da v Sloveniji še vedno zaostajamo pri doseženi ravni digitalne pismenosti učencev in dijakov. 


\section{Literatura}

A C L R. 2000. Information Literacy Competency Standards for Higher Education. http://www.ala.org/acrl/standards/informationliteracycompetency

A C T I C. 2013. "Accreditation in IC T Skills.«http://acticweb.gencat.cat/web/ .content/o7_difusio/documents/arxius/actic_english_general _presentation_201301.pdf

Ala-Mutka, Kristi. 2011. Mapping Digital Competence: Towards a Conceptual Understanding. J R C Technical Notes 67075. Luxembourg: Publications Office of the European Union.

Ala-Mutka, Kirsti, Yves Punie, in Christine Redecker. 2008. Digital Competence for Lifelong Learning. J RC Technical Notes 48708. Luxembourg: Publications Office of the European Union.

Barr, Robert B., in John Tagg. 1995. "From Teaching to Learning: A New Paradigm for Undergraduate Education." Change 27 (6): 13-26.

Bélisle, Claire, in Eliana Rosado. 2006. »Analysing Digital Literacy Frameworks.« https://halshs.archives-ouvertes.fr/halshs-00137779/document

Bellanca, James, in Ron Brandt. 2010. 21st Century Skills: Rethinking How Students Learn. Bloomington, I N: Solution Tree.

Bowden, David. 2001. "Information and Digital Literacies: A Review of Concepts." Journal of Documentation 57 (2): 218-259.

Braden, Robert A. 2001. Visual Literacy: The Handbook of Research for Educational Communication and Technology. Bloomington, In: The Association for Eduacation Communications and Technology.

Bratuša, Slavica, in Nataša Kostanjevec, ur. 2014. "Sumativna evalvacija poteka in rezultatov projekta posodobitev gimnazijskih programov na šolski ravni.«http://publikacija.k56.si/splosno/7.\%2oEvalvacijsko\%2oporocilo .pdf

Brečko, Barbara Neža. 2009. „Cross-National Information and Communication Technology: Policies and Practices in Education."V Research in Educational Policy, ur. Tjeerd Plomp, 637-653. Charlotte, N C: I A P-Information Age.

Brečko, Barbara Neža, Vasja Vehovar in Vesna Dolničar. 2008. Informacijskokomunikacijska tehnologija pri poučevanju in učenju v slovenskih šolah. Ljubljana: Pedagoški inštitut. 
Buckingham, David. 2007. »Digital Media Literacies: Rethinking Media Education in the Age of the Internet."Research in Comparative and International Education 2 (1): 43-55.

Calvani, Antonio, Antonio Cartelli, Antonio Fini in Maria Ranieri. 2009. "Models and Instruments for Assessing Digital Competence at School. « Journal of E-learning and Knowledge Society 4 (3): 182-193.

Calvani, Antonio, Antonio Fini in Maria Ranieri. 2010. „Competéncia digital en educació primària i secundària: models teòrics, eines d'avaluació i investigació empírica." Anàlisi 40:157-171.

Calvani, Antonio, Antonio Fini, Maria Ranieri in Patrizia Picci. 2012. "Are Young Generations in Secondary School Digitally Competent? A Study on Italian Teenagers." Computers \& Education 58 (2): 797-807.

CEDE F O P. 2008. Terminology of European Education and Training Policy: A Selection of 100 Key Terms. Luxembourg: Office for Official Publications of the European Communities.

Černoša, Slavica. 2012. Razvoj sistema izobraževanja v Sloveniji v luči uresničevanja skupnih evropskih ciljev analiza uresničevanja ciljev "Izobraževanje in usposabljanje 2010«. Ljubljana: Pedagoški inštitut. http://www.pei.si/ UserFilesUpload/file/zalozba/ZnanstvenaPorocila/o1_12 _cernosa_razvoj_sistema.pdf

Eshet-Alkalai, Yoram. 2004. "Digital Literacy: A Conceptual Framework for Survival Skills in the Digital Era." Journal of Educational Multimedia and Hypermedia 13 (1): 93-107.

Eshet-Alkalai, Yoram, in Yair Amichai-Hamburger. 2004. "Experiments in Digital Literacy." CyberPsychology \& Behavior 7 (4): 421-429.

Eshet-Alkalai, Yoram, in Eran Chajut. 2010. "You Can Teach Old Dogs New Tricks: The Factors that Affect Changes over Time in Digital Literacy." Journal of Information Technology Education 9 (3): 173-181.

E-šolstvo. 2013. Utrip projekta e-šolstvo, št. 8. https://www.dlib.si/stream/URN :NBN:SI:DOC-9IF3YEDU/1c5163d9-2bo3-4b2b-9c6a-fb14408d5b89/PDF

E T S. 2002. »Digital Transformation: A Framework for IC T Literacy.« http:// www.ibertic.org/evaluacion/sites/default/files/biblioteca/32 _digitaltransformation.pdf

European Commision. 2014. »A Common European Digital Competence Framework for Citizens.« https://www.openeducationeuropa.eu/sites/ default/files/DIGCOMP\%2obrochure\%202014\%20.pdf

Ferrari, Anusca. 2012. Digital Competence in Practice: An Analysis of Frameworks. J R C Technical Reports. Luxembourg: Publications Office of the European Union.

Ferrari, A., Y. Punie in B. N. Brečko. 2013. DI G COM P: A Framework for Developing and Understanding Digital Competence in Europe. Luxembourg: Publications Office of the European Union. 
Flogie, Andrej, Špela Bergoč, Domen Kovačič, Kristijan Perčič, Igor Pesek, Magdalena Šverc in Maja Vičič-Krabonja. 2014. Informacijska tehnologija kot temelj vseživljenskega izobraževanja človeka 21. stoletja: vsebinski priročnik. Maribor: Zavod Antona Martina Slomška.

Fraillon, Julian, John Ainley, Wolfram Schulz, Tim Friedman in Eveline Gebhardt. 2014. Preparing for Life in a Digital Age: The IE A International Computer and Information Literacy Study. Dordrecht: Springer.

- 2015. ICILS 2013: Technical Report. Amsterdam: IE A Secretariat.

Gilster, Paul. 1997. Digital Literacy. New York: Wiley.

Gruden, Breda, Nives Kreuh, Andrej Flogie, Ingrid Možina Podbršček. 2013. „Utrip projekta e-šolstvo. VV Mednarodna konferenca SI Rikt 2013, ur. Nives Kreuh, Bernarda Trstenjak, Katarina Blagus, Maja Kosta in Anja Lenarčič, 10o. Ljubljana: Miška. https://skupnost.sio.si/sio_arhiv/sirikt/prispevki .sirikt.si/datoteke/sirikt_e_zbornik_2013.pdf

Hobbs, Renee. 2011. Digital and Media Literacy: Connecting Culture and Classroom. Thousand Oaks, c A: Corwin.

Howe, Neil, in William Strauss. 2009. Millennials Rising: The Next Great Generation. New York: Knopf Doubleday.

Irving, Christine. 2010. "Scottish Information Literacy Project Finishes at Glasgow Caledonian University.« Scottish Information Literacy Project, 7. april. http://www.caledonianblogs.net/information-literacy/

Jenkins, Henry. 2009. Confronting the Challenges of Participatory Culture: Media Education for the 21st Century. Cambridge, MA: The M I T Press.

Johnson, Larry, Adams Becker Samantha, Estrada Victoria, Freeman Alex, Kampylis Panagiotis, Punie Yves. 2014. The NMC Horizon Report Europe 2014: Schools Edition. Luxembourg: Publications Office of the European Union.

Junge, Kirsten, in Hari Hadjivassiliou. 2015. "What are the EU and Member States Doing to Address Digital Literacy? « eLearning Papers, no. 6: 3.

Katz, Irvin R. 2007. »Testing Information Literacy in Digital Environments: E T S's iSkills Assessment."Information Technology and Libraries 26 (3): 3.

Krapež, Alenka, Vladislav Rajkovič, Vladimir Batagelj in Rado Wechtersbach. 2001. »Razvoj predmeta računalništvo in informatika v osnovni in srednji šoli.«http://www.drustvo-informatika.si/fileadmin/dsi20o1/sekcija_e/ krapez_rajkovic_batagelj_wechtersbach.doc

Kreuh, Nives, in Barbara Neža Brečko. 2011. »Izhodišča standarda e-kompetentni učitelj, ravnatelj in računalnikar.«http://projekt.sio.si/wp-content /uploads/sites/8/2015/o1/E-solstvo_IZHODISCA_STANDARDA_web .pdf

Kreuh, Nives, Bredan Gruden, Amela Sambolič, Marija Mustar, Metka Košir, Borut Čampelj, Andrej Flogie, Janko Harej, Gregor Mohorčič, Ingrid Možina, Igor Razbornik, Magdalena Šverc in Bernarda Trstenjak. 
2012. »Pot do e-kompetentnosti«. E-šolstvo, št. 7. http://projekt.sio.si/wpcontent/uploads/sites/8/2015/o1/E-solstvo_pot_do_e-kompet_BILTEN _2012_final_web_pot_do_ekomp.pdf

Martin, Allan. 2006. "A European Framework for Digital Literacy.« Digital Kompetanse 2: 151-161.

Martin, Allan, in Jan Grudziecki. 20o6. „DigEuLit: Concepts and Tools for Digital Literacy Development. «Innovation in Teaching And Learning in Information and Computer Sciences 5 (4): 249-267.

National Council for Curriculum and Assessment. 2004. „Curriculum Assessment and ICT in the Irish Context: A Discussion Paper.« https://www .ncca.ie/media/1787/curriculum_assessment_and_ict_in_the_irish _context_a_discussion_paper.pdf

Newman, Tabetha. 2008. A Review of Digital Literacy in 0-16 Year Olds: Evidence, Developmental Models, and Recommendations. London: Becta.

Oblinger, Diana, in James L. Oblinger. 2005. Educating the Net Generation. Washington, DC: Educause.

OE CD. 2013. OE CD Communications Outlook 2013. Pariz: OE CD.

. 2015. Students, Computers and Learning: Making the Connection. Pariz: OECD.

. 2016. Trends Shaping Education 2016. Pariz: OE CD.

Pedagoški inštitut. 2014. "Mednarodna raziskava računalniške in informacijske pismenosti IC I L S 2013.«http://www.pei.si/UserFilesUpload/file/ raziskovalna_dejavnost/ICILS/ICILS_izrocki ZA novinarje.pdf

Pietrass, Manuela. 2007. "Digital Literacy Research from an International and Comparative Point of View."Research in Comparative and International Education 2 (1): 1-12.

Prensky, Marc. 2001. »Digital Natives, Digital Immigrants.« http://www .marcprensky.com/writing/Prensky - Digital Natives, Digital Immigrants - Part1.pdf

Rupnik Vec, Tanja, in Brigita Rupar. 2006. "Model celostne podpore Zavoda RS za šolstvo pri vpeljevanju sprememb in zagotavljanju kakovosti.« $\mathrm{V}$ Vpeljevanje sprememb v šole: konceptualni vidiki, 69-95. Ljubljana: Zavod Republike Slovenije za šolstvo.

— 2014. "Podpora šolskim razvojnim timom pri vpeljevanju sprememb - perspektiva ZRS š.«http://publikacija.k56.si/strokovnjaki/5. Dr. Tanja Rupnik Vec, Brigita Rupar. Podpora solskim razvojnim timom pri vpeljevanju sprememb - perspektiva ZRSS.pdf

Senge, Peter M., ur. 2012. Schools That Learn: A Fifth Discipline Fieldbook for Educators, Parents, and Everyone Who Cares about Education. New York: Crown Business. 
Sulčič, Viktorija. 2011. »Računalniška in internetna pismenost slovenske mladine."Uporabna informatika 18 (3): 147-158.

Statistični urad Republike Slovenije. 2014. Slovenske regije v številkah. Ljubljana: Statistični urad Republike Slovenije.

—. 2015a. »Statopis - statistični pregled Slovenije 2015.« http://www .stat.si/StatWeb/News/Index/5679

- 2015b. »V zahodni Sloveniji je imelo v prvem četrtletju 2015 dostop do interneta 83\% gospodinjstev, v vzhodni pa 73\%.« http://www.stat.si/ StatWeb/News/Index/5509

Taštanoska, Tanja, Nada Žgank in Domen Pal. 2014. Vzgoja in izobraževanje $v$ Republiki Sloveniji. Ljubljana: Ministrstvo za izobraževanje, znanost in šport.

Tondeur, Jo, Johan van Braak, Guoyuan Sang, Joke Voogt, Petra Fisser in Anne Ottenbreit-Leftwich. 2012. "Preparing Pre-Service Teachers to Integrate Technology in Education: A Synthesis of Qualitative Evidence.«Computers \& Education 59 (1): 134-144.

Tornero, José Manuel Pérez. 2004. „A New Model for Promoting Digital Literacy.« http://www.ictliteracy.info/rf.pdf/NewModelDigitalLiteracy2004 .pdf

U N E S C O. 2005. Information and Communication Technologies in Schools: A Handbook for Teachers Or How ICT Can Create New, Open Learning Environments. Pariz: U N E S CO.

- 2011. UNESCO ICT Competeny Framework for Teachers. 2. izd. Pariz: UNESCO.

Veen, Wim, in Ben Vrakking. 2006. Homo Zappiens: Growing Up in a Digital Age. London: Network Continuum Education.

Zavod Republike Slovenije za šolstvo. 2014. „Končno poročilo o uvajanju poskusa.«http://www.zrss.si/poskus-v-gimnaziji/files/KONCNO -POROCILO-marec2015-za-SSSI.pdf

Žakelj, Amalija. 2010. "Posodabljanje kurikularnega procesa v gimnazijski praksi.«http://publikacija.k56.si/strokovnjaki/7.\%2oProf.\%2odr .\%2oAmalija\%2oZakelj.\%2oPosodabljanje\%2okurikularnega\%2oprocesa \%20v\%2ogimnazijski\%2opraksi.docx 



\section{Priloge}

\section{Priloga 1: Opisniki področij digitalne kompetence okvira D I G C O M P}

\section{Informacije}

- Brskanje, dostopanje in filtriranje informacij: Posameznik je sposoben s pomočjo iskalnih orodij dostopati in iskati informacije na spletu, jih učinkovito zbrati, se premikati po iskalnih virih. Sposoben je ozavestiti svoje potrebe po informacijah in razviti lastno strategijo iskanja.

- Ocenjevanje informacij: Posameznik ob zbiranju pridobljene informacije kritično vrednoti in jih sistematično shranjuje.

- Shranjevanje in obdelava informacij: Posameznik pridobljene informacije ustrezno obdela in organizirano shranjuje na način, ki omogoča kasnejši priklic.

Komunikacija

- Sodelovanje s pomočjo tehnologije: Posameznik razume načine sodobnega komuniciranja, pozna različne oblike in strategije komuniciranja, uporablja različne digitalne naprave in aplikacije, prilagaja načine komuniciranja ciljni skupini poslušalcev.

- Izmenjava informacij in vsebin: Posameznik je pripravljen in zna pridobljeno znanje, vsebine in vire posredovati drugim, pozna načine citiranja in gradnje novih znanj iz nabora pridobljenih informacij.

- Udejstvovanje skozi digitalno državljanstvo: Posameznik se zaveda potenciala tehnologije za samorazvoj, aktivno državljansko participacijo in udejstvuje pri raznolikih spletnih aktivnostih.

- Sodelovanje s pomočjo digitalnih kanalov: Posameznik zna uporabiti tehnologijo za potrebe timskega dela, sodelovanja $z$ drugimi in sogradnjo znanja, virov in vsebin.

- Netetika: Posameznik se zaveda možnih spletnih nevarnosti, razvija strategije za odkrivanje neprimernega vedenja, zaveda se vidikov kulturne raznolikosti.

- Upravljanje digitalne identitete: Posameznik je sposoben ustvariti, upravljati in zaščititi svojo digitalno identiteto, zaščititi ugled sebe in drugih in upravljati podatke več uporabniških računov. 
Ustvarjanje vsebin

- Razvijanje vsebin: Posameznik se je sposoben izražati s pomočjo digitalnih medijev in tehnologij, ustvarjati lastne vsebine v različnih formatih in zrediti vsebine, ki jih je ustvaril nekdo drug.

- Integriranje in ponovno izdelovanje: Posameznik je sposoben ustvariti nova znanja in vsebine prek spreminjanja, združevanja in izboljšanja že obstoječih virov.

- Avtorske pravice in licence: Posameznik razume in uporablja licence, ki varujejo informacije in vsebine.

- Programiranje: Posameznik razume osnovne principe programiranja in zna nastaviti ter spreminjati programe, aplikacije in naprave.

Varnost

- Varovanje naprav: Posameznik pozna varnostne in preventivne ukrepe ter zna zaščititi lastne naprave in razumeti spletna tveganja.

- Varovanje osebnih podatkov: Posameznik se zna zaščititi pred spletnimi prevarami, ustrahovanji in grožnjami, obenem varuje osebne podatke in spoštuje zasebnost drugih.

- Varovanje zdravja: Posameznik se zaveda nevarnosti in tveganj, povezanih z rabo tehnologije.

- Varovanje okolja: Posameznik pozna možen vpliv tehnologije na varovanje okolja.

Reševanje problemov

- Reševanje tehničnih problemov: Posameznik s pomočjo digitalnih sredstev opredeli težave in odpravlja osnovne ter kompleksnejše probleme.

- Identificiranje potreb in tehničnih možnosti: Posameznik zna kritično oceniti možne rešitve problemov in načrtovati potrebe po digitalnih orodjih, virih in razvoju kompetenc.

- Inoviranje in kreativna raba tehnologije: Posameznik s pomočjo digitalnih orodij aktivno in inovativno ustvarja, sodeluje $z$ drugimi in rešuje konceptualne probleme.

- Identificiranje razkoraka pri digitalnih kompetencah: Posameznik je sposoben oceniti svoje potrebe po nadgrajevanju kompetenc in pri tem podpira tudi druge.

\section{Primer zapisa kompetence Sodelovanje s pomočjo tehnologije}

Vidik 1 - ime področja: Komuniciranje

Vidik 2 - Ime kompetence in opis

2.1 Sodelovanje s pomočjo tehnologije

- Sodelovati s pomočjo različnih digitalnih naprav in aplikacij

- Razumeti razširjanje, prikazovanje in upravljanje digitalnih komunikacij 
- Razumeti ustrezne načine komuniciranja s pomočjo digitalnih pripomočkov

- Odzivati se na različne komunikacijske oblike

- Prilagajati načine komuniciranja in strategije specifični publiki.

\section{Vidik 3 - Nivoji zmožnosti}

Temeljni

- Znam sodelovati z drugimi uporabljajoč osnovne funkcije komunikacijskih orodij (npr. mobitel, vo I P, klepet ali e-pošta)

Vmesni

- Znam uporabljati več različnih digitalnih orodij za interakcijo z drugimi, ki uporabljajo naprednejše funkcije komunikacijskih orodij (npr. mobitel, Vo I P, klepet ali e-pošta).

Napredni

- Uporabljam široko paleto orodij za online komunikacijo (e-pošto, klepetalnico, takojšnje sporočanje, bloge, mikrobloge s N s).

- Znam sprejeti digitalne oblike in načine komuniciranja, ki najbolj ustrezajo namenu.

- Znam prilagoditi obliko in načine komuniciranja občinstvu.

- Lahko upravljam z različnimi načini komuniciranja.

\section{Vidik 4 - Primeri}

Znanja

- Zaveda se različnih digitalnih komunikacijskih sredstev (e-pošta, klepetalnica, VoIP, videokonference, SM S).

- Ve, kako se sporočila in e-pošta shranjujejo ter prikažejo.

- Pozna delovanje različnih programskih paketov komunikacijske opreme.

- Pozna prednosti in omejitve različnih sredstev za komuniciranje in glede na kontekst (situacijo) izbere najustreznejše.

Veščine

- Zmožen je poslati e-pošto, napisati prispevek v blogu, s Ms.

- Sposoben je najti vrstnike in stopiti v stik z njimi.

- Sposoben je urediti podatke za prikaz in pošiljanje z različnimi sredstvni ali načini (od pošiljanja e-pošte do priprave predstavitve s prosojnicami).

- Oceni svoje občinstvo in mu prilagodi način komunikacije.

- Sposoben je filtrirati sporočila, ki jih prejme (npr. razvrstiti e-pošto, odločiti se, komu slediti na mikroblogerskih družbenih straneh).

Prepričanja, stališča in odnosi

- Samozavestno in sproščeno komunicira in se izraža preko digitalnih medijev. 
- Zaveda se, kateri kodeks obnašanja ustreza določeni situaciji.

- Zaveda se tveganj, povezanih s spletno komunikacijo z neznanimi ljudmi.

- Aktivno sodeluje v spletni komunikaciji.

- Pripravljen je izbrati najustreznejše komunikacijsko sredstvo glede na namen.

Vidik 5 - Učenje

Temeljni nivo

- Uporabljam klepetalnico ali forum razprav za komunikacijo z drugimi učenci pri pouku.

Vmesni nivo

- Uporabljam klepet za komunikacijo z drugimi učenci, če je nujno, sodelujem tudi v skupnem klepetu ali ga moderiram. Po potrebi uporabljam Vo IP za pogovor $z$ drugimi učenci.

Napredni nivo

- Uporabljam več komunikacijskih orodij za pogovor z drugimi učenci (mobilni telefon, Vo IP, klepet ali e-mail).

- Uporabljam različne funkcije VoIPa pri delu na projektu z drugimi učenci: znam uporabiti funkcijo deljenja zaslona, znam posneti pogovor in ga predvajati.

- Vem, katero komunikacijsko orodje izbrati glede na namen in velikost občinstva.

\section{Priloga 2: Ravni znanja in veščin modela merjenja ICILS 2013}

Raven 4 ( ad 661 točk)

- izbira najustreznejših informacij za namene komuniciranja z drugimi uporabniki

- vrednotenje informacij, temelječih na izbranih kriterijih

- vrednotenje zanesljivosti informacij glede na vsebino in vir

- ustvarjanje novih informacij, temelječih na potrebah ciljne skupine in $\mathrm{z}$ upoštevanjem načina komunikacije

- uporaba ustrezne programske opreme za klasifikacijo in predstavitev informacij

- zavedanje o spoštovanju avtorskih pravic informacij na internetu

\section{Raven 3 (med 577 in 661 točk)}

- samostojno delo z računalnikom pri zbiranju in urejanju informacij

- izbira najprimernejših informacijskih virov za specifične potrebe, pridobivanje informacij za iskanje odgovorov na konkretna vprašanja 
- sposobnost sledenja navodilom za uporabo programske opreme za urejanje, dodajanje in preoblikovanje informacij

- določanje verodostojnosti informacij, na katere lahko vplivajo različni motivi ustvarjalca informacije

\section{Raven 2 (med 492 in 576 točk)}

- uporaba računalnika za dokončanje osnovnih poizvedb po informacijah in opravljanje osnovnih nalog, povezanih z urejanjem informacij

- zmožnost enostavnega urejanja in dodajanja informacij k obstoječi vsebini

- ustvarjanje osnovnih informacij z upoštevanjem pravil oblikovanja

- zavedanje o načinih zavarovanja lastnih informacij in nevarnostih javnega izpostavljanja osebnih podatkov

\section{Raven 1 (med 407 in 491 točk)}

- funkcionalno znanje o računalniku kot orodju in osnovno razumevanje o možnostih uporabe računalnika s strani več oseb

- poznavanje osnovnih načinov komuniciranja in dodajanja vsebine k obstoječim informacijam

- osnovno poznavanje postavitev elektronskih dokumentov

\section{Priloga 3: Anketni vprašalnik}

Q1 - Izberite vrsto gimnazijskega programa

- Splošni gimnazijski program

- Strokovni gimnazijski program

Q2 - Izberite letnik, v katerem se šolate

- letnik

- 4. letnik

XSPOL - Spol:

- Moški

- Ženski

Q3 - Izberite regijo šole, ki jo obiskujete

- Pomurska regija

- Podravska regija

- Koroška regija

- Savinjska regija

- Zasavska regija

- Posavska regija

- Jugovzhodna Slovenija 
- Osrednjeslovenska regija

- Gorenjska regija

- Primorsko-notranjska regija

- Goriška regija

- Obalno-kraška regija

Q4 - Katere naprave uporabljate?

- Stacionarni in/ali prenosni računalnik

- Mobilni telefon brez dostopa do interneta

- Pametni telefon z dostopom do interneta

- Tablica (iPad, Galaxy Tab ...)

Q5 - Kako pogosto doma dostopate do interneta?

- Vsak dan

- Nekajkrat tedensko

- Nekajkrat mesečno

- Nekajkrat letno

- Doma nimam dostopa do interneta

- Drugo:

Q6 - Na kakšen način najpogosteje dostopate do interneta?

- Računalnik (stacionarni ali prenosni)

- Pametni telefon

- Tablica

- Vse zgoraj omenjene naprave

- Drugo:

Q7 - Do interneta največkrat dostopate:

- Doma

- V šoli

- Na javnih prostorih z dostopom do interneta

- Drugo:

Q8 - Za kakšne namene najpogosteje uporabljate internet (možnih je več odgovorov)?

- Iskanje informacij za osebno rabo in/ali šolo (novice, vremenska napoved, članki, študij ...)

- Pošiljanje in prejemanje e-pošte

- Komunikacija s prijatelji prek sporočil (Skype, Whatsapp, Messenger, Google Talk, Snapchat ...)

- Prenos aplikacij in/ali multimedijskih vsebin

- Poslušanje glasbe in gledanje filmov 
- Dostop in uporaba socialnih omrežij (F B, T W, Google+, Linkedin ...)

- Upravljanje svojega bančnega računa

- Spletno nakupovanje

- Uporaba storitev v oblaku (Dropbox, Google Drive ...)

- Uporaba storitev e-države (plačevanje davkov, oddaja napovedi dohodnine ...)

- Komuniciranje s pomočjo videokonferenc

- Sodelovanje v forumih

- Sodelovanje s sošolci prek uporabe deljenih dokumentov (Google Drive, Sites, Scoop.it ...)

- Nalaganje in deljenje svojih multimedijskih vsebin

- Pisanje lastnega dnevnika (bloga)

- Drugo:

Q9 - Kje ste pridobili največ znanja o rabi IKT (informacijsko komunikacijska tehnologija)?

- V procesu šolanja

- Samoučenje s pomočjo virov, dostopnih na spletu

- Prek udeležbe na tečajih

- Moje znanje o I K T je šibko

- Drugo:

Q10 - Kako pogosto uporabljate I K T pri delu v šoli?

- Vsak dan

- Nekajkrat tedensko

- Nekajkrat mesečno

- Nekajkrat letno

- Drugo:

Q11 - Pri koliko predmetih v šoli uporabljate I K T?

- Pri vseh

- Pri polovici

- Pri četrini

- Pri enem ali dveh predmetih

- Pri nobenem predmetu

T1 - Pri delu z računalnikom opazite, da deluje zelo počasi. Kaj bi lahko bili vzroki za tako delovanje (označite 3 odgovore)?

- Odpoved napajanja računalnika

- Okuženost računalnika z virusom 
- Slabo hlajenje sistema

- Težave z zagonom računalnika

- Preveč odprtih programov istočasno

- Preveč nameščenih programov na računalniku

- Nenadne spremembe v napajanju računalnika

- Drugo:

T 2 - Pri brskanju po spletu ste v brskalnik vpisali naslov spletne strani in dobili naslednji odgovor: Napaka 404: Zahtevane strani ni moč najti na strežniku. Kako lahko razlagate to (označite 3 odgovore)?

- Naslov spletne strani (U R L) je napačen

- Na računalniku nimamo naloženega ustreznega programa

- Internetna povezava je prekinjena

- Gre za napako pri strežniku, ki gosti spletno stran

- Računalnik nima dovolj delovnega spomina (RAM)

T3 - Na tiskalniku želite natisniti dokument, vendar pri zahtevi po tiskanju tiskalnik ne natisne dokumenta. Kaj boste preverili, če želite rešiti ta problem (označite 3 odgovore)?

- Ali je nameščen gonilnik za tiskalnik?

- Ali je povezava $\mathrm{z}$ internetom vzpostavljena?

- Ali deluje avdio sistem?

- Ali na tiskalniku gori lučka, ki označuje napako pri delovanju?

- Ali je računalnik priključen na napajanje?

- Ali je tistalnik prižgan?

T 4 - Ikone (majhne sličice) predstavljajo nekaj najbolj pogostih naprav, map, programske opreme, dokumentov, operacij in posebnih operacij. Ikone so lahko povezane s posebnim programom ali operacijskim sistemom, a pri tej nalogi je potrebno prepoznati le, kaj predstavljajo.
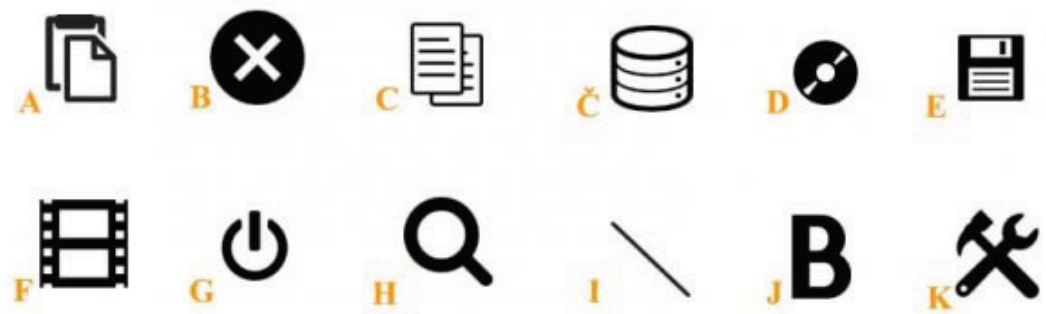
Vključi/Izključi

Nadzorna plošča

Shrani

Napaka

Črta

CD/DVD

Krepko

Kopiraj

Baza podatkov

Prilepi

Video datoteka

Povečaj $\begin{array}{lllllllllllll}\text { A } & B & C & \check{C} & D & \text { E } & \text { F } & \text { G } & \text { H } & \text { I } & \text { J } & \text { K }\end{array}$

$\bigcirc \bigcirc \bigcirc \bigcirc \bigcirc \bigcirc \bigcirc \bigcirc \bigcirc \bigcirc \bigcirc \bigcirc$

$\circ \bigcirc \bigcirc \bigcirc \bigcirc \bigcirc \bigcirc \bigcirc \bigcirc \bigcirc \bigcirc \bigcirc$

$0 \bigcirc \bigcirc \bigcirc \bigcirc \bigcirc \bigcirc \bigcirc \bigcirc \bigcirc \bigcirc 0$

$\circ \bigcirc \bigcirc \circ \bigcirc \bigcirc \bigcirc \bigcirc \circ \bigcirc \bigcirc 0$

$\bigcirc \bigcirc \bigcirc \bigcirc \bigcirc \bigcirc \bigcirc \bigcirc \bigcirc \bigcirc \bigcirc 0$

$\bigcirc \bigcirc \bigcirc \bigcirc \bigcirc \bigcirc \bigcirc \bigcirc \bigcirc \bigcirc \bigcirc 0$

$\circ \bigcirc \bigcirc \circ \bigcirc \bigcirc \bigcirc \bigcirc \bigcirc \bigcirc \bigcirc 0$

$\bigcirc \bigcirc \bigcirc \bigcirc \bigcirc \bigcirc \bigcirc \bigcirc \bigcirc \bigcirc \bigcirc 0$

$\circ \bigcirc \bigcirc \bigcirc \circ \bigcirc \bigcirc \bigcirc \bigcirc \bigcirc \bigcirc 0$

$\circ \bigcirc \bigcirc \bigcirc \bigcirc \bigcirc \bigcirc \bigcirc \bigcirc \bigcirc \bigcirc 0$

$\circ \bigcirc \bigcirc \bigcirc \bigcirc \bigcirc \bigcirc \bigcirc \bigcirc \bigcirc \bigcirc 0$

$\bigcirc \bigcirc \bigcirc \bigcirc \bigcirc \bigcirc \bigcirc \bigcirc \bigcirc \bigcirc \bigcirc \bigcirc$

T5 - Spodaj prikazane slike označujejo orodne vrstice različnih programov. Povežite jih $z$ ustreznim programom.

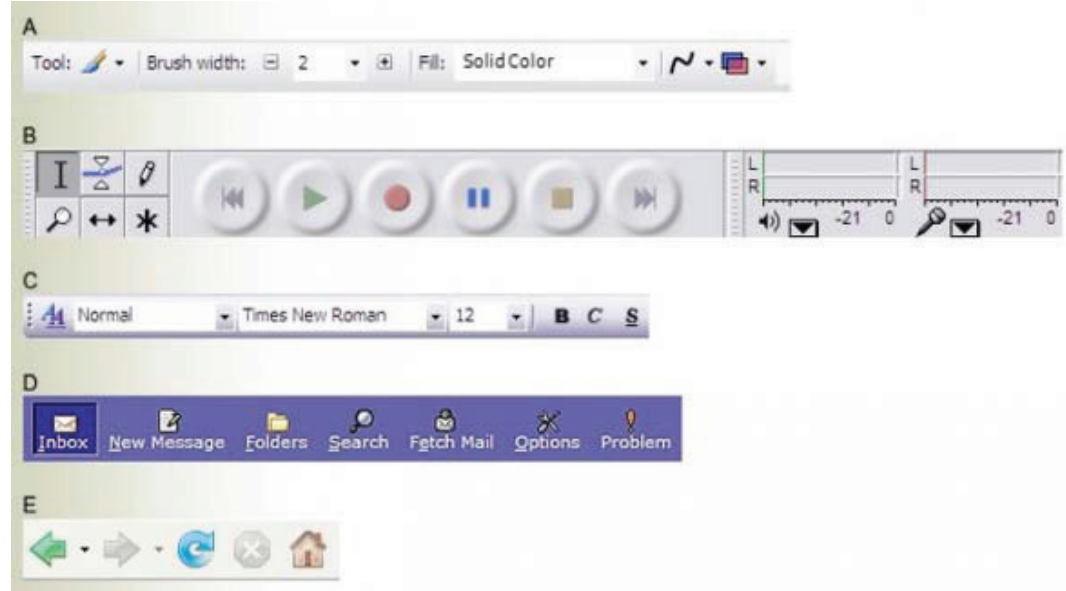

$\begin{array}{llllll} & \text { A } & \text { B } & C & D & \text { E } \\ \text { Urejanje besedil } & \bigcirc & \bigcirc & \bigcirc & \bigcirc & \bigcirc \\ \text { Urejanje grafike } & \bigcirc & \bigcirc & \bigcirc & \bigcirc & \bigcirc \\ \text { E-pošta } & \bigcirc & \bigcirc & \bigcirc & \bigcirc & \bigcirc \\ \text { Brskalnik } & \bigcirc & \bigcirc & \bigcirc & \bigcirc & \bigcirc\end{array}$

Urejanje avdio datotek $\bigcirc \bigcirc \bigcirc \bigcirc \bigcirc$

T6 - Skupina dijakov želi skupno ustvariti in napisati projektno nalogo. Pri tem mora s pisanjem sodelovati vsak član skupine. Kaj je najboljša tehnična rešitev take naloge? 
- Prenašanje ene natisnene kopije dokumenta med vsakega člana po vsaki spremembi

- Uporaba e-pošte za pošiljanje sprememb med pisanjem dokumenta vsakemu dijaku

- Uporaba spletnega urejevalnika besedil in deljenje besedila med dijake

- Deljenje natisnjenga besedila med vse člane skupine

T7 - V omari ste odkrili papirno verzijo družinskega albuma. Veste, da je iz nje moč narediti digitalni album, ki je opremljen tudi z glasbo in/ali videoposnetki. Katera trditev je pravilna?

- Uporabil bom programsko opremo za upravljanje e-pošte in grafike.

- Uporabil bom čitalec, programsko opremo za digitalizacijo in upravljanje multimedijskih vsebin.

- Uporabil bom hitro internetno povezavo in dober iskalnik.

- To lahko opravi le strokovnjak s specializirano programsko opremo.

K1 - Pred približno 25.00o leti, v času paleolitske dobe, so se pojavili prvi znaki figurativne umetnosti. Ti izrazi so bili naravoslovno usmerjeni-prikazovali so podobe vidnega sveta prazgodovinskega človeka. V seznamu izberite možnost, katere ključne besede najboljše opišejo zgornje besedilo:

- Znaki, Paleolitik, prazgodovinski človek

- Umetnost, Paleolitik, naravoslovje

- Umetnost, Paleolitik, orodja

- Figurativna umetnost, slike iz votlin, skulpture

- Risanje, paleolitik, svet

K2 - Ko se je Dioklecian leta 305 odrekel oblasti in upokojil, je Konstantin Veliki premagal Maksimilijana, zadnjega svojih nasprotnikov. Zmagal je v bitki pri Milvijskem mostu, leta 312, in postal rimski cesar. Vzpon Konstantina je $\mathrm{v}$ svetovni zgodovini pomemben zato, ker je bil prvi cesar, ki je sprejel krščanstvo in po vsem cesarstvu razglasil versko svobodo. Kakšen bi bil najustreznejši naslov zgornjega odstavka?

- Po Dioklecianovi upokojitvi je bilo mnogo vojn

- Konstantinova vojska je premagala Maksimilijanove vojščake

- Konstantin je zmagal v bitki pri Milivijskem mostu leta 312

- Konstantinova doba sovpada z rojstvom krščanskega imperija

K3 - Gospodar prstanov je fantazijski roman, ki ga je napisal angleški pisatelj in jezikoslovec J. R. R. Tolkien. Pisatelj je roman izdal v treh delih, in sicer: Bratovščina prstana, Stolpa in Kraljeva vrnitev. Zgornje besedilo povežite $\mathrm{v}$ stavek, tako, da upoštevate črke v okvirčkih ali pri pušcicah, kot je prikazano na naslednji strani. 
E

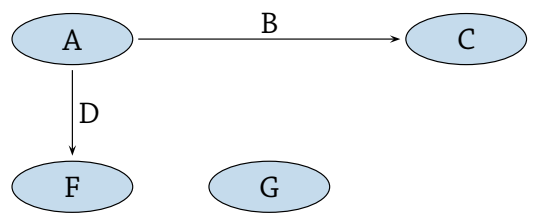

$\begin{array}{lllllll}\text { A } & \text { B } & \text { C } & \text { D } & \text { E } & \text { F } & \text { G }\end{array}$

Gospodar prstanov

J. R. R. Tolkien

je napisal

je izdal

Bratovščina prstana

Stolpa

Kraljeva vrnitev

$\begin{array}{lllllll}\bigcirc & \bigcirc & \bigcirc & \bigcirc & \bigcirc & \bigcirc & \bigcirc \\ \bigcirc & \bigcirc & \bigcirc & \bigcirc & \bigcirc & \bigcirc & \bigcirc \\ \bigcirc & \bigcirc & \bigcirc & \bigcirc & \bigcirc & \bigcirc & \bigcirc \\ \bigcirc & \bigcirc & \bigcirc & \bigcirc & \bigcirc & \bigcirc & \bigcirc \\ \bigcirc & \bigcirc & \bigcirc & \bigcirc & \bigcirc & \bigcirc & \bigcirc \\ \bigcirc & \bigcirc & \bigcirc & \bigcirc & \bigcirc & \bigcirc & \bigcirc \\ \bigcirc & \bigcirc & \bigcirc & \bigcirc & \bigcirc & \bigcirc & \bigcirc\end{array}$

K4 - Spodnjo tabelo uredite po abecedi glede na ime kontinenta.

\begin{tabular}{llll}
\hline Vrstica & Država & Kontinent & Jezik \\
\hline $\mathbf{1}$ & Italija & Evropa & Italijanščina \\
$\mathbf{2}$ & Z D A & Amerika & Angleščina \\
3 & Japonska & Azija & Japonščina \\
\hline
\end{tabular}

Po ureditvi bo ...

Vrstica 1 bo postala vrstica

$\begin{array}{lllll}1 & 2 & 3 & 4 & 5\end{array}$

Vrstica 2 bo postala vrstica

$\bigcirc \bigcirc \bigcirc \bigcirc \bigcirc$

Vrstica 3 bo postala vrstica

K5 - V spodnji tabeli je prikazan izkaz uspeha poslovanja podjetja DP, d. o. o. Kolikšno bi bilo stanje razpoložljivih sredstev podjetja ob koncu januarja, če v podjetju ne bi imeli nobenih stroškov?

\begin{tabular}{lrrr}
\hline A & B & C & D \\
\hline & & & Stanje ob koncu leta \\
\hline \hline Mesec & & & 800 \\
\hline Januar & Prihodki & Stroški & Stanje ob koncu \\
Februar & & & meseca \\
Marec & 100 & 50 & 90 \\
April & 1200 & 200 & 1700 \\
\hline
\end{tabular}


K6 - V spodnji tabeli je prikazano vaše finančno stanje. Kolikšni so bila vaši stroški v mesecu marcu?

\begin{tabular}{lrrr}
\hline A & B & C & D \\
\hline & & Stanje ob koncu leta \\
\hline \hline Mesec & & Stroški & Stanje ob koncu \\
& Prihodki & & meseca \\
\hline Januar & & 50 & 90 \\
Februar & 100 & 120 & 170 \\
Marec & 200 & & 240 \\
\hline
\end{tabular}

K 7 - V spodnjem grafikonu je prikazana struktura prebivalcev Indije po veri, ki ji pripadajo.

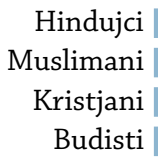

Izberite dve trditvi, ki sta pravilni:

- Kristjani so večina populacije.

- Budisti so najmanjša manjšina.

- Muslimani so večina populacije.

- Kristjanov je več kot muslimanov.

K 8 - V medijih se to pomlad množično pojavljajo novice o možnosti epidemije gripe. S ciljem informiranosti o ukrepih za preprečitev obolelosti se odpravite raziskovat na splet in pri iskanju dobite naslednje rezultate:

Začetek cepljenja proti gripi: S cepljenjem nad letošnjo ... www.nijz.si/.../zacetek-cepljenja-proti-gripi-s-cepljenjem-nad-letosnjo-gr... . 5. okt. 2015 - 10. 2015. Ta teden se začenja cepljenje proti sezonski gripi. Nacionalni inšttitut za javno zdravje (NIJZ) cepljenje priporoča vsem prebivalcem, ...

\section{GRIPA News}

www.gripa.org/press-room.asp $~-$ Prevedi to stran

GRIPA News. Stay informed. September, 2015. Modern Healthcare: What Medicare's value-based insurance test could mean for commercial plans.

Geographic Map Gripa, all Car repair in the Gripa addresses ... mapszoom.com/maps.php?town=Gripa\&radius...car... - Prevedi to stran Geographic Map Gripa detailed satellite topographical map of 2015, all Car repair in the Gripa phone numbers and addresses of objects - an online directory, ... 


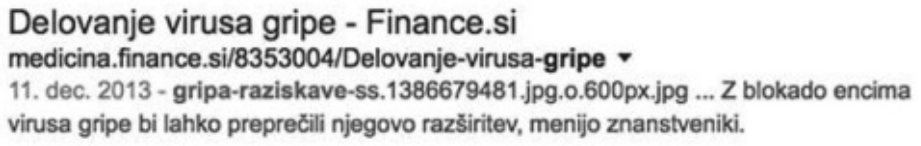

Katera od ponujenih možnosti vam bo ponudila najaktualnejše informacije?

- Začetek cepljenja | Inštitut za javno zdravje

- GRIPA news

- Geographic Map gripa

- Delovanje virusa gripe | Finance

- Gripa | Wikipedija

K 9 - Ko uporabljate spletni iskalnik, vam le-ta ob vnosu poljubne ključne besede vrne niz zadetkov. Povezave, ki so na vrhu niza zadetkov, imajo skupno značilnost. Izberi:

- Vsebujejo najuporabnejše informacije vašega iskanja.

- Vsebujejo največjo količino informacij vašega iskanja.

- Prikažejo najkakovostnejše zadetke in ustrezne informacije vašega iskanja.

- Najbolj ustrezajo kriterijem spletnega iskalnika v povezavi z vašim iskanjem.

K10 - Novica, ki opisuje napad dveh mladoletnikov na starejšega človeka, je objavljena v različnih medijih. Izberi naslov, kjer je avtor prispevka podal tudi svojo čustveno reakcijo ob tem napadu.

- Dva mladoletnika na cesti oropala starejšega moža

- Starejši človek je bil oropan s strani dveh mladoletnih oseb

- Nasilje na ulicah narašča: še en napad na starejšo osebo

- Še ena starejša oseba napadena na cesti s strani mladoletnikov

- Starejši človek napaden korak pred svojim domom

E 1 - Starši želijo prek spletne strani naročiti zadnji model pametnega telefona. Kaj menite ob tem (izberite dva odgovora)?

- Nakup prek spleta je možen. Najbolj poznane spletne trgovine omogočajo ocenjevanje kakovosti storitve prodajalca in prebiranje ocen izdelka s strani kupcev.

- Nakup prek spleta je možen, vendar obstaja možnost goljufij s strani prodajalcev in težav s plačili. 
- Nakup prek spleta je možen in je enakovreden nakupu v tradicionalnih trgovinah. Če z nakupom niste zadovoljni, lahko izdelek vrnete.

- Nakup dražjih izdelkov prek spleta ni možen.

E 2 - Med pogovorom s prijatelji na spletu se skupini pridruži oseba @Mister, ki vas začne žaliti (npr. »neumnež, nič ne razumeš ...«) in pošiljati še druge negativne komentarje. Kaj storite ob taki priložnosti?

- Pozoveš vse svoje prijatelje, da pošljejo žaljive komentarje osebi @Mister.

- Pošlješ osebi @Mister prek zasebnega sporočila žaljivo sporočilo.

- Napišeš sporočilo v slogu »Kaj te muči?« Če se žalitve nadaljujejo, zapustiš klepetalnico.

- Takoj se odzoveš z »Ti si pa res super neumen« in nato nadaljuješ s podobnimi komentarji.

E 3 - Novičarski seznam omogoča posameznikom, ki so vanj vključeni oziroma prijavljeni, sprejemanje in pošiljanje e-poštnih sporočil vsem naročnikom. Prijavili ste se na novičarsko listo o športu. Izberite tri možnosti objav, ki na to listo ne sodijo:

- Mojca, po tekmi se dobimo v lokalu Zvezdica.

- Za vse interesente: posnetek tekme bo jutri objavljen na spletni strani.

- Naložen video s posnetkom končnice teka na $400 \mathrm{~m}$.

- Moj brat je prekinil zvezo z Natašo.

- Obvestilo: finale košarkarske tekme bo naslednjo nedeljo.

- Jan, si zmagal včeraj?

E 4-V šoli morate napisati esej o znanosti. Med brskanjem po spletu na spletni strani www.climate.org najdete zanimive informacije. Med njimi je tudi stavek znanstvenika Johna Doa: "Zaradi segrevanja Zemljine povprečne temperature se bo morska gladina v naslednjih nekaj letih dvignila za $20 \mathrm{~cm}$."Kako boste to povzeli v svojem eseju?

- Citirali boste avtorja, naslov spletne strani in datum ogleda.

- Citirali boste z dodatkom (dosegljivo na spletu).

- Zapisal bom kot citat brez posebnih nadaljnjih informcij.

- Citiral bom s pripisom - avtor: John Doe.

E 5 - Bojan se je na svojem spletnem blogu ponorčeval iz Mojčinega fizičnega izgleda in ob tem povabil še svoje prijatelje h komentarju bloga. Kaj menite o tem?

- Gre za šalo. S tem ni nič narobe.

- Če gre za mladino, je to normalno početje.

- Sicer se ne strinjate z Bojanom, a vseeno zapišete nekaj na njegov blog.

- To početje je popolnoma nesprejemljivo. 
E 6 - Vaša šola v projektu sodeluje s šolo v Dakarju, Senegal. V okviru projekta se učence spodbuja, da prek izmenjave e-poštnih sporočil čim več komunicirajo s kolegi iz Senegala, vendar so naprošeni, da v e-poštna sporočila ne pripenjajo avdio- ali videovsebin. Kakšno je vaše mnenje v zvezi s tem priporočilom?

- $\mathrm{Z}$ njim se ne strinjam in ne razumem, zakaj ne bi smel pripenjati takih vsebin.

- To priporočilo ni pomembno in se lahko ignorira.

- Je pravilno in popolnoma razumljivo.

- Ne razumem tega priporočila, a ga bom upošteval.

E 7 - V Sloveniji ima več kot $90 \%$ gospodinjstev dostop do interneta.

- Da

- $\mathrm{Ne}$

E 8 - Manj kot 20\% mladostnikov (v svetovnem merilu), starih od 11-15 let, nima dostopa do interneta.

- Da

- $\mathrm{Ne}$

E 9 - Nepismeni ljudje lahko brez težav uporabljajo internet, kajti na spletnih straneh se pojavlja vedno več slik, avdio- in videoposnetkov.

- $\mathrm{Da}$

- $\mathrm{Ne}$

E 10 - Več kot $80 \%$ spletnih strani je zapisanih v angleščini.

- $\mathrm{Da}$

- $\mathrm{Ne}$

E 11 - Več kot $90 \%$ mladostnikov (11-14 let) v Sloveniji ima dostop do interneta od doma.

- $\mathrm{Da}$

- $\mathrm{Ne}$

E 12 - V Sloveniji ima manj kot $75 \%$ gospodinjstev doma T V sprejemnik.

- $\mathrm{Da}$

- $\mathrm{Ne}$

E 13 - V Sloveniji manj kot 30 \% uporabnikov uporablja pametne telefone z dostopom do interneta.

- $\mathrm{Da}$

- $\mathrm{Ne}$ 


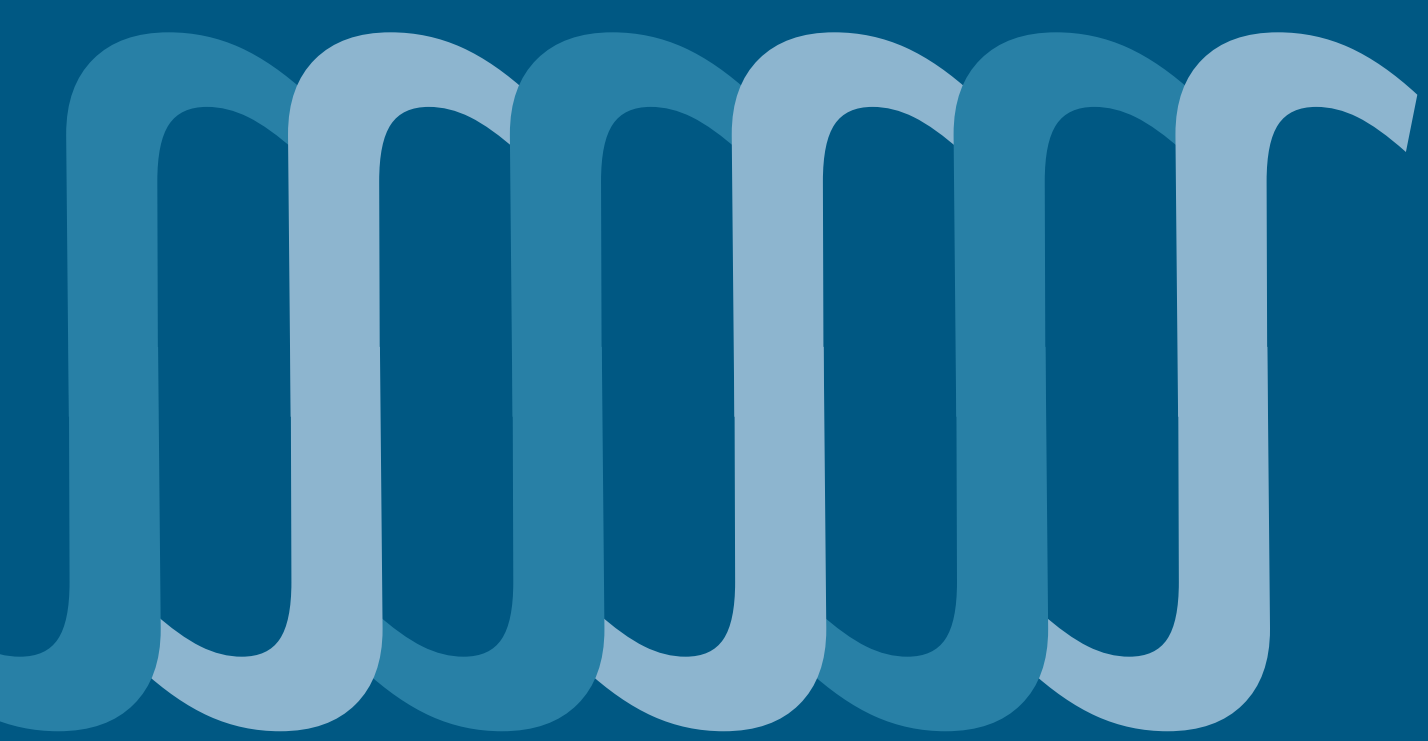

Založba Univerze na Primorskem www.hippocampus.si 